\title{
Crime and Governance in Indian Country
}

Angela R. Riley

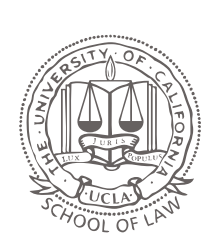

ABSTRACT

Criminal jurisdiction in Indian country is defined by a central, ironic paradox. Recent federal laws expanding tribal criminal jurisdiction are, in many respects, enormous victories for Indian country, as they acknowledge and reify a more robust notion of tribal sovereignty, one capable of accommodating increased tribal control over safety and security on Indian reservations. At the same time, the laws make clear that sovereignty comes at a price, potentially working to effectuate further assimilation of tribal courts and Indian people. As a result, at the same time that tribal sovereignty gains ground in ways critical to autonomy and self-governance, it is simultaneously threatened by exogenous forces that have the potential to homogenize tribal justice systems legally, politically, and-in particular-culturally.

This Article offers the first comprehensive assessment of the Tribal Law and Order Act and the reauthorization of the Violence Against Women Act, respectively, to show how they relate to one another on the ground and the implications for tribal sovereignty and self-determination. Ultimately, based on data compiled for the first time as well as extensive secondary sources, I argue that expanded criminal jurisdiction and punishment authority have, perhaps paradoxically, enhanced the ability of tribes to develop and enforce policies, laws, and procedures that are consistent with tribal custom and tradition. This presents a unique opportunity worthy of further exploration. In other words, rather than sovereignty and assimilation expanding in tension with one another, I find that the application of the laws has been experienced in tribal communities, as least anecdotally and preliminarily, as greatly enhancing - not threatening or destroyingtribal sovereignty and Indian cultural survival.

\section{AUTHOR}

Professor of Law, UCLA School of Law; Director, Native Nations Law and Policy Center. I extend my deep thanks first and foremost to Carole Goldberg, whose four decades as a dedicated advocate for Indian people and Indian tribes inspired the Symposium for which this Article was written. Professor Goldberg's work has changed the field of Indian law and, indeed, transformed the lives of Indian people all across the United States. I also extend my sincere appreciation to the UCLA Law Review and to the Law Review Symposium Editor, Sarah Kozal, for selecting the Symposium proposal and for brilliantly shepherding the process. The UCLA School of Law provided generous research funding. This Article greatly benefited from early conversations with Noah Zatz, as well as thoughtful comments gathered at presentations at UCLA, the University of Arizona, and Harvard Law School. Jim Anaya, Asli Bali, Stuart Banner, Devon Carbado, Ben Casey, 
Jonodev Chaudhuri, Beth Colgan, Virginia Davis, Sarah Deer, Sharon Dolovich, Ingrid Eagly, Matthew Fletcher, Jerry Gardner, James Hopkins, Sonia Katyal, Brent Leonhard, Addie Rolnick, Joe Singer, Melissa Tatum, Fred Urbina, Kevin Washburn, Rob Williams, and Bill Wood gave valuable feedback and provided important insights. I extend my gratitude to all those at Pascua Yaqui, Umatilla, and Tulalip for their devotion to tribal justice and their support of this project. Thanks to the National Congress of American Indians and the Tribal Law and Policy Institute for guiding so much of this work on the ground. Sincere appreciation to my students, Simone Anter (UCLA) and Esther Labrado (Harvard) for their outstanding research assistance and to Lindsay Cutler for her indispensable contribution. And, for Kristen Carpenter, chi-megrwetch.

\section{TABLE OF CONTENTS}

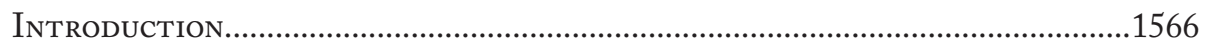

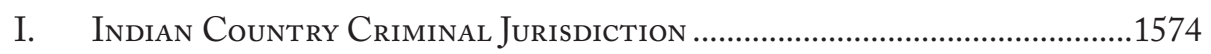

A. A Brief History..................................................................................1576

B. Recent Interventions: The 2010 Tribal Law and Order Act and the 2013 Reauthorization of the Violence Against Women Act ..................1584

1. The 2010 Tribal Law and Order Act............................................1585

2. The 2013 Reauthorization of the Violence Against Women Act..1589

II. Tribal Experiences With Expanded Criminal Authority....................1595

A. Tribal Sovereignty and Assimilation: A Fine Balance ...........................1597

B. Individual Rights in Tribal Criminal Jurisdiction ....................................1607

C. Crime and (Tribal) Punishment .........................................................1615

III. Contemplating the Future: A Theory of Indian Country Crime AND Governance .........................................................................................1619

A. Unexplored Opportunities: The Indian Nation as Criminal Justice

Laboratory .....................................................................................1622

1. Going Further: Alternatives to Incarceration.................................1624

2. Focusing on Root Causes .........................................................1628

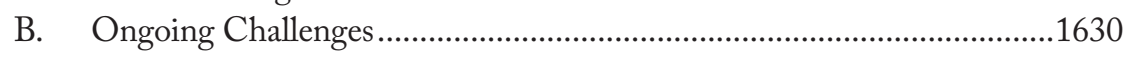

1. Holding the Federal Government Accountable............................1630

2. Clarifying Arrest Authority ........................................................1633

3. Expanding VAWA's Reach ..........................................................1635

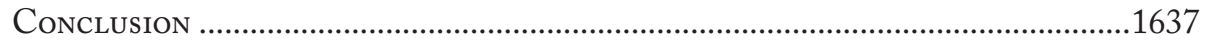




\section{INTRODUCTION}

The news reminds us daily that America is embroiled, if reluctantly, in a tense conversation about crime and race. But the anomalous, ${ }^{1}$ dire, and disheartening picture of crime in Indian country ${ }^{2}$ has remained largely outside of mainstream dialogue. Decades of isolation and indifference-much of which has been facilitated, if not created, by federal law and policy-have led to astonishingly bleak conditions in regards to safety and security on Indian reservations across the United States. ${ }^{3}$ Concerns over the current political, fiscal, and humanitarian crises around police power, mass incarceration, the war on drugs, and other efforts to "govern through crime" ${ }^{4}$ have inspired long overdue conversations about American criminal justice. ${ }^{5}$ And though scholarship in this area has highlighted the impacts of underprotection in some communities, ${ }^{6}$ there has been inadequate scholarly inquiry into the devastating consequences of the degree of neglect seen in Indian country, home to some of society's most vulnerable members. ${ }^{7}$ Thus, the situation playing out on Indian reservations all across

1. The relation of Indian tribes as preexisting sovereigns situated within the borders of the United States has always been "an anomalous one and of a complex character." United States v. Kagama, 118 U.S. 375, 381 (1886); see also Gerald L. Neuman, Anomalous Zones, 48 STAN. L. REV. 1197, 1202 n.30 (1996) (including tribes as within the "anomalous zones" of territory under the control of the United States).

2. "Indian country" is a codified term of art, which largely refers to lands colloquially referred to as "Indian reservation[s]," though it also includes many others. 18 U.S.C. § 1151 (2006).

3. When referring to the indigenous peoples of the United States, this Article uses the terms "Native American," "American Indian," and "Indian" interchangeably.

4. JONATHAN SIMON, GOVERNING THROUGH CRIME: HOW THE WAR ON CRIME TRANSFORMED AMERICAN DEMOCRACY AND CREATED A CULTURE OF FEAR 4 (2007).

5. Some leading work in the field includes, for example, MiCHELLE ALEXANDER, THE NEW JiM CROW: MASS INCARCERATION IN THE AGE OF COLORBLINDNESS (2012); PAUL BUTLER, LET'S GET FreE: A HiP-Hop TheORY OF Justice (2009); MARIE GotTSCHALK, The PRISON AND THE GALlOWS (2006); SimON, supra note 4; William J. STUNTZ, THE COllapSE OF AMERICAN CRIMINAL JuSTICE (2011); James Forman, Jr., Racial Critiques of Mass Incarceration: Beyond the New Jim Crow, 87 N.Y.U. L. REV. 21 (2012).

6. See RANDALl KenNEDY, RACE, CRIME, AND THE LAW, 29-135 (1997) (detailing how "underprotection" in law enforcement has, along with over-policing, harmed African Americans).

7. INST. OF EDUC. SCIS., STATUS AND TRENDS IN THE EDUCATION OF AMERICAN INDIANS AND ALASKA NATIVES: 2008, at 26 (2008), http://nces.ed.gov/pubs2008/2008084.pdf [https://perma.cc/LF9N-4DDF] (finding that Native Americans, especially on reservations, have disproportionately high poverty rates, rising to nearly double the national average); see also STEVEN W. Perry, Bureau of Justice Statistics, U.S. DeP’T of Justice, NCJ 203097, 
the country should be understood as inextricably related to race and police power in America, but treated as a distinct phenomenon: an abuse of power of a different variety.

The "jurisdictional maze" in Indian country — the result of a haphazard collection of federal statutes and U.S. Supreme Court cases that disaggregate tribal territorial sovereignty from criminal jurisdiction ${ }^{9}$ - has plunged Indian country into crisis. ${ }^{10}$ Generally speaking, states have no criminal jurisdiction in Indian country if either the defendant or victim is Indian. ${ }^{11}$ Thus, Indian country criminal jurisdiction is largely divided between the tribal and federal governments. But two key restrictions that were in place for decades—one imposed by the U.S. Congress, the other by the Supreme Court—have severely limited tribes' ability to provide adequate safety and security on Indian reservations. Until 2010, the Indian Civil Rights Act of 1968 limited tribal sentencing authority to a maximum of one year in jail or a fine of $\$ 1000$ per count, regardless of the crime. ${ }^{12}$

AMERICAN INDIANS AND CRIME (2004), https://www.justice.gov/sites/default/files/ otj/docs/american_indians_and_crime.pdf [https://perma.cc/42PT-2Y8K]. American Indians also face disproportionate rates of incarceration, and rates of violent crime on Indian reservations are double the national average, exceeding those of other racial groups. Id. at iv-v.

8. Robert N. Clinton, Criminal Jurisdiction Over Indian Lands: A Journey Through a Jurisdictional Maze, 18 ARIZ. L. REV. 503, 504 (1976) [hereinafter Clinton, Jurisdictional Maze] (calling tribal criminal justice a "jurisdictional maze"); Robert N. Clinton, Development of Criminal Jurisdiction Over Indian Lands: The Historical Perspective, 17 ARIZ. L. REV. 951 (1975) [hereinafter Clinton, Historical Perspective] (providing the historical background for criminal jurisdiction in Indian country).

9. See Joseph William Singer, Sovereignty and Property, 86 Nw. U. L. REV. 1, 3 (1991) (using Indian law as a framework to provide a detailed account of the complex relationship between sovereign power and property). Criminal jurisdiction over Indian country crimes is governed by a maze of shifting and sometimes contradictory variables, including where the crime was committed, whether the perpetrator is Indian, whether the victim is Indian, and even the type of crime committed, among other considerations. INDIAN LAW \& ORDER COMM'N, A ROADMAP FOR MAKING NATIVE AMERICA SAFER, at ix (2013), http://www.aisc.ucla.edu/iloc/report/files/A_Roadmap_ For_Making_Native_America_Safer-Full.pdf[https://perma.cc/3TZV-8M3F].

10. See Dennis Wagner, Whiteriver Serial Rapist Investigation Failed, Files Show, ARIZ. REPUBLIC (Sept. 12, 2010, 12:00 AM), http://www.azcentral.com/news/articles/2010/09/12/ 20100912whiteriver-arizona-apache-reservation-serial-rapist.html [https://perma.cc/2NWE2GQL] (quoting Virginia Davis, then Deputy Director for the Justice Department's Office on Violence Against Women, as noting that "[w]e're really at a crisis point in a lot of our Native American communities"); see also On Indian Reservations in the West, Violent Crime Soars, N.Y. TIMES (Aug. 16, 1998), http://www.nytimes.com/1998/08/16/us/on-indian-reservations-in-thewest-violent-crime-soars.html [https://perma.cc/W22P-R8JZ]

11. Worcester v. Georgia, 31 U.S. 515, 561-62 (1832) (holding that state criminal laws had no role in Indian country). Congress subsequently passed the General Crimes Act to deal with interracial crime in Indian country. See 18 U.S.C. $\$ 1152$ (2012).

12. 25 U.S.C. $\$ 1302(a)(7)(B)(2012)$ (limiting a tribal sentence for any conviction to one year or a fine of $\$ 5000$ or both); see also 25 U.S.C. $\$ 1302$ (b) (2012) (allowing tribes to impose longer sentences - up to three years or a fine of $\$ 15,000$ or both—in some circumstances). 
This limitation remains in effect for the vast majority of American Indian tribes. ${ }^{13}$ Additionally, the Supreme Court's 1978 case of Oliphant v. Suquamish Indian Tribe stripped tribes of criminal jurisdiction over non-Indians altogether, and has only now been slightly modified as to a small subset of crimes, which can be prosecuted by a handful of tribes. ${ }^{14}$

As a consequence of these restrictions, the federal government-except for the relatively minor legal modifications discussed in this Article ${ }^{15}$ - has exclusive jurisdiction over most crimes committed by non-Indians against Indians or Indian property in Indian country, ${ }^{16}$ as well as exclusive jurisdiction over major crimes. ${ }^{17}$ But the federal government's limited resources combined with an array of disincentives to investigate and prosecute Indian country crimes means that remarkably few are ever even superficially pursued. ${ }^{18}$

13. The original Act imposed a six-month incarceration and $\$ 500$ fine limitation, but was later amended. 25 U.S.C. $\$ 1302$ (1982)

14. See Oliphant v. Suquamish Indian Tribe, 435 U.S. 191, 212 (1978), superseded by statute in part, Department of Defense Appropriations Act of 1991, Pub. L. No. 101-511, § 8077(b)-(c), 104 Stat. 1856, 1892-93 (1990) (codified at 25 U.S.C. § 1301(2), (4)) (clarifying that Indian tribes may assert jurisdiction over nonmember Indians); $c f$. Violence Against Women Act of 1994, 42 U.S.C. $\S 13925$ (2014) (authorizing criminal jurisdiction over non-Indians in limited circumstances, as discussed herein). Some statistics indicate that non-Indians commit the vast majority of rape against Indian women, with numbers as high as 90 percent. However, not all of these data account for whether the crimes occurred within Indian country. See SARAH DEER, THE BEgINNING AND END OF RAPE: CONFRONTING SEXUAL VIOLENCE IN NATIVE AMERICA 20 (2015).

15. Cf. Act of Aug. 15, 1953, Pub. L. No. 83-280, 67 Stat. 588 (1953) (extending state criminal jurisdiction over Indian country in selected states). The mandatory Public Law 280 states are: California, Oregon (except Warm Springs), Wisconsin, Nebraska (except Menominee), and Minnesota (except Red Lake). Id. Alaska became a mandatory Public Law 280 state upon statehood.

16. General Crimes Act, 18 U.S.C. § 1152 (2012).

17. Major Crimes Act, 18 U.S.C. $\$ 1153$ (2012).

18. This is particularly true of misdemeanor offenses. Matthew L.M. Fletcher, Sovereign Comity: Factors Recognizing Tribal Court Criminal Convictions in State and Federal Courts, 45 CT. REV. 12, 15 (2009) (discussing the absence of federal prosecutions of misdemeanor crimes committed by non-Indians against Indians or Indian property); see also Letter from Ronald Weich, Assistant Attorney General, to Vice President Joseph Biden (July 21, 2011), https://www.justice.gov/ sites/default/files/tribal/legacy/2014/02/06/legislative-proposal-violence-against-native-

women.pdf [https://perma.cc/PEZ5-YN55] (noting that "[f]ederal resources, which are often the only ones that can investigate and prosecute these crimes, are often far away and stretched thin"). Even as to felonies, however, recent statistics show that federal declination rates of Indian country crimes are incredibly high. See AMNESTY INT'L, MAZE OF INJUSTICE: THE FAILURE TO PROTECT InDigenous WOMEN From SEXUAL Violence IN THE USA 27-39 (2007); Timothy Williams, Higher Crime, Fewer Charges on Indian Land, N.Y. TIMES (Feb. 20, 2012), http://www.nytimes.com/2012/02/21/us/on-indian-reservations-higher-crime-and-fewerprosecutions.html [https://perma.cc/HW79-GT6W] (noting that "federal prosecutors in 2011 declined to file charges in 52 percent of cases involving the most serious crimes committed on Indian reservations"); see also U.S. GOV'T ACCOUNTABILITY OFFICE, GAO-11-167R, DECLINATIONS OF INDIAN COUNTRY CRIMINAL MATTERS 9 (2010), http:/www.gao.gov/ 
Federal law and policy is primarily responsible for deplorable reservation conditions, where crime rates generally are more than twice the national average, and, in some places, soar to over twenty times the national average. ${ }^{19}$ Indian women fare the worst, with violence against them reaching "epidemic rates." 20 On some reservations, the murder rate of Native women is ten times the national average. ${ }^{21}$ The Department of Justice's own statistics report that the rate of violent victimization of American Indian women is more than double that among all women, ${ }^{22}$ and more than one-third of American Indian and Alaskan Native women-34 percent-will be raped in their lifetimes. ${ }^{23}$

For decades, tribal leaders and advocates lobbied Congress to relax restrictions on tribal prosecutorial and sentencing authority to address Indian country crime. And the nation's leading Indian law scholars laid the intellectual foundation for the creation of a new framework. For example, Carole Goldberg's writing on Public Law 280 provided a seminal critique regarding the costs of displacement of tribal authority in Indian country criminal justice. Perhaps more significantly, her groundbreaking work imported empirical studies into Indian country criminal jurisdiction analysis for the first time, a move that was

assets/100/97229.pdf [https://perma.cc/WZH4-C6J4] (noting that federal prosecutors declined to prosecute over two-thirds of sexual assault cases referred from Indian country). According to critics, however, sexual assault and rape are generally under-prosecuted. See generally Tyler Kingkade, Prosecutors Rarely Bring Charges in College Rape Cases, Huffington POST (June 17, 2014, 7:31 AM) http://www.huffingtonpost.com/2014/06/17/college-rape-prosecutors-presscharges_n_5500432.html [https://perma.cc/43S3-2T3R] (citing research funded by the Department of Justice stating that "[o]nly between 8 percent and 37 percent of rapes ever lead to prosecution" and "just 3 percent to 18 percent of sexual assaults lead to a conviction"). Between 1997 and 2006, federal prosecutors rejected nearly two-thirds of the reservation cases brought to them by FBI and Bureau of Indian Affairs investigators, more than twice the rejection rate for all federally prosecuted crimes. 3 TRIBAL LAW AND ORDER ACT OF 2010: A LEGISLATIVE HiSTORY OF PUBLIC LAW 111-21133, 19-20 (2012) (prepared statement of Hon. Joe A. Garcia, President, National Congress of American Indians).

19. S. REP. NO. 111-93 (2009), http://www.narf.org/nill/resources/TOLASenateReport.pdf [https://perma.cc/25YM-L85T]. "Violent crime rates in Indian country are more than twice the national average, with violent crime rates exceeding 20 times the national average on some reservations." Id. at 2.

20. Letter from Ronald Weich, Assistant Attorney General, to Vice President Joseph Biden, supra note 18. See generally DEER, supra note 14.

21. RONET BACHMAN ET AL., VIOLENCE AGAINST AMERICAN INDIAN AND ALASKA NATIVE WOMEN AND THE CRIMINAL JUSTICE RESPONSE: WHAT IS KNOWN 5 (2008), https://www.ncjrs.gov/pdffiles1/nij/grants/223691.pdf.

22. PERRY, supra note 7 , at v.

23. PATRICIA TJADEN \& NANCY ThOENNES, U.S. DEP’T OF Justice, Full REPORT OF THE PREVAlENCE, InCIDENCE, AND CONSEQUENCES OF VIOLENCE AGAINST WOMEN 22 (2000), https://www.ncjrs.gov/pdffiles1/nij/183781.pdf [https://perma.cc/L3M8-8WT9]; see also AMNESTY INT’L, supra note 18, at 27-39 (exploring the jurisdictional challenges hindering Native women's access to effective justice following sexual assault and other related crimes). 
instrumental in shaping future federal legislation in the field. ${ }^{24}$ With a series of innovative writings at the intersection of federal Indian law and criminal justice policy, Kevin Washburn constructed a frame for policymakers, in particular, to envision practical changes in tribal criminal jurisdiction. ${ }^{25}$ And activist turned scholar, Sarah Deer, broke new ground, giving voice to indigenous

24. Carole Goldberg is one of the country's leading scholars of federal Indian law and was among the first to engage in qualitative research in Indian country, particularly in regards to Public Law 280 criminal jurisdiction. See, e.g., DuAne Champagne \& CAROle GOldBerg, CAPTURED JusticE: NATIVE NATIONS AND PUBliC LAW 280 (2012); CAROLE GOLDBERG-AMBROSE, Planting TAil Feathers: Tribal Survival AND Public LaW 280 (1997) (detailing the effects of Public Law 280 on reservations and proposing reconstructive policies for tribes); INDIAN LAW \& ORDER COMM'N, supra note 9; Carole E. Goldberg, Public Law 280: The Limits of State Jurisdiction Over Reservation Indians, 22 UCLA L. REV. 535 (1975), reprinted in NATIVE AMERICANS AND THE LAW: CONTEMPORARY AND HISTORICAL PERSPECTIVES ON AMERICAN INDIAN Rights, FREEDOMS, AND SOVEREIGNTY 273 (John Wunder ed., 1996); Carole Goldberg \& Duane Champagne, Searching for an Exit: The Indian Civil Rights Act and Public Law 280, in THE INDIAN CIVIL RIGHTS ACT AT FORTY 247 (Kristen A. Carpenter, Matthew L.M. Fletcher \& Angela R. Riley eds., 2012); Carole GoldbergAmbrose, Public Law 280 and the Problem of Lawlessness in California Indian Country, 44 UCLA L. REV. 1405, 1409 (1997) (suggesting that the purported meaning of "lawlessness" on reservations as a reason for Public Law 280's enactment was a cultural construct and arguing that Public Law 280 was a source of such lawlessness rather than a remedy); Carole Goldberg \& Duane Champagne, Is Public Law 280 Fit for the Twenty-First Century? Some Data at Last, 38 CONN. L. REV. 697, 707 (2006) [hereinafter Goldberg \& Champagne, Fit for the Twenty-First Century] (finding that after the 1968 amendments, retrocession took place in more than twenty-five tribes in both mandatory and optional Public Law 280 states).

25. Kevin Washburn has been one of the leading scholarly voices for criminal justice reform in Indian country in recent years. See, e.g., U.S. Sentencing Commission: Judicial Administrative Testimony, Phoenix Regional Hearing on the 25th Anniversary of the Sentencing Reform Act (Jan. 20, 2010) (testimony of Kevin Washburn, Dean, University of New Mexico School of Law, urging the federal sentencing commission to consult with tribes about the use of tribal court convictions to evaluate a convicted defendant's criminal history); Oversight Hearing on Law Enforcement in Indian Country: Hearing Before the S. Comm. on Indian Affairs, 110th Cong. 1-3 (2007) (testimony of Byron Dorgan, Chairman, S. Comm. on Indian Affairs) (arguing for more cooperative law enforcement agreements between federal and tribal police to better police Indian reservations); Kevin K. Washburn, American Indians, Crime, and the Law, 104 MiCH. L. REV. 709 (2006) [hereinafter Washburn, American Indians] (detailing how the lack of resources in Indian country bears on criminal justice at the tribal and federal levels); Kevin K. Washburn, American Indians Crime and the Law: Five Years of Scholarship on Criminal Justice in Indian Country, 40 ARIZ. ST. L.J. 1003 (2008) [hereinafter Washburn, Five Years of Scholarship]; Kevin K. Washburn, Federal Criminal Law and Tribal Self-Determination, 84 N.C. L. REV. 779 (2006) [hereinafter Washburn, Federal Criminal Law] (arguing that more focus on tribal control and tribal self-determination will help with safety and security on Indian reservations); Kevin K. Washburn, Tribal Courts and Federal Sentencing, 36 ARIZ. ST. L.J. 403, 434 (2004) [hereinafter Washburn, Tribal Courts and Federal Sentencing] (arguing that federal Indian country trials are inconsistent with basic American norms of criminal justice, and that reform is necessary); Kevin K. Washburn, Tribal Self-Determination at the Crossroads, 38 CONN. L. REV. 777 (2006) [hereinafter Washburn, Crossroads]. 
women and the acute crisis around sexual violence. ${ }^{26}$ All of these efforts—and many others-led to the two federal statutes at the heart of this Article: the Tribal Law and Order Act of 2010 (TLOA), ${ }^{27}$ which allows tribes, under specified conditions, increased sentencing authority; and the reauthorization of the Violence Against Women Act (VAWA) in 2013, which recognizes-for the first time since 1978 - tribes' inherent criminal jurisdiction over non-Indians who commit acts of domestic violence, dating violence, or intimate partner violence against an Indian in Indian country if certain criteria are met. ${ }^{28}$ Both statutes seek to restore a modicum of tribal sovereignty over criminal justice matters in Indian country.

But criminal jurisdiction in Indian country is defined by a central, ironic paradox. Passage of these recent federal laws regarding tribal criminal jurisdiction are, in many respects, enormous victories for Indian country. The expansions in authority acknowledge and reify a more robust notion of tribal sovereignty, one capable of accommodating increased tribal control over safety and security on Indian reservations. At the same time, the laws make clear that sovereignty comes at a price, potentially working to effectuate further assimilation of tribal courts and Indian people. The U.S. Constitution does not bind tribal governments. Thus, as part of the trade-off for increased tribal criminal authority, both statutes require that tribes follow additional procedural requirements and standards that are more in line with the federal Constitution. Moreover, in some cases, federal funding is even contingent on tribes

26. Sarah Deer began laying the intellectual foundation for this work a decade ago. See, e.g., Sarah Deer, Sovereignty of the Soul: Exploring the Intersection of Rape Law Reform and Federal Indian Law, 38 SUFFOLK U. L. REV. 455 (2005) (articulating a theory of rape in colonization and subsequent federal control of Native peoples); Sarah Deer, Toward an Indigenous Jurisprudence of Rape, 14 KAN. J.L. \& PUB. POL'Y 121 (2004) [hereinafter, Deer, Toward an Indigenous Jurisprudence] (grounding the rape and sexual assault of Native women in a larger colonial context of conquest and dispossession). She was recently awarded a MacArthur Genius Grant for her advocacy work regarding VAWA. Mary Hudetz, 'We're Not Done': MacArthur Fellow Sarah Deer Finds Justice for Native American Victims of Violence, WASH. POST (Sept. 22, 2014), https://www.washingtonpost. $\mathrm{com} / \mathrm{blogs} / \mathrm{she}$-the-people/wp/2014/09/22/were-not-done-macarthur-fellow-sarah-deer-findsjustice-for-native-american-victims-of-violence/ [https://perma.cc/6F2N-WF46].

27. Tribal Law and Order Act of 2010, Pub. L. No. 111-211, 124 Stat. 2258, 2280 (2010).

28. 25 U.S.C. $\$ 1304$ et seq. (2012 \& Supp. 2014). For a thorough discussion of some of the privacy implications of singling out domestic violence offenses for particular treatment within criminal law, see JEANNIE SuK, AT HOME IN THE LAW: HOW THE DOMESTIC VIOLENCE REVOLUTION Is TRANSFORMING PRIVACY 19 (2009) (describing, among other things, how the imposition of domestic violence protection orders "opens up a range of conduct in the home to criminal law control"). 
implementing an American carceral model. ${ }^{29}$ As a result, at the same time that tribal sovereignty gains ground in ways critical to autonomy and selfgovernance, it is simultaneously threatened by exogenous forces, which themselves have the potential to homogenize tribal justice systems legally, politically, and-in particular-culturally.

As the first scholar to obtain the files from all of the tribal court VAWA prosecutions during the statutorily defined pilot project window, I draw on these case files, as well as extensive secondary sources and aggregated data, to describe the implementation of the two statutes in Indian country thus far. ${ }^{30}$ Thus, this Article offers the first comprehensive assessment of these newly enacted statutes, how they relate to one another on the ground, and their implications for tribal sovereignty and self-determination. This analysis leads to two central claimsspeaking to doctrine and theory, respectively_and ultimately advances a normative proposal for an indigenous approach to Indian country criminal justice moving forward. First, I conclude that implementation has been a success in several respects. Tribes have provided defendants with the requisite procedural protections, and the preliminary data reveal that the laws are improving the safety and security of reservation residents. In addition, despite legitimate fears that implementation of these federal statutes serves as another form of cultural

29. For example, under the TLOA, tribes may be able to house inmates in federal custody at federal expense. 25 U.S.C. $§ 1302(d)(1)(B)$ (2012). But nothing in the statute allocates federal funding for a comparable program that would constitute an alternative to incarceration.

30. A note on methodology and the limitations of data available in this research: This Article examines TLOA prosecutions from the time of its passage on July 29, 2010 until the close of the VAWA pilot project on March 6, 2015. There is no granular data on TLOA prosecutions, and the tribes have neither identified nor catalogued the TLOA cases. So the analysis relies almost entirely on secondary sources. These sources indicate there were approximately thirty to forty TLOA prosecutions during the relevant period. It is clear that the Confederated Tribes of the Umatilla Indian Reservation (CTUIR) became TLOA compliant in 2011 and handed down the first extended sentence under TLOA in November 2012. VAWA was reauthorized on March 7,2013, and the Pilot Project commenced February 6, 2014. The VAWA Pilot Project ended March 6, 2015. During that time, only five pilot project tribes were certified to undertake special domestic violence jurisdiction (SDVCJ) over non-Indians: the Confederated Tribes of the Umatilla Reservation in Oregon, the Tulalip Tribes in Washington, and Pascua Yaqui in Arizona. Fort Peck Assiniboine and Sioux Tribes in Montana and Sisseton-Wahpeton Oyate in South Dakota were designated as pilot project tribes only one day before the conclusion of the pilot project, and, therefore, had no opportunity to file any cases under VAWA. Thus, the relevant time frame for VAWA prosecutions studied herein is from March 7, 2013 until March 6, 2015, during which time there were twenty-eight VAWA cases involving twenty-four offenders. NAT'L CONG. OF AM. Indians, SPECIAL DOMESTIC VIOLENCE CRIMINAL JuRISDICTION PILOT PROJECT REPORT 5 (2015), http://www.ncai.org/attachments/NewsArticle_VutTUSYSfGPRpZ QRYzWcuLekuVNeeTAOBBwGyvkWYwPRUJOioqI_SDVCJ\%20Pilot\%20Project\%20Repo rt_6-7-16_Final.pdf. To undertake this study, I have procured from the three prosecuting VAWA tribes every available case file from the VAWA prosecutions that occurred in the pilot project window. 
assimilation into tribal communities ${ }^{31}$ the initial research reveals that the application of the laws has been experienced in tribal communities, at least anecdotally and preliminarily, as greatly enhancing-not threatening or destroying-tribal sovereignty and Indian cultural survival. ${ }^{32}$

Building off the doctrinal and theoretical analyses of the impact of the statutory changes, this Article proceeds to advance a normative recommendation. I argue that expanded criminal jurisdiction and punishment authority have, perhaps paradoxically, enhanced the ability of tribes to develop and enforce policies, laws, and procedures that are consistent with tribal custom and tradition, and this presents a unique opportunity worthy of further exploration. In other words, rather than sovereignty and assimilation expanding in tension with one another, I find that the strengthening of sovereignty simultaneously enhances the ability of tribes to further protect traditional tribal values and indigenous justice systems. I seek to urge tribes even further in that direction, to view this enhanced tribal criminal authority as presenting an opportunity to only selectively engage the American system of criminal justice, and to deviate from it, when possible, in favor of experimenting more thoughtfully with indigenous methods of justice and restoration. ${ }^{33}$

Certainly, advancing these two lines of thought in parallel - it is good for tribal sovereignty when tribes exercise their federally expanded criminal authority and, at the same time, tribes should consider deviating as far from the American model of criminal justice as is feasible when executing that authoritycomplicates the message of this work. However, I argue that this point of tension is reconcilable both on pragmatic and theoretical grounds. Practically speaking, the current system of criminal justice in Indian country is untenable. The cost to

31. Lorelei Laird, Indian Tribes Are Retaking Jurisdiction Over Domestic Violence on Their Own Land, A.B.A. J. (Apr. 1, 2015, 6:02 AM), http://www.abajournal.com/magazine/article/indian_tribes_ are_retaking_jurisdiction_over_domestic_violence_on_their_own $\quad[\mathrm{https} / / / \mathrm{perma} . c c / \mathrm{G} 9 \mathrm{FR}-$ $\mathrm{SM} 3 \mathrm{~B}]$.

32. It is important to reiterate that it is too early to draw broad-based conclusions based on the limited data available, including the very small sample size of cases.

33. I note from the outset there are many instances, including sexual abuse, rape, and others, that may be inappropriate for a traditional proceeding because it cannot adequately protect the rights of victims. Deer, Toward an Indigenous Jurisprudence, supra note 26, at 124-36; see also Carole E. Goldberg, Overextended Borrowing: Tribal Peacemaking Applied in Non-Indian Disputes, 72 WASH. L. REV. 1003 (1997) (cautioning against using traditional dispute resolution practices in the absence of factors that make it protective of victims and effective for defendants); Martha Minow, Between Vengeance and Forgiveness: Feminist Responses to Violent Injustice, 32 NEW ENG. L. REV. 967, 974 (1998) (remarking that "feminists are more likely to express concerns about mediation in the context of violence and abuse than to endorse it"); Laird, supra note 31 (noting that the President of the NCAI stated that some domestic violence cases would be inappropriate for a traditional proceeding, and "I don't think anybody's looking to use a wellness court for a severe spousal abuse case"). 
Indian people and Indian women, in particular, is staggering. Where tribes can utilize expanded authority to provide improved access to justice for tribal members-even where it involves modeling the American carceral state-they should consider doing so. At the same time, looking further down the road, tribes have a unique opportunity to build off their own sovereignty to experiment more thoughtfully with Indian country criminal justice in ways that may, ironically, enhance their ability to reject the American model in favor of reclaiming some aspects of restorative, indigenous justice systems in the future.

This Article proceeds as follows. Part I provides a succinct but comprehensive look at tribal criminal jurisdiction historically, including Congress' recent passage of both TLOA and VAWA. Specifically, it addresses some of the consequences of what happens when criminal jurisdiction is disaggregated from geography, and when the racial and political identity of the parties involved become key features in assigning responsibility for safety and security in Indian country. Part II then analyzes the individual case files and secondary materials concerning the tribal prosecutions to highlight the central tension in Indian country criminal jurisdiction thematically, as: implicating the tension between tribal sovereignty and assimilation; balancing individual versus collective rights within the tribal criminal justice system; and contemplating tribal punishments when lawbreakers are punished. Finally, Part III takes on the broader, normative questions that arise from the preceding inquiry to make one central claim: that a move toward adoption of both TLOA and VAWA, respectively, where politically and fiscally feasible, provides an opportunity for tribal governments to exercise, enhance, and enrich tribal sovereignty, and that such an exercise of sovereignty has the potential to bolster the legitimacy and vitality of tribes as nations. At the same time, I urge tribes to embrace the unique opportunity to experiment with criminal justice systems that may not only be better suited to their communities, but that may also stand as a model for state and federal governments moving forward.

\section{INDIAN COUNTRY CRIMINALJURISDICTION}

The criminal justice crisis that exists in Indian country today is a manifestation of a failure of law so extreme that it has actually caused reservation crime to flourish. Pursuant to the common law, criminal jurisdiction is typically grounded in geography. ${ }^{34}$ That is, the sovereign asserts criminal jurisdiction over those who

34. T. Alexander Aleinikoff, Semblances of Sovereignty: The Constitution, the STATE, AND AMERICAN CITIZENSHIP (2002); see Sarah H. Cleveland, Powers Inherent in Sovereignty: Indians, Aliens, Territories, and the Nineteenth Century Origins of Plenary Power Over 
commit crimes within its territory ${ }^{35}$ as determined by the location or "situs" within which the crime was committed. ${ }^{36}$ But this basic understanding of sovereignty was flipped on its head in Indian country. Pursuant to a series of federal interventions motivated both by beliefs in the racial inferiority of Indians and the concomitant desire to assimilate them into White society, criminal jurisdiction in Indian country was disaggregated from territory. And the remaining gaps in criminal jurisdiction left exclusively under the authority of the federal government have never been adequately filled. The bizarre result is that criminal jurisdiction over Indian country crimes is governed by shifting and sometimes contradictory variables, including where the crime was committed, whether both the defendant and victim are Indians, ${ }^{37}$ and the classification of the alleged crime, among other considerations. ${ }^{38}$

In the following Parts I.A and I.B, I give a brief account of this history of Indian country criminal jurisdiction, as well as some detail regarding the two statutes at the core of this Article. What this history demonstrates is that Indian country criminal justice is a story of piecemeal interventions-both by Congress and the Supreme Court—-that have created the "maze" within which reservation

Foreign Affairs, 81 TEX. L. REV. 1, 4 (2002) (arguing that "[a] member of the community of nations was considered to exercise complete sovereignty within its territorial jurisdiction and external sovereignty only (if at all) with respect to its own citizens"); see also Allison M. Dussias, Geographically-Based and Membership-Based Views of Indian Tribal Sovereignty: The Supreme Court's Changing Vision, 55 U. PITT. L. REV. 1, 37-38 (1993); of. KAL RAUSTIALA, DOES THE CONSTITUTION FOLLOW THE FLAG? THE EVOLUTION OF TERRITORIALITY IN AMERICAN LAW 233 (2009) (defining "intraterritoriality" as the U.S. policy of treating some internal sovereigns distinctly in constitutional terms).

35. See LEA BRILMAYER, AN INTRODUCTION TO JURISDICTION IN THE AMERICAN FEDERAL SYSTEM 323 (1986).

36. See 4 WaYne R. LAFAVE ET AL., CRIMINAL Procedure $§ 16.4($ b) (4th ed. 2015) ("Under that [traditional common law] limitation, crimes typically have but one situs, and, in the absence of a statute overriding the limitation by establishing jurisdiction over crimes only partly committed within its territorial boundaries, the sovereign has jurisdiction only when the particular conduct constituting the common law situs occurred within its territory.").

37. This system of determining jurisdiction adds to existing complexities. The vast majority of reservations are home to Indians of various categories: some are tribal members of the tribe on whose reservation they reside, some are members of other tribes, and still others are Indian for some purposes under federal law, but may not be for purposes of tribal prosecution. Circuits are currently split over how to define "Indian" for purposes of federal criminal jurisdiction. See also Addie C. Rolnick, Tribal Criminal Jurisdiction Beyond Citizenship and Blood, 39 AM. INDIAN L. REV. 337 (2016). Compare United States v. Cruz, 554 F.3d 840, 846 (9th Cir. 2009), with United States v. Dodge, 538 F.2d 770, 786-87 (8th Cir. 1976) (noting that courts consider "recognition by a tribe or society of Indians or by the federal government"). Most reservations also have some sizeable non-Indian population, with many being majority non-Indian. L. Scott Gould, The Congressional Response to Duro v. Reina: Compromising Sovereignty and the Constitution, 28 U.C. DAVIS L. REV. 53, 134 tbl.4 (1994) (detailing that, in eight of the ten most populated reservations, the majority of residents were non-Indian).

38. INDIAN LAW \& ORDER COMM'N, supra note 9, at viii. 
Indians find themselves today, with devastating consequences. The question that remains is whether the two recent remedial statutes advance the safety and security of Indian people, or, rather, simply further the assimilation of American Indian communities and justice systems without sufficient, corresponding benefits to Indian nations.

\section{A. A Brief History}

Criminal jurisdiction is of such primary concern to a sovereign that, within the American system, for example, the perpetration of a crime is considered not only to be committed against the victim, but against the sovereign itself. ${ }^{39}$ Thus, the state assumes the responsibility of seeking justice as an exercise of its sovereignty. ${ }^{40}$ And the state, through its own system of governance, sets up parameters for sentencing and punishment, subject to constitutional constraints.

Like other sovereigns, Indian tribes are deeply concerned with jurisdiction over crime within their territory. The push and pull between sovereigns around issues of criminal jurisdiction evidence the importance attached to exercises of sovereign authority through incarceration and other forms of punishment. ${ }^{41}$ In fact, one of the earliest Indian law cases ever to reach the Supreme Court, Worcester v. Georgia, ${ }^{42}$ involved a criminal prosecution by the state of Georgia against a missionary who entered Cherokee territory with the permission of the tribal government but without a permit from the state of Georgia. ${ }^{43}$ The $\mathrm{Su}-$ preme Court held then - as it still holds today — that state criminal laws generally do not apply in Indian country. ${ }^{44}$ Over the years, tribes — oftentimes with the support of the federal government-have carefully guarded Indian country as being specifically within the domain of the tribes and, in many instances, the federal government. But, ever importantly, this power was always exercised at the exclusion of the state. ${ }^{45}$

39. Dussias, supra note 34 .

40. See Cleveland, supra note 34 , at 4.

41. James T. Meggesto, At a Crossroads: Promises and Puzzles for Tribal-State Relations After VAWA 2013, in EMERGING IsSUES IN TRIBAL-STATE RELATIONS: LEADING LAWYERS ON ANALYZING THE ECONOMIC, CULTURAL, AND POLITICAL TRENDS AFFECTING TRIBALSTATE INTERACTIONS 101 (2014).

42. Worcester v. Georgia, 31 U.S. 515 (1832).

43. Id. at 561-62 (holding that state criminal laws had no role in Indian country). Congress subsequently passed the General Crimes Act to deal with interracial crime in Indian country. See 18 U.S.C. $\$ 1152$ (2012).

44. See Worcester, 31 U.S. at 515; see also infra notes 54-56 and accompanying text; $c f$. Act of Aug. 15, 1953, Pub. L. No. 83-280, § 1162, 67 Stat. 588, 588 (1953).

45. See Meggesto, supra note 41, at 101-10. 
In the pre-contact era criminal jurisdiction was handled internally accordingto tribal customary law. ${ }^{46}$ But, after European contact, conflict between Indians and settlers slowly introduced federal jurisdiction into Indian country criminal justice matters. By the late 1700 s, some treaties between the tribes and the federal government selectively allowed for shared criminal governance between the tribes and the United States for certain interracial crimes. ${ }^{47}$ It was understood that the federal government had a specific federal interest in preventing violent crime involving Indians and settlers. In keeping with this shared vision as pertaining to interracial crimes, Congress passed the General Crimes Act in 1817, which extended the general penal laws of the federal government to Indian country. ${ }^{48}$ The Act excluded wholly internal crimes (Indian on Indian), and situations where Indians commit offenses against non-Indians, but that have already been punished by the tribe. ${ }^{49}$ Tribes then, and now, maintain exclusive jurisdiction over misdemeanor crimes involving only Indians.

This arrangement excluded the states entirely, as it has historically been - and largely still is today - the baseline presumption that states have no jurisdiction in Indian country. This arrangement of shared federal-tribal jurisdiction - at the exclusion of the state-remained for one hundred years until the Supreme Court decided United States v. McBratney ${ }^{50}$ in 1881, holding that the state had exclusive jurisdiction over a crime committed by a non-Indian against a non-Indian in Indian country. ${ }^{51}$ McBratney introduced a rare and unusual premise- that states could have a role in Indian country jurisdiction-but maintained the ever-important rule that states had no jurisdiction in any situation involving an Indian (as perpetrator or victim)..$^{52}$

Shortly following McBratney, Congress again passed legislation dealing with Indian country criminal jurisdiction. The resulting statute, the Major Crimes Act, ${ }^{53}$ was enacted in response to a murder by one Indian (Crow Dog) of another (Spotted Tail) within Indian country. The tribe imposed a restorative

46. See generally KARL N. LlEWELlyn \& E. AdAMSON Hoebel, The CheYEnNE WAY: CONFLICT AND CASE LAW IN PRIMITIVE JURISPRUDENCE (1987).

47. See Ex parte Crow Dog, 109 U.S. 556, 568 (1883) (citing Treaty of Hopewell, Nov. 28, 1785, 7 Stat. 18); Washburn, Federal Criminal Law, supra note 25, at 792.

48. See 18 U.S.C. $§ 1152(2012)$.

49. Id.

50. United States v. McBratney, 104 U.S. 621 (1881).

51. See id. at 624.

52. See id. (holding that the state has exclusive jurisdiction with regards to non-Indian on non-Indian crime). But cf. Worcester v. Georgia, 31 U.S. 515, 561-62 (1832) (holding that state laws have no effect in Indian country).

53. Major Crimes Act, 18 U.S.C. $§ 1153$ (2012). 
punishment, requiring that Crow Dog's family offer an apology, money, blankets, and horses to the family of Spotted Tail. The exchange was made, and the dispute was settled internally. ${ }^{54}$ The Supreme Court agreed that the matter was best left to the tribe to resolve. ${ }^{55}$ But Indian agents working for the federal government purportedly used the case as an opportunity to stir up sentiment regarding "savage" Indians who had let Crow Dog murder without real punishment. ${ }^{56}$ Within two years, Congress responded. In a move expressly intended to break up traditional tribal justice systems and further the assimilation of Indians into White society, Congress passed the 1885 Major Crimes Act. It extended federal jurisdiction to enumerated major crimes committed by an Indian in Indian country, whether the victim is Indian or non-Indian. ${ }^{57}$

The history briefly recounted leads to a few baseline presumptions about the role of federal and state law, respectively, in Indian country. Except for selectively applied federal laws, ${ }^{58}$ Indian country is free from state criminal jurisdiction when an Indian is involved in the crime as either the victim or the perpetrator. ${ }^{59}$ Accordingly, the federal government maintains its historic and continued role as a significant player in ensuring criminal justice in Indian country. Absent treaty provisions to the contrary, federal criminal laws of general applicability apply in Indian country to all people just as they apply elsewhere. ${ }^{60}$ The federal government also has jurisdiction over crimes committed in Indian country by a nonIndian against an Indian ${ }^{61}$ and over major crimes committed by an Indian, whether the victim is Indian or non-Indian. ${ }^{62}$

The parameters of tribal criminal jurisdiction in the United States, by contrast, have been set largely by the U.S. Supreme Court, though congressional acts certainly have clarified and shaped it. ${ }^{63}$ Long before the Constitution was drafted and ratified, Indian nations had inherent sovereignty over their people and territories and governed according to their own laws. ${ }^{64}$ Indian tribes were

54. See generally GOLDBERG ET AL., AMERICAN INDIAN LAW: NATIVE NATIONS AND THE FEDERAL SYSTEM (7th ed. 2015).

55. See Exparte Crow Dog, 109 U.S. 556, 568 (1883).

56. See SiDNEY L. HARring, CROW DOG'S CASE: AMERICAN INDIAN SOVEREIGNTY, TRIBAL LAW, AND UNITED STATES LAW IN THE NINETEENTH CENTURY 10 (1994).

57. See 18 U.S.C. $\$ 1153$ (2012); see also United States v. Kagama, 118 U.S. 375, 384-85 (1886).

58. Act of Aug. 15, 1953, Pub. L. No. 83-280, 67 Stat. 588 (1953).

59. See 18U.S.C. §1152 (2012)

60. See Fed. Power Comm'n v. Tuscarora Indian Nation, 362 U.S. 99, 116 (1960).

61. See 18U.S.C. §1152 (2012). But see the discussion of Public Law 280, supra note 24.

62. See 18 U.S.C. $\$ 1153$ (2012).

63. See Matthew L.M. Fletcher, Tribal Consent, 8 STAN. J. C.R. \& C.L. 45, 100 (2012) (noting that the Supreme Court has set tribal criminal jurisdiction, "with some Justices conveying open hostility to congressional preferences").

64. Angela R. Riley, Indians and Guns, 100 GEO. L.J. 1675, 1718-21 (2012). 
never formally brought within the U.S. Constitution. ${ }^{65}$ Thus, the Constitution, which has never been amended to incorporate tribal governments into the federal-state system, does not bind Indian tribal governments. ${ }^{66}$ Nevertheless, tribes are subject to the plenary authority of Congress, which has largely upheld federal efforts to set the scope of tribal sovereignty in matters of criminal jurisdiction. ${ }^{67}$

As discussed more fully in Part II.B, the adversarial criminal justice system of prosecutions, trials, and incarceration seen today in most tribes that maintain a criminal court is a distinctly Western model that was imposed onto tribes in the nineteenth century, ${ }^{68}$ specifically to disrupt and destroy tribal cultures, ${ }^{69} \mathrm{In}$ dian justice systems, ${ }^{70}$ and traditional dispute resolution practices. ${ }^{71}$ Tribes reluctantly operated under the federal model forced upon them for over one hundred years. Such was the state of affairs in Indian country criminal justice when hearings began in the 1960s regarding the inapplicability of the U.S. Constitution's Bill of Rights to Indian tribal governments, a conversation

65. Nor were these features incorporated via the Fourteenth Amendment. See Talton v. Mayes, 163 U.S. 376, 383-84 (1896) (establishing that the U.S. Bill of Rights was not extended to tribes through the Fourteenth Amendment).

66. See Cherokee Nation v. Georgia, 30 U.S. 1, 18, 20 (1831). The U.S. Constitution's protections were extended to individual Indians when they became American citizens in 1924, but the Constitution still does not apply to Indian nations. Some scholars have argued that the federal government acquiesces in tribes' extraconstitutional authority, which may create conditions potentially justifying broader application of the Bill of Rights to tribal governments. See Zachary S. Price, Dividing Sovereignty in Tribal and Territorial Criminal Jurisdiction, 113 COLUM. L. REV. 657, 723 (2013) (arguing for a "pragmatic approach" to application of the Bill of Rights to tribal governments); Noah Feldman, The Theorists' Constitution—And Ours, 117 HARV. L. REV. 1163, 1174-75, n.25 (2004) (book review) (arguing that the fact that tribes are not seen as "instrumentalities" of the federal government, and that they "constitute separate quasisovereignties," is a "legal fiction").

67. See U.S. CONST. art. I, $\S 8$, cl. 3 (enumerating the power of Congress to "regulate commerce ... with the Indian Tribes").

68. See Barbara L. Creel, The Right to Counsel for Indians Accused of Crime: A Tribal and Congressional Imperative, 18 MiCH.J. RACE \&L. 317, 320-21 (2013).

69. See WiLliam T. HAGAN, INDIAN POLICE AND JUDGES: EXPERIMENTS IN ACCULTURATION AND CONTROL 69-70 (1966) (noting that Indians were urged to police the reservation for the federal government, and an initial mandatory concession was to require that they defy their religion and cut off their braids).

70. See, e.g., Ex parte Crow Dog, 109 U.S. 556, 571 (1883).

71. For several in-depth treatments of historical tribal dispute resolution practices, see, for example, ANGIE DEBO, THE RISE AND FALL OF THE CHOCTAW REPUBLIC (1961); LLEWELLYN \& HoEBEL, supra note 46, at 20-40; JOHN PHILlIP REID, A LAW OF BLOOD: THE PRIMITIVE LAW OF THE CHEROKEE NATION 201-15 (1970); RENNARD STRICKLAND, FiRE AND THE SPIRITS: CHEROKEE LAW FROM CLAN TO COURT 130-57 (1975); ERNEST WALLACE \& E. ADAMSON HoEbEL, THE COMANCHES: LORDS OF THE SOUTH PlaINS 209-44 (1976); Ken Traisman, Note, Native Law: Law and Order Among Eighteenth-Century Cherokee, Great Plains, Central Prairie, and Woodland Indians, 9 AM. INDIAN L. REV. 273 (1981). 
raised, in part, by tribal members' complaints about the absence of constitutional protections in tribal criminal proceedings. ${ }^{72}$ The hearings ultimately resulted in congressional action, manifesting in the Indian Civil Rights Act of 1968 (ICRA), which sets forth rights guaranteed to individual Indians vis-à-vis tribal governments. These protections map onto, but are certainly not coterminous with, the protections afforded under the U.S. Constitution's Bill of Rights, as Congress' goal was to balance individual rights with the federal policy of tribal self-determination. ${ }^{73}$ Though many of the protections guaranteed in the criminal process are present, including the writ of habeas corpus, ${ }^{74}$ the protections are not identical, and tribal courts have significant leeway in interpretation and application of the statute. ${ }^{75}$ In this selective application bill, Congress declined to extend to tribes the requirement of grand jury indictment, jury trials in civil cases, ${ }^{76}$ and the right to paid counsel for indigent defendants. ${ }^{77}$

72. See Indian Civil Rights Act of 1968, Pub. L. No. 90-284, 82 Stat. 77 (codified as amended at 25 U.S.C. § 1302 (2000)); Santa Clara Pueblo v. Martinez, 436 U.S. 49, 61 (1978) (quoting S. REP. No. 90-841, at 5-6 (1967)) ("[A] central purpose of the ICRA . . was to 'secur[e] for the American Indian the broad constitutional rights afforded to other Americans,' and thereby to 'protect individual Indians from arbitrary and unjust actions of tribal governments."').

73. See Santa Clara Pueblo v. Martinez, 436 U.S. 49, 62 n.11 (1978) (noting the balance struck by ICRA). For a critique of Santa Clara Pueblo's preferencing of tribal sovereignty over individual rights, see, for example, AMY GUTMANN, IDENTITY IN DEMOCRACY 47 (2004) (arguing with regard to Santa Clara Pueblo that "group sovereignty often amounts to a license for the dominant members of a group to impose injustice on others"). But see Gloria Valencia-Weber, Rina Swentzell \& Eva Petoskey, 40 Years of the Indian Civil Rights Act: Indigenous Women's Reflections, in THE INDIAN CIVIL RigHTS ACT AT FORTY 39 (Kristen A. Carpenter, Matthew L.M. Fletcher, \& Angela R. Riley eds., 2012) (stating that, as an indigenous woman, Eva Petoskey would pay the price of individual rights for her tribe's sovereignty and autonomy).

74. See 25 U.S.C. $\$ 1303$ (2012) ("The privilege of the writ of habeas corpus shall be available to any person, in a court of the United States, to test the legality of his detention by order of an Indian tribe.”); 114 CONG. REC. 5518, 5520 (Mar. 6, 1968); see also Santa Clara Pueblo, 436 U.S. at 62 n.11 (1978) (noting that President Johnson supported ICRA on the ground that it furthered "selfdetermination," "self-help," and "self-development" within Indian nations).

75. See Santa Clara Pueblo, 436 U.S. at 65 (holding that there is no federal court review of trial court decisions regarding ICRA claims except through the writ of habeas corpus).

76. See Constitutional Rights of the American Indian: Hearing on S. Res. 53 Before the Subcomm. on Constitutional Rights, S. Comm. on the Judiciary, 87th Cong. (1961) [hereinafter 1961 Hearing]; see also ALVIN J. ZIONTZ, A LAWYER IN INDIAN COUNTRY 173 (2009) (discussing the outcome of the U.S. Senate hearings on Indian rights); Alvin J. Ziontz, In Defense of Tribal Sovereignty: An Analysis of Judicial Error in Construction of the Indian Civil Rights Act, 20 S.D. L. REV. 1, 5 (1975) (citing Constitutional Rights of the American Indian: Hearing on S. 961, S. 962, S. 963, S. 964, S. 965, S. 966, S. 967, S. 968, and S.J. Res. 40 Before the Subcomm. on Constitutional Rights, S. Comm. on the Judiciary, 89th Cong. 64-65 (1965) (statement of Arthur Lazarus, Jr., General Counsel, Association on American Indian Affairs, Inc.)).

77. See 25 U.S.C. $§ 1302($ c) (2012); Constitutional Rights of the American Indian: Hearing on S. 961, S. 962, S. 963, S. 964, S. 965, S. 966, S. 967, S. 968, and S.J. Res. 40 Before the Subcomm. on Constitutional Rights, S. Comm. on the Judiciary, 89th Cong. 131 (1965) [hereinafter 1965 Hearing] 
ICRA also set the stage for the debates decades later around the Tribal Law and Order Act, as ICRA initially limited punishments to six months in prison or $\$ 500$ per count. Congress amended ICRA in 1986 to expand tribes' sentencing authority from six months to one year per count and a $\$ 5000$ monetary fine, but still did not authorize felony sentencing. ${ }^{78}$

Notably, Congress's revision of the ICRA came after the 1978 Supreme Court decision of Oliphant v. Suquamish Indian Tribe, wherein the Court held that Indian tribes do not have criminal jurisdiction over non-Indians. ${ }^{79}$ The Court's decision in Oliphant caused enormous concern for tribes and Indian law scholars, as Indian country is the only place within the United States where the racial and political status of the perpetrator and victim bear on the question of which sovereign may exercise jurisdiction in a given instance. ${ }^{80}$ As this history has shown, Indian country criminal jurisdiction is bizarrely disaggregated from geography. The standard understanding is that the sovereign within which the crime was committed has jurisdiction over the crime, and the sovereign may prosecute the person who commits a crime within its borders. ${ }^{81}$ By turning this presumption on its head in Indian country, Indian tribes lost a core prerogative of the sovereign, losing the right to punish the non-Indian offender, even when he commits a crime against an Indian. Thus, where "[n]o other sovereign has as great an interest in trying individuals for breaches of the peace as does the sovereign in whose territory the offense occurred," Indian tribes are set adrift. ${ }^{82}$

As a result, after the passage of ICRA, limiting tribal court criminal sentences, and the Supreme Court's decision in Oliphant, excluding non-Indians

(statement of Marvin J. Sonosky) (“[T]ribes generally do not have the funds to pay for all inclusive features of S. 961. . . . Jury trials, prosecutors, appeals courts, counsel for indigents, all cost money.").

78. See Indian Civil Rights Act of 1968, Pub. L. No. 90-284, §§ 201-203, 82 Stat. 73, 77-78 (1968) (codified as amended at 25 U.S.C. $§ \S 1301-1303$ (2006)).

79. See Oliphant v. Suquamish Indian Tribe, 435 U.S. 191, 212 (1978), superseded by statute in part, Department of Defense Appropriations Act of 1991, Pub. L. No. 101-511, § 8077(b)-(c), 104 Stat. 1856, 1892-93 (1990) (codified at 25 U.S.C. §1301(2), (4)).

80. See, e.g., WALTER R. ECHO-HAWK, IN THE COURTS OF THE CONQUEROR: THE 10 WORST INDIAN LAW CASES EVER DECIDED 21 (2010) (saying cases like Oliphant, which reflect "the vestiges of colonialism . . . must go"); Robert N. Clinton, There Is No Federal Supremacy Clause for Indian Tribes, 34 ARIZ. ST. L.J. 113, 214 (2002) (stating that Oliphant's reasoning is "an inventive process of judicial historical revisionism"); Deer, Toward an Indigenous Jurisprudence, supra note 26, at 128 (contending that Oliphant puts "tribal communities at the mercy of non-Indian criminals"); Philip P. Frickey, (Native) American Exceptionalism in Federal Public Law, 119 HARV. L. REV. 431, 457-58 (2005) (calling Oliphant's reasoning "troubling"); Joseph William Singer, Canons of Conquest: The Supreme Court's Attack on Tribal Sovereignty, 37 NEW ENG. L. REV. 641, 650 (2003) (asserting that the Supreme Court's decision in Oliphant is an attack on tribal sovereignty).

81. See, e.g., Cleveland, supra note 34, at 44.

82. Dussias, supra note 34, at 37-38. 
from tribal criminal jurisdiction, stories of injustice have poured out of Indian country. ${ }^{83}$ Just in the past few years, testimony given before Congress has revealed countless incidences of inadequate punishments, failures to prosecute, paltry resources for safety and policing, as well as brazen acts of violence by savvy criminals actively seeking to commit crimes on reservations where they believe they are insulated from prosecution. ${ }^{84}$ In some documented cases, perpetrators even called the tribal police themselves, knowing there would not be a response, arrest, or prosecution. ${ }^{85}$ Studies show that countless Indian women and girls decline to even report violent crime or sexual assault committed by non-Indians on the reservation because they do not believe there will be justice. ${ }^{86}$ Thus, the field

83. See, e.g., Christine Folsom-SMith, EnHANCED SENTENCING IN TRIBAL CourTS: LESSONS LEARNED FROM TRIBES 9 (2015), https:/www.bja.gov/Publications/TLOATribalCtsSentencing.pdf [https://perma.cc/ZNY9-KTND] (noting that women of Hopi spoke to the community and to tribal leaders about unprosecuted crimes against women in particular and the resulting injustices to sway their decision); Laird, supra note 31; Michael Riley, 1885 Law at Root of Jurisdictional Jumble, DENVER POST (Nov. 11, 2007, 1:00 AM) [hereinafter Riley, 1885 Law at Root], www.denverpost.com/lawlesslands/ci_7422829 [https://perma.cc/7ET6-E43T]; Michael Riley, Path to Justice Unclear, DENVER POST (Nov. 14, 2007, 1:00 AM) [hereinafter Riley, Path to Justice Unclear], http://www.denverpost.com/ci_7454999 [https://perma.cc/P4X6SMHX].

84. See generally Discussion Draft Legislation to Address Law and Order in Indian Country: Hearing Before the S. Comm. on Indian Affairs, 110th Cong. 1 (2008) [hereinafter 2008 Hearing] (statement of Hon. Byron L. Dorgan, U.S. Sen.) ("[There is] established longstanding and life-threatening public safety crises that exist on some Indian reservations... . [S] exual and domestic violence have reached epidemic proportions; victims have to wait in many cases hours and weeks for a response to law enforcement calls .... The lack of consequences has created some notion of lawlessness in many communities."); see also 160 CONG. REC. 26, S942 (discussing the Violence Against Women Act: "Over the years, what happened is that white men, non-native men, would go onto a Native American reservation and go hunting - rape, abuse and even murder a native woman, and there's absolutely nothing anyone could do to them,' said Kimberly Norris Guerrero, an actress, tribal advocate and native Oklahoman who is Cherokee and Colville Indian. "They got off scot-free."); AMNESTY INT'L, supra note 18, at 33 (alteration in original) (quoting Jodi Rave, South Dakota Tribal-City Police Department a National Model for Handling Domestic Abuse, THE MissoULIAN (Sept. 24, 2006), http://missoulian.com/jodirave/domestic-violence-south-dakota-tribal-citypolice-department-a-national/article_ca9be598-0339-57e0-a042-a70d0310188c.html

[https://perma.cc/NJ46-BXXP]) ("[N]on-Native perpetrators often seek out a reservation place because they know they can inflict violence without much happening to them."); INDIAN LAW \& ORDER COMM'N, supra note 9, at 110 (quoting Indian Law E' Order Comm'n, Hearing on Tribal Law and Order Act 3 (Jan. 13, 2012) (testimony of Edward Reina, Jr., Director of Public Safety, Tohono O'odham Nation), https://www.indianlawandordercommission.com/resources/ documents/ILOCFH_PhxAZ_Testimony_EReina.pdf [https://perma.cc/9WZU-2HNH]) ("Tribal offenders realize that they can travel from one Tribal community to another to hide, commit crime link [sic] with other offender's [sic] without being concerned about being identified as a criminal offender.").

85. Laird, supra note 31.

86. Laird, supra note 31 (quoting Brent Leonhard, attorney with the Office of Legal Counsel for the Confederated Tribes of the Umatilla Indian Reservation, finding that interviews indicated that "[w] here the partner was non-Indian, we found that over 80 percent chose not to go to the police"); 
is replete with accounts of rapists, serial batterers, and murderers that are either never prosecuted at all for their crimes, or that are only prosecuted by tribal governments, which for decades could only impose a maximum sentence of one year incarceration per offense, no matter how serious the crime. ${ }^{87}$

The consequences for tribal sovereignty and self-determination have been immense. Of the 4.6 million people living in Indian country in 2010, 3.5 million were non-Indians who could not be prosecuted by tribal governments. ${ }^{88}$ The cost of these policies has been seen and felt throughout all of Indian country for decades, with the most severe shortcomings experienced by Indian women and children. ${ }^{89}$ Without basic public safety, communities deteriorate: Students cannot focus on learning; tribes and individual tribal members cannot engage in economic development, attract business, or grow tourism..$^{90}$ Tribal members lose faith in tribal governments as well as in the federal system. ${ }^{91}$ By depriving tribes of the localized community control that characterizes virtually all law enforcement in the United States, federal policy itself caused the descent of Indian country into crisis. ${ }^{92}$

see also M. Brent Leonhard, Implementing VAWA 2013, 40 HUM. RTS., no. 4, 2014, at 19, http://www.americanbar.org/publications/human_rights_magazine_home/2014_vol_40/vol_ 40-no-1—tribal-sovereignty/implementing-vawa-201.html [https://perma.cc/7XFA-RDA7] (citing U.S. DEP'T OF JUSTICE, INDIAN COUNTRY INVESTIGATIONS AND PROSECUTIONS (2013), https://www.justice.gov/sites/default/files/tribal/legacy/2014/08/26/icip-rpt-cy2013.pdf [https://perma.cc/3WHS-YLGY]) (explaining the absence of reporting crime by non-Indians in Indian country: "There is a very good reason for Indian victims not to report non-Indian domestic violence in Indian country. They know that historically non-Indian domestic violence crimes went unprosecuted and unpunished. If no one gets prosecuted, a victim isn't going to report the crime. Reporting the crime in this situation will make the victims less safe, and both anger and embolden the perpetrator.").

87. See Indian Civil Rights Act of 1968, Pub. L. No. 90-284, § 901, 82 Stat. 73, $89-90$ (1968); $c f$. Seth Fortin, The Two-Tiered Program of the Tribal Law and Order Act, 61 UCLA L. REV. DISC. 88 (2013) (noting that the TLOA implicitly limits "stacking" in non-TLOA jurisdictions to nine years).

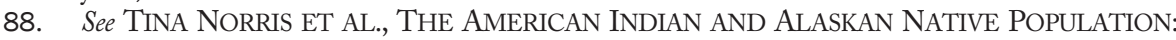
2010, at 13-14 (2012), http://www.census.gov/prod/cen2010/briefs/c2010br-10.pdf [https://perma.cc/V6FA-ZFSW].

89. See supra notes 20-23 and accompanying text (detailing rates of violent crime against Indian women and girls).

90. See 3 TRibal LAW AND ORder ACt OF 2010: A LEgislative History Of Public LAW, supra note 18 , at 53.

91. See INDIAN LAW \& ORDER COMM'N, supra note 9, at 21 (noting that, without appropriate sentencing authority, "the sentencing restrictions erode Tribal community members' and outsiders' confidence in Tribal governments' ability to maintain law and order in Indian country").

92. See Washburn, Five Years of Scholarship, supra note 25, at 1014-16 (describing law enforcement in the United States generally as a "community endeavor" and explaining how this differs in Indian country). 


\section{B. Recent Interventions: The 2010 Tribal Law and Order Act and the 2013 Reauthorization of the Violence Against Women Act}

Concerned with criminal justice in Indian country, the U.S. Senate Committee on Indian Affairs began to hold hearings in 2004. ${ }^{93}$ Advocates for Indian women, children, and others testified to put a human face on the horrifying statistics making news. Around the same time, the Denver Post ran a series of articles detailing some of the greatest criminal justice challenges facing Indian country. The articles focused on the paucity of resources for crime control, the absence of human capital, and the complex legal regime at play, all of which feed the enormity of the problem. ${ }^{94}$ Then Amnesty International released a foundational report in 2007 to explain the jurisdictional and other limits faced by Indian tribes and why these limits had disproportionately harmful impacts on Indian women. ${ }^{95}$

For decades, tribal communities had felt entirely stymied by the current political system and lack of response to the criminal justice crises on reservations. Tribal members expressed deep frustration and a sense of hopelessness around federal prosecutors' decisions to decline to prosecute the most serious crimeseven rape and murder-on the reservation. ${ }^{96}$ As Kevin Washburn has argued, such feelings of futility were wholly justified. Federal criminal justice mechanisms have essentially no political accountability to tribes. ${ }^{97}$ Federal officials rarely live in Indian country and are seldom members of the reservation community. The political, cultural, and literal distance between reservation communities and federal prosecutors has only fed the lack of trust in the system and fueled an increasing sense of illegitimacy and hopelessness in Indian country. ${ }^{98}$

Out of this convergence of media coverage, targeted advocacy, coalition building, and lobbying came the enactment of the two statutes at the core of this Article: the 2010 Tribal Law and Order Act, expanding tribes' sentencing authority in some instances, and the 2013 reauthorization of the Violence Against

93. See DEER, supra note 14 , at 99 .

94. See, e.g., Riley, 1885 Law at Root, supra note 83; Riley, Path to Justice Unclear, supra note 83. See also Washburn, American Indians, supra note 25, at 721-40 (discussing various aspects of making Indian country criminal justice so difficult).

95. AMNESTY INT'L, supra note 18.

96. See INDIAN LAW AND ORDER COMM'N, supra note 9, at 33.

97. Washburn, American Indians, supra note 25, at 731.

98. Id. at 723-24. 
Women Act, recognizing tribes' inherent sovereignty to punish all domestic violence offenders in Indian county, subject to certain restrictions. ${ }^{99}$

\section{The 2010 Tribal Law and Order Act}

The Tribal Law and Order Act (TLOA) contained numerous provisions to improve criminal justice in Indian country, but three of its statutory features were of the greatest significance: enhanced sentencing, required reporting of federal declination rates, and creation of the Indian Law and Order Commission (ILOC).

The TLOA's defining provisions allow tribes enhanced sentencing over those defendants in cases in which the tribe would already have criminal jurisdiction. ${ }^{100}$ Under the TLOA, tribes are authorized to impose enhanced punishments of up to three years and fines of up to $\$ 15,000$ where particular procedural protections are in place. ${ }^{101}$ The tribes implementing TLOA can also stack sentences for crimes, with a maximum term of nine years in prison. ${ }^{102}$ The importance of TLOA was to soften sentencing restrictions and allow tribes to address some of the disparities that occur when the federal government fails to prosecute. ${ }^{103}$ A hypothetical proposed by a federal Commission highlights this problem:

Under Federal law, the crime "assault with a dangerous weapon" comes with the penalty of up to 10 years imprisonment. Even if a Tribe (in a non-P.L. 83-280 setting) were to adopt a statute that exactly matched the Federal crime, its prosecutor could only seek a sentence of up to 1 year in jail, or under TLOA enhanced sentencing, 3 years for a single offense. To access a longer sentence, the Tribal prosecutor must refer the case for Federal prosecution. If, however,

99. Cf. Price, supra note 66, at 723 (critiquing the "inherent authority" framework and arguing, instead, for a "more pragmatic approach").

100. TLOA did not expand the criminal jurisdiction of tribal governments, declining to address the practical, if not legal, gaps left by Oliphant.

101. See generally Tribal Law \& Order Act of 2010, Pub. L. No. 111-211, §§ 201-66, 124 Stat. 2261, $2262(2010)$.

102. See 25 U.S.C. $\$ 1302(a)(7)(D)(2012)$.

103. It is worth noting that this is an issue distinct from that of other sentencing disparities. Ironically, when Indians are prosecuted for major crimes, they receive disproportionately longer sentences, because they are prosecuted federally, and not by state authorities. See, e.g., William J. Stuntz, Unequal Justice, 121 HARV. L. REV. 1969, 2027 (2008) (finding that federal sentences are "far more severe than those of most states"); see also Emily Tredeau, Tribal Control in Federal Sentencing, 99 CALIF. L. REV. 1409, 1416 (2011) (“[T]he federal criminal docket concerns mostly drug, firearm, immigration, and white-collar offenses. Within the small violent slice of the federal docket, Indians make up a huge proportion of the defendants: one quarter of murders, over 75 percent of sexual abuse cases, and about 70 percent of manslaughters."'). 
the United States Attorney does not prosecute the crime, the only option left is for the Tribe to take the case back and prosecute with the lesser, ICRA-restricted sentence. After that short time, the perpetrator would again be at large in the community, free to commit more violence. ${ }^{104}$

To exercise the enhanced sentencing authority afforded by TLOA, tribes must follow additional statutory requirements intended to more closely align tribal court proceedings with those of the federal Constitution, including: The court must be a court of record; ${ }^{105}$ the judge must be licensed to practice law; ${ }^{106}$ defense counsel must be afforded and must provide effective assistance, ${ }^{107}$ and the tribe's laws must be made publicly available. ${ }^{108}$ The writ of habeas corpus remains available for any defendant to take his or her case to a federal court to challenge a tribal court conviction. ${ }^{109}$

Against this backdrop is TLOA's concomitant objective to ensure that tribes maintain wide latitude to employ tribally based restorative justice mechanisms. The TLOA encourages tribes to use "alternatives to incarceration or correctional options as a justice system response to crime in their communities." ${ }^{110}$ Further, it

104. INDIAN LAW \&ORDER COMM'N, supra note 9 , at 21.

105. 25 U.S.C. $§ 1302$ (c)(5) (2012).

106. 25 U.S.C. $\$ 1302(\mathrm{c})(3)(2012)$.

107. 25 U.S.C. $\$ 1302(\mathrm{c})(1)(2012)$.

108. 25 U.S.C. $\S 1302(c)(4)$ (2012). TLOA also has other limitations on its application, in that enhanced sentencing can only be sought where the defendant has either (1) previously been convicted of the same or comparable offense by any jurisdiction in the United States; or (2) is being prosecuted for a felony (an offense that would be punishable by more than one year imprisonment if prosecuted by the United States or any of the states).

109. 25 U.S.C. $\$ 1303$ (2012). TLOA's enhanced sentencing is entirely optional for tribes, and as a first step to implementation, tribes must choose which crimes they would like to make eligible for extended sentencing and amend their codes and, sometimes, their constitutions. Though constitutional change can be slow and burdensome, the opportunity aligns with constitutional reform already underway in Indian country. See STEPHEN CORNELL, CATHERINE CURTIS \& MIRIAM JORGENSEN, THE CONCEPT OF GOVERNANCE AND ITS IMPLICATIONS FOR FIRST NATIONS 11 (2004), https://nnidatabase.org/db/attachments/text/JOPNAs/2004_CORNELL_ curtis_jorgensen_JOPNA_conceptofgovernance.pdf [https://perma.cc/J3R9-NTYP]; see also Duane Champagne, Remaking Tribal Constitutions: Meeting the Challenges of Tradition, Colonialism, and Globalization, in RESOURCES FOR NATION BULDING: GOVERNANCE, DEVELOPMENT, AND THE FUTURE OF AMERICAN INDIAN NATIONS 12 (Eric D. Lemont ed., 2006) (arguing that prospective constitution writers will have to draw on tribal, colonial, and American examples as well as the tribe's "unique cultural and institutional arrangements and histories"); Joseph Kalt, Constitutional Rule and the Effective Governance of Native Nations, in RESOURCES FOR NATION BUILDING: GOVERNANCE, DEVELOPMENT, AND THE FUTURE OF AMERICAN INDIAN NATIONS 192 (Eric D. Lemont ed., 2006) ("It is striking how commonly one finds constitutional reform occurring within Indian nations now well-known for their political, social, cultural, and economic success."); Angela R. Riley, Good (Native) Governance, 107 COLUM. L. REV. 1049, 1080-83 (2007) (describing constitutional reform within tribal communities).

110. FOLSOM-SMITH, supra note 83 , at 1 . 
specifies that tribes can require defendants to "serve the sentence ... in an alternative rehabilitation center of an Indian tribe; or . . to serve another alternative form of punishment, as determined by the tribal court judge pursuant to tribal law." 111

The second feature of TLOA — the requirement that the government collect and disclose data regarding the declination of prosecutions-was meant to increase political accountability and transparency between tribes and the federal government. ${ }^{112}$ As discussed previously, when a non-Indian commits a crime against an Indian in Indian country - absent a unique statutory modification-the only sovereign with jurisdictional authority is the federal government. ${ }^{113}$ This means, for example, that every crime — even misdemeanors—committed by non-Indians against Indians or Indian property in Indian country can only be prosecuted by the federal government. ${ }^{114}$ But the federal government simply does not have the time, money, or incentives to investigate and prosecute most Indian country crimes. ${ }^{115}$ Testimony around TLOA even revealed that federal prosecutors have been "punished" internally for focusing too much on Indian country crimes. ${ }^{116}$ This has led to astonishingly high declination rates, even of serious crimes, ${ }^{117}$ leaving tribal communities frustrated and without faith in the criminal justice system. ${ }^{118}$

111. 25 U.S.C. $\S \S 1302(d)(1)(D), 1302(d)(2)(2012)$.

112. See Tribal Law \& Order Act of 2010, Pub. L. No. 111-211, §212(b), 124 Stat. 2261, 2268 (2010) (requiring the Attorney General to submit an annual report to Congress explaining declination rates in Indian country and the reasons for the declination).

113. In Public Law 280 states-which include California, Nebraska (excluding Menominee), Minnesota, Wisconsin (excluding Red Lake), Oregon (excluding Warm Springs), and Alaskathe state has criminal jurisdiction in Indian country, concurrent with the tribes, as it would outside of Indian country. See Act of Aug. 15, 1953, Pub. L. No. 83-280, § 2, 67 Stat. 588, 588 (1953).

114. But see Violence Against Women Act, 42 U.S.C. $\S \S 13925-14045$ (2012).

115. As Kevin Washburn has argued, although crimes of domestic violence are incredibly important to the people in the communities where they occur, they are rather routine from an FBI special agent's perspective. Washburn, American Indians, supra note 25, at 718-20.

116. See Fletcher, supra note 18 , at 19.

117. Testimony leading up to passage of TLOA revealed that, despite the federal government having exclusive jurisdiction over felony crimes on most reservations, federal prosecutors declined to file charges in 52 percent of cases involving the most serious crimes committed in Indian country. Williams, supra note 18 ("Federal prosecutors in 2011 declined to file charges in 52 percent of cases involving the most serious crimes committed on Indian reservations, according to figures compiled by the Transactional Records Access Clearinghouse at Syracuse University, which uses the Freedom of Information Act to recover and examine federal data."). The "Justice Department ... file[d] charges in only about half of Indian Country murder investigations and turn[ed] down nearly two-thirds of sexual assault cases" in the years leading up to 2010. Id. In fiscal years 2005 to 2009 , federal prosecutors declined to prosecute 67 percent of sexual abuse and related matters and declined to prosecute 46 percent of assault matters. AMNESTY INT'L, supra note 18, at 27-39; see also U.S. GOV'T ACCOUNTABILITY OFFICE, supra note 18, at 9 (noting that federal prosecutors declined to prosecute over two-thirds of sexual assault cases referred from Indian country).

118. See Michael Riley, Justice: Inaction's Fatal Price, DEnVER PosT (Nov. 12, 2007, 1:00 AM), http://www.denverpost.com;ci_7437278 [https://perma.cc/FP7V-4ALL] (noting the Montana 
Thus, TLOA has had perhaps its greatest success in requiring the federal government to be more transparent with respect to declination rates. Reports show that the mandatory disclosure requirement has significantly improved declination rates since passage of the Act. The first report released under TLOA found that U.S. attorneys "had prosecuted about 69 percent of the 3,145 criminal cases referred to their offices from Indian country [in 2012] — an improvement over 2011, when the federal government tried 63 percent of 2,840 criminal cases in Indian country." ${ }^{119}$ Since that time, declination rates have continued to fall. Tribal lawyers say there has been a "sea change in the way U.S. Attorneys interact with tribal nations" since passage of the Tribal Law and Order Act. ${ }^{120}$

The third critical feature of the TLOA was to establish the Indian Law and Order Commission (ILOC), which was charged with developing a comprehensive study of the criminal justice system relating to Indian country. The Commission's mission was broad, focusing on: examining the impact of criminal jurisdiction over Indian country crimes; the tribal and federal systems of incarceration of Indians; the state of Indian juvenile justice; and the effect of ICRA on tribes and tribal governments. In addition, the TLOA required concrete proposals from the ILOC to improve criminal justice in Indian country. ${ }^{121}$ The ILOC's work resulted in the publication of Roadmap to Justice, the most comprehensive report on Indian country criminal justice ever produced. ${ }^{122}$

U.S. Attorney's view that the "lack of investigation of low-priority felonies erodes faith in justice on reservations").

119. Timothy Williams, U.S. Says It Pursues More Prosecutions on Indian Lands, N.Y. TIMES (May 31, 2013), http://www.nytimes.com/2013/06/01/us/justice-dept-reports-rise-in-prosecutions-onindian-lands.html [https://perma.cc/QNZ6-RXK3]; see also Tribal Law \& Order Act of 2010, Pub. L. No. 111-211, § 212, 124 Stat. 2261, 2268 (2010) (requiring disposition reports). One drawback is that the TLOA does not require the federal government to identify declinations according to the type of crime, so the information now coming in is aggregated and does not specify, for example, numbers for declinations regarding violent crime.

120. See Leonhard, supra note 86, at 19 (citing U.S. DEP'T OF JUSTICE, INDIAN COUNTRY INVESTIGATIONS AND PROSECUTIONS (2013), https://www.justice.gov/sites/default/files/ tribal/legacy/2014/08/26/icip-rpt-cy2013.pdf [https://perma.cc/3WHS-YLGY]). Historical statistics are not available for declination rates of non-Indian crimes, so there is not a viable comparison point.

121. See INDIAN LAW AND ORDER COMM'N, supra note 9, at i (seeking recommendations for improvements related to: simplifying jurisdiction; improving services to Indian youth in Indian country and those incarcerated; tribal penal authority as well as alternatives to incarceration; and protecting rights of victims and defendants in tribal court, among others).

122. Beyond just expanding tribal sentencing authority, the TLOA also sought to: make federal agencies more accountable; provide greater freedom for tribes to design and run their own justice systems; enhance cooperation in law enforcement, interoperability, and access to criminal justice information; enhance funding for tribal justice systems; enhance federal cooperation and accountability; and establish the Indian Law and Order Commission to further study crime and criminal justice in Indian country. Pursuant to a four-year pilot program, tribes could also petition 
Roadmap's ultimate recommendation - the Grand Bargain-advocates, first and foremost, for tribally led solutions to end the epidemic of crime in Indian country.

\section{The 2013 Reauthorization of the Violence Against Women Act}

In those years following TLOA, forces aligned. The ILOC's Roadmap highlighted some of the most egregious instances of criminal justice failures on reservations. Lobbying efforts continued for a partial Oliphant fix, at least in regards to some crimes disproportionately suffered by Native women at the hands of non-Native men, like domestic violence. ${ }^{123}$ The 2007 Amnesty International Report again highlighted the jurisdictional and institutional barriers-many of which were attributed to federal government neglect - that made Indian women particularly vulnerable to sexually violent crimes with little access to adequate justice systems. ${ }^{124}$ The federal government's own statistics made clear that Indian people generally and Indian women in particular experienced violence at alarming rates. ${ }^{125}$ Individual tribes also began tracking their own statistics, particularly with respect to domestic violence. ${ }^{126}$ Such examinations often revealed

the Bureau of Prisons to house offenders in a federal prison at the Bureau's expense. Additionally, it allows U.S. Attorneys to appoint tribal prosecutors as Special Assistant U.S. Attorneys (SAUSAs) to prosecute reservation crimes in federal court. See Tribal Law and Order Act of 2010, Pub. L. No. 111-211, § 103(a), 124 Stat. 2261 (2010).

123. For an examination of the expansion of domestic violence laws generally, and the impact on privacy within the home, see SUK, supra note 28; Jeannie Suk, Criminal Law Comes Home, 116 YALE L.J. 2 (2006). According to the Justice Department's own statistics, in at least 86 percent of the reported cases of rape or sexual assault of American Indian and Alaska Native women-both on and off reservation-victims reported that their attackers were non-Indian. 160 CONG. REC. 26, S941 (Feb. 12, 2014) (statement of Sen. Leahy). Not all the statistics involving crime against Native women are specific to Indian country, however. And this has been the source of some efforts to discredit the need for the tribal provisions in VAWA. For a discussion of this history, see DEER, supra note 14 , at 6-9.

124. See AMNESTY INT'L, supra note 18, at 27-39 (exploring the jurisdictional challenges hindering Native women's access to justice following sexual assault and related crimes).

125. See PERRY, supra note 7 .

126. Leonhard, supra note 86, at 19-20 (citing U.S. DEP'T OF JUSTICE, INDIAN COUNTRY INVESTIGATIONS AND PROSECUTIONS (2013), https:/www.justice.gov/sites/default/files/tribal/ legacy/2014/08/26/icip-rpt-cy2013.pdf [https://perma.cc/3WHS-YLGY]). Individual tribes began tracking some of their experiences with domestic violence as well. The Confederated Tribes of the Umatilla Indian Reservation (CTUIR) reported that "[i]n 2011, the CTUIR Family Violence Program saw 43 victims of domestic violence. In 35 of these cases, we know the race of the perpetrator, and 10 of them were non-Indian. This meant that 29 percent of domestic violence perpetrators at CTUIR in 2011 were non-Indian, and the statistics were even worse in 2012. In that year, 61 percent of reported domestic violence incidents at CTUIR involved non-Indian perpetrators. CTUIR is a highly mixed reservation, with a population of around 46 percent nonIndians living on the reservation, out of a total of around 3200 residents." Id. 
a significant percentage of domestic violence cases on reservations committed by non-Indians on Indian victims. ${ }^{127}$ Beyond law and politics, passion for the reauthorization of VAWA with tribal provisions was inspired by the very personal and disturbing stories that came from Indian country about the abuse of Native women. ${ }^{128}$ As Indian law scholar and activist Sarah Deer recounts, one pivotal moment came in 2012 when the Vice Chairwoman of the Tulalip Tribes, Deborah Parker, spoke out at a press conference about her own experiences as a survival of sexual violence. Her remarks went viral, ultimately attracting thousands of views on YouTube, beginning a cascade of Native women's personal narratives about interracial violence they had experienced. ${ }^{129}$

And Parker was not alone. For those working in Indian country, Diane Millich's now familiar story powerfully highlighted the jurisdictional void in Indian country that left Indian people - and Indian women, in particularvulnerable to sexual and domestic violence. ${ }^{130}$ At age twenty-six Millich married a white man, and the couple moved to her home on the Southern Ute reservation in Colorado. Shortly after they were married, he began beating her. During repeated bouts of violence, Millich called tribal police and county sheriffs, but to no avail. Because her husband was non-Indian, the southern Ute Tribal Police had no jurisdiction over him; because she was a Native American on tribal land, the La Plata County sheriff deputies had no jurisdiction either. ${ }^{131}$ In this "jurisdictional black hole" only federal law enforcement officials could prosecute the perpetrator, and Millich's pleas for help went

127. Id.

128. See generally Sari Horwitz, New Law Offers Protection to Abused Native American Women, WASH. POST (Feb. 8, 2014), https:/www.washingtonpost.com/world/national-security/new-law-offersa-sliver-of-protection-to-abused-native-american-women/2014/02/08/0466d1ae-8f73-11e384e1-27626c5ef5fb_story.html [https://perma.cc/E8AB-DZVQ] (detailing stories of Native women abused and raped by non-Native men who could not be prosecuted by tribes and who often went without prosecution altogether).

129. See DEER, supra note 14, at 102-03.

130. See generally Jonathan Weisman, Measure to Protect Women Stuck on Tribal Land Issue, N.Y. TIMES (Feb. 10, 2013), http://www.nytimes.com/2013/02/11/us/politics/violence-against-women-actheld-up-by-tribal-land-issue.html?pagewanted=1\&_r=1\&ref=politics $\quad[\mathrm{https} / / \mathrm{perma.cc} / 87 \mathrm{MG}-$ B7MB].

131. Id. As discussed more fully in Part III.B, the issue of murky arrest authority continues to plague safety in reservation communities. As Thomas Perrelli, former associate attorney general and a chief proponent of the reauthorization, noted during hearings on the reauthorization of VAWA, on some reservations there is a question about which sovereign has the authority to intervene. In others, the state has jurisdiction but does nothing. In yet others, the federal government has jurisdiction but authorities are hundreds of miles away and "can take hours or days [...] to respond to allegations, if they respond at all.” 160 CONG. REC. 26, S940-43 (Feb. 12, 2014) (statement of Sen. Leahy). 
nowhere. ${ }^{132}$ Millich has recounted that, "[a]fter one beating, my ex-husband called the tribal police and the sheriffs department himself, just to show me that no one could stop him." ${ }^{33}$ Eventually, he stormed into her workplace with a gun and shot her coworker, who took a bullet to the shoulder to save her life. ${ }^{134}$ The perpetrator was only arrested after investigators "use[d] a tape measure to sort out jurisdiction, gauging the distance between the barrel of the gun and the point of bullet impact to persuade the local police to intervene." 135

In the face of these startling facts, Congress reauthorized the Violence Against Women Act in 2013 with tribal provisions, providing the partial Oliphant fix advocates had sought. ${ }^{136}$ VAWA affirms the inherent sovereign authority of tribes to exercise special domestic violence criminal jurisdiction over non-Indians who commit acts of domestic violence or dating violence that occur in the Indian country of the participating tribe, ${ }^{137}$ as long as the perpetrator has sufficient ties to the prosecuting tribe. ${ }^{138}$ VAWA also clarifies tribes' sovereign power to issue and enforce civil protection orders that are violated in the Indian country of the participating tribe. ${ }^{139}$ Notably, as discussed more fully in Part III.C, its limitations leave tribes without jurisdiction to prosecute collateral

132. Weisman, supra note 130.

133. Laird, supra note 31 .

134. Id.

135. Weisman, supra note 130 . Her husband pled guilty to driving with a revoked license, and was serving his sentence as of May 2012. The prosecutor did not prosecute him for domestic violence because domestic violence could only be charged as a misdemeanor in the first instance, and there was no record of his previous domestic assaults because none were prosecuted. Serena Marshall, Battered Indian Tribal Women Caught in Legal Limbo, ABC NEWs (May 17, 2012), http://abcnews.go.com/Politics/battered-indian-tribal-women-caught-legallimbo/story?id=16365091 [https://perma.cc/882Y-5QBK].

136. Initially, three tribes were authorized for the pilot project program through their applications: Pascua Yaqui (Arizona); Confederated Tribes of the Umatilla Indian Reservation (Oregon); Tulalip Tribes (Washington). One day before the completion of the pilot program, two additional tribes received authorization, but did not have time to initiate prosecutions under VAWA: Fort Peck Assiniboine and Sioux Tribes (Montana) and Sisseton-Wahpeton Oyate (South Dakota). See generally NAT'L CONG. OF AM. INDIANS, supra note 30.

137. 25 U.S.C. 1304(b)(4) (2012). The defendant must have "ties to the Indian tribe" as well, either because the defendant: resides in the Indian country of the participating tribe; is employed in Indian country of the participating tribe; or is a current or former spouse, intimate partner, or dating partner of a member of the participating tribe, or an Indian who resides in the Indian country of the participating tribe. $I d$.

138. The defendant must: reside in the Indian country of the participating tribes; be employed in the Indian country of the participating tribe; or be a spouse, intimate partner, or dating partner of a tribal member, or an Indian who resides in the Indian country of the participating tribe.

139. 25 U.S.C. § 1304(c)(2) (2012). See Violence Against Women Act (VAWA) Reauthorization 2013, U.S. DEP'T JUST., https://www.justice.gov/tribal/violence-against-women-act-vawa-reauthoriz ation-2013-0 [https://perma.cc/UG3W-JVWD] (last updated Mar. 26, 2015). 
crimes that often occur in the scope of a domestic violence complaint, such as child or elder abuse, and also excludes "stranger" sexual assault and rape. ${ }^{140}$

As with TLOA, VAWA puts into place more protections for criminal defendants in tribal courts than were required previously. If any period of incarceration is to be imposed, VAWA mandates all the same requirements of the TLOA. But it adds some additional requirements as well. To assert special domestic violence criminal jurisdiction (SDVCJ), the tribe must revise its codes to allow for a cross-section of the community to serve on juries, and the tribe must not specifically exclude any group of people (including non-Indians). And, although the right to habeas relief is available under the ICRA already, ${ }^{141}$ VAWA requires that a defendant be "timely" notified of their right to file the habeas petition and also allows the defendant to petition for a stay of the court proceedings pending outcome on the habeas petition. ${ }^{142}$

In keeping with mandates of TLOA and tribal law, VAWA guarantees the rights of tribes to impose traditional punishments in tribal court proceedings and allows tribes to seek federal funding to support such programs. As with TLOA, this remained a core feature of the statutory modification, as tribes have continued to emphasize that, where appropriate, culturally suitable punishments are preferable to incarceration. In its language, VAWA authorizes:

(f) ... grants to the governments of Indian tribes (or to authorized designees of those governments) -

(1) to strengthen tribal criminal justice systems to assist Indian tribes in exercising special domestic violence criminal jurisdiction, including-

$\cdots$

(F) alternative rehabilitation centers;

140. See Tribal LaW \& Policy Inst., Tribal Legal Code Resource: Tribal LaWs IMPLEMENTING TLOA ENHANCED SENTENCING AND VAWA ENHANCEDJURISDICTION 34 (2015), http://www.tribal-institute.org/download/codes/TLOA_VAWA_3-9-15.pdf [https://perma.cc/MR35-NWDM] (noting that "[t]he definition of dating violence seems to eliminate hookups or casual sexual relationships. Sexual assault and stalking are covered if the activity meets the definition of domestic violence or dating violence"); see also Rolnick, supra note 37 (critiquing a view of criminal jurisdiction as occurring through consent); Violence Against Women Act (VAWA) Reauthorization 2013, supra note 139.

141. 25 U.S.C. $\$ 1304(\mathrm{e})(2012)$.

142. ICRA includes a writ of habeas corpus as a primary function to get into federal court. Santa Clara Pueblo v. Martinez, 436 U.S. 49 (1978). However, some tribal lawyers cannot practice in federal court, so they cannot bring the cases or appeals. Thus, there are higher standards regarding habeas under VAWA to prevent some of these complaints. See Letter from Nat'l Ass'n of Criminal Def. Lawyers \& Nat'l Ass'n of Fed. Defs., to U.S. Senators Harry Reid, Mitch McConnell, Patrick Leahy \& Charles Grassley 15 (Apr. 23, 2012), https:/www.nacdl.org/WorkArea/DownloadAsset .aspx?id=24053\&libID=24022 [https://perma.cc/WZ68-L7KT]. 
(G) culturally appropriate services and assistance for victims and their families ...."143

The following chart, compiled and made publicly available by the Tribal Law and Policy Institute, shows a comparison of the protections required by the TLOA and VAWA, respectively. ${ }^{144}$

\section{TABLE1: TLPI Comparison Chart ${ }^{145}$}

\begin{tabular}{|l|c|c|}
\hline \multicolumn{1}{|c|}{ TLOA and VAWA Due Process Requirements } & TLOA & VAWA \\
\hline $\begin{array}{l}\text { Defendants are provided with effective assistance of counsel equal } \\
\text { to at least that guaranteed in the U.S. Constitution. }{ }^{146}\end{array}$ & $\mathrm{X}$ & $\mathrm{X}$ \\
\hline $\begin{array}{l}\text { Tribal government provides to an indigent defendant a defense at- } \\
\text { torney licensed to practice by any jurisdiction in the United } \\
\text { States. }{ }^{147}\end{array}$ & $\mathrm{X}$ & $\mathrm{X}$ \\
\hline $\begin{array}{l}\text { Defense attorney is licensed by a jurisdiction that applies appropri- } \\
\text { ate licensing standards and effectively ensures the competence and } \\
\text { professional responsibility of its licensed attorneys. }{ }^{18}\end{array}$ & $\mathrm{X}$ & $\mathrm{X}$ \\
\hline $\begin{array}{l}\text { Judges presiding over criminal proceedings subject to enhanced } \\
\text { sentencing/non-Indian defendants have sufficient legal training to } \\
\text { preside over criminal trials. }{ }^{149}\end{array}$ & $\mathrm{X}$ & $\mathrm{X}$ \\
\hline $\begin{array}{l}\text { Any judge presiding over criminal proceedings subject to enhanced } \\
\text { sentencing/non-Indian defendants is licensed to practice law by } \\
\text { any jurisdiction in the United States. }{ }^{150}\end{array}$ & $\mathrm{X}$ & $\mathrm{X}$ \\
\hline $\begin{array}{l}\text { The tribe's criminal law, rules of evidence, and rules of criminal } \\
\text { procedure are made available to the public prior to charging the de- } \\
\text { fendant. }\end{array}$ & $\mathrm{X}$ & $\mathrm{X}$ \\
\hline $\begin{array}{l}\text { Tribal court maintains a record of the criminal proceeding, includ- } \\
\text { ing an audio or other recording. }\end{array}$ & $\mathrm{X}$ & $\mathrm{X}$ \\
\hline
\end{tabular}

143. Violence Against Women Reauthorization Act of 2013, 25 U.S.C. $§ 1304$ (2012).

144. TRIBAL LAW \& POLICY INST., supra note 140, at 17-18.

145. See 25 U.S.C. $\$ 1302$ (2012) (amending ICRA pursuant to the Tribal Law and Order Act); 25 U.S.C. $\$ 1304$ (2012) (amending ICRA pursuant to the Reauthorization of VAWA).

146. 25 U.S.C. $§ 1304(\mathrm{~d})(2)$ (noting that the standard is required under VAWA only if a term of imprisonment may be imposed).

147. Id.

148. Id.

149. Id.

150. Id. 


\begin{tabular}{|l|c|c|}
\hline $\begin{array}{l}\text { Any defendant sentenced under either Act is sentenced to a facility } \\
\text { that passes the Bureau of Indian Affairs (BIA) jail standards for } \\
\text { enhanced sentencing authority. }\end{array}$ & X & X \\
\hline $\begin{array}{l}\text { Tribal court provides the defendant the right to a trial by an impar- } \\
\text { tial jury. }\end{array}$ & $\mathrm{X}$ & $\mathrm{X}$ \\
\hline $\begin{array}{l}\text { Tribal court ensures that the jury reflects a fair cross-section of the } \\
\text { community. }\end{array}$ & $\mathrm{X}$ \\
\hline $\begin{array}{l}\text { Tribal court ensures that juries are drawn from sources that do not } \\
\text { systematically exclude any distinctive group in the community, in- } \\
\text { cluding non-Indians. }\end{array}$ & $\mathrm{X}$ \\
\hline $\begin{array}{l}\text { Tribal court ensures that anyone detained under SDVCJ is "timely } \\
\text { notified" of his/her rights and responsibilities. }\end{array}$ & $\mathrm{X}$ \\
\hline $\begin{array}{l}\text { Tribal court ensures that a defendant is notified of his/her right to } \\
\text { file "a petition for a writ of habeas corpus in a court of the United } \\
\text { States." }\end{array}$ & $\mathrm{X}$ \\
\hline $\begin{array}{l}\text { Tribal court ensures that "all other rights whose protection is nec- } \\
\text { essary under the Constitution of the United States in order for } \\
\text { Congress to recognize and affirm the inherent power of the partic- } \\
\text { ipating tribe to exercise special domestic violence criminal jurisdic- } \\
\text { tion over the defendant" are provided.151 }\end{array}$ & $\mathrm{X}$ \\
\hline $\begin{array}{l}\text { Tribal court ensures that "all applicable rights under the special } \\
\text { domestic violence criminal jurisdiction provisions" are provided. }\end{array}$ & $\mathrm{X}$ \\
\hline
\end{tabular}

151. Although there was some discussion and debate about this provision of the statute, its scope and content was not clarified prior to passage of the Act. See, e.g., 4 CONG. REC. S614 (daily ed. Feb. 4,2013 ) (expressing concern that the provision would not be enough to ensure defendants all of the due process rights available under the Constitution); 5 CONG. REC. 23 (2013) (arguing that the provision was unclear as written and should be clarified). 


\section{TRIBALEXPERIENCES WITHEXPANDED CRIMINAL AUTHORITY ${ }^{152}$}

By most accounts, TLOA and VAWA stand as enormous victories for Indian country. After decades of deteriorating public safety and decreased faith in tribal and federal justice systems, the two statutes signal a remarkable directional shift in favor of tribal sovereignty. This, in turn, has empowered tribal leaders and tribal communities to take action on the ground where the scourge of crime and violence has become the hallmark of some reservations.

At the same time, the laws also present a paradox. With increased authority comes greater federal interference and more oversight into internal tribal institutions and processes. By imposing new standards on tribes-standards which closely align with those of the federal constitution, to which the tribes are not otherwise bound ${ }^{153}$ - the laws draw tribes ever closer to an American model of criminal justice and, concomitantly, potentially further away from distinct, tribal practices that are rooted in Indian difference. ${ }^{154}$ This raises the concern that Indian tribes may only be able to guarantee their sovereign rights to exercise criminal jurisdiction if they do so on the terms of the very government that has, for so long, sought to dismantle tribal justice systems. This is the double bind of tribal sovereignty. To achieve external legitimacy, tribes must often emulate the American system or be considered "too far afield from prevailing notions of American constitutionalism to be tolerable." 155 At the same time, if tribes fully transform tribal institutions, rooted in distinct tribal custom and Indian culture, the process of colonization will be complete. Given this dilemma, it has been apparent since the debates on the statutes began that increased authority could, ironically, come at the cost of sovereignty. ${ }^{156}$

152. At this point, it is unclear precisely how many TLOA prosecutions there were during the relevant time frame - from the Act's passage until the conclusion of the VAWA pilot project window-but a preliminary investigation puts the number at around thirty to forty. FOLSOM-SMITH, supra note 83, at 10 (noting that at Salt River Mariposa Pima Indian Community ten to fifteen people had been prosecuted under TLOA by June 2013, and Hopi had tried ten to fifteen people under TLOA during the same time frame; Tulalip filed twenty-three cases by August 2014). There were a total of twenty-eight VAWA arrests during the pilot period, involving twenty-four offenders. NAT’L CONG. OF AM. INDIANS, supra note 30; see also NAT’L CONG. OF AM. INDIANS, PASCUA YAQUI TRIBE VAWA IMPLEMENTATION (2015).

153. Talton v. Mayes, 163 U.S. 376, 384 (1896).

154. See Charles F. Wilkinson, American Indians, Time, and the LaW: Native SOCIETIES IN A MODERN CONSTITUTIONAL DEMOCRACY 14 (1987) (coining the phrase "measured separatism" to refer to desire of tribes to continue to live apart from White society and to maintain cultural and political difference).

155. See Kristen A. Carpenter \& Angela R. Riley, Indigenous Peoples and the Jurisgenerative Moment in Human Rights, 102 CALIF. L. REV. 173, 203 (2014).

156. Sovereignty for Indian tribes is not only understood as the role and scope of governmental authority, but also the ability of tribes to continue their unique existence as culturally distinct from 
This Part relies extensively on case files, secondary sources and aggregate data, to draw some preliminary conclusions about the impact TLOA and VAWA, respectively, have had and will continue to have in Indian country. ${ }^{157}$ The inquiry focuses both on the practical concerns implicated by application of the laws, as well as the larger, theoretical questions essential to this inquiry. In doing so, this Part explicates three particular themes raised by examining the prosecutions to date: the balance between tribal sovereignty and assimilation; the tension between collective and individual rights in tribal communities; and the role of punishment in Indian country criminal justice.

These findings may be relevant to the many considerations tribes must weigh in deciding whether to put in the time and investment to become TLOA or VAWA compliant, as well as whether to advocate nationally for legislation to increase tribal court authority in criminal matters. For some tribes-particularly those that do not already have criminal courts in place, have very small reservation populations to draw from for human capital, or have limited funds with overwhelming social problems requiring their scant resources-implementation may not be feasible or even desirable. ${ }^{158}$

the mainstream society. See generally Wallace Coffey \& Rebecca Tsosie, Rethinking the Tribal Sovereignty Doctrine: Cultural Sovereignty and the Collective Future of Indian Nations, 12 STAN. L. \& POL'Y REV. 191 (2001) (arguing for a more robust vision of sovereignty, one that looks "within" Indian tribes to what makes them culturally distinct).

157. The degree of federal oversight as contrasted between the two statutes also accounts, in part, for the varying extent to which information about implementation has been made available to the public. Moreover, in terms of implementation, the statutes are situated dissimilarly in some important respects. TLOA jurisdiction was available to all tribes as of the date of its passage on July 29, 2010. However, TLOA's due process requirements as well as the need for tribes to redefine crimes subject to felony-level sentencing meant there was a significant ramp up period, even for tribes with well-funded and well-developed legal systems. VAWA, by contrast, was only available during the period under review in this Article to a select subgroup of tribes, as authorized by the Department of Justice.

158. To predict how many tribes will realistically implement these two laws, an understanding of Indian nation demographics and various modifications to existing statutory frameworks is helpful. Of the three hundred plus tribal governments in the lower forty-eight states, 52 percent are located in Public Law 280 states, which was cut out of federal funding that went to tribes for institutionbuilding and development; thus, they tend to be ill-suited currently to adopt TLOA or VAWA. Goldberg \& Champagne, Fit for the Twenty-First Century, supra note 24, at 697 (reporting findings from a comprehensive study of the impacts of Public Law 280). The remaining 239 tribes are organized as Native Villages in Alaska. Id. Since the Supreme Court's ruling in Alaska v. Native Village of Venetie Tribal Gov't, 522 U.S. 520 (1998), the United States recognizes only Metlakatla and a few restricted trust allotments as Indian country in the state of Alaska. Accordingly, despite amendments to the reauthorization of VAWA to include the state of Alaska, village governments have relatively limited authority outside of Metlakatla. However, a federal district court has recently upheld the authority of the Secretary of Interior to take land into trust for Alaska Native villages, which could potentially positively impact the villages. Akiachak 
Building on the work of scholars and practitioners in the field, as well as accounts from tribal officials working in Indian country, this Article shows how a move towards adoption of both TLOA and VAWA, respectively, where politically and fiscally feasible, provides an opportunity for tribal governments to exercise, enhance, and enrich tribal sovereignty, and that such an exercise of sovereignty goes to the legitimacy and vitality of tribes as nations. Contrary to some assumptions about the risks of assimilation, thus far it appears that the expansion of criminal jurisdiction for tribes enhances-rather than impedes or usurps - the cultural, political, and legal fabric of tribal life that allows tribal nations to continue to thrive as distinct sovereigns within the larger polity.

\section{A. Tribal Sovereignty and Assimilation: A Fine Balance}

Protection of the people from crime is one of the core functions of government. Without safety, individuals cannot flourish, seek education or pursue other life goals. ${ }^{159}$ The tribes implementing both TLOA and VAWA, respectively-during the pilot project and since-have continuously emphasized the importance of criminal authority to tribal sovereignty, which includes the legal and moral obligation to protect tribal citizens. ${ }^{160}$ The power to play a peacekeeping role within the community, which may include incarceration, is one of the key distinguishing features of a sovereign. ${ }^{161}$ Given the state of crime and governance in Indian country, amending codes and taking other steps necessary to exercise this authority goes to the legitimacy and capacity of tribes as governments. Tribes see this as important because it fulfills a duty to protect

Native Cmty. v. Salazar, 935 F. Supp. 2d 195 (D.D.C. 2013); see also Akiachak Native Cmty. v. U.S. Dep't of Interior, No. 13-5360, 2016 WL 3568092 (D.C. Cir. July 1, 2016).

159. See Sharon Dolovich, Legitimate Punishment in Liberal Democracy, 7 BUFF. CRIM. L. REV. 307, 352-56 (2004) (noting that, without protection of security, other life goals can mean little).

160. See DEER, supra note 14, at 31-32; see also Hon. Peter Yucupicio, Chairman, Pascua Yaqui Tribe of Arizona, Statement Before the Office of Tribal Justice (Oct. 15, 2014), in CONSIDERATIONS IN IMPLEMENTING VAWAS SPECIAL DOMESTIC VIOLENCE CRIMINAL JURISDICTION AND TLOA'S ENHANCED SENTENCING AUTHORITY: A LOOK AT THE EXPERIENCE OF THE PASCUA YAQUI TRIBE 50, 54 (2014) ("The first responsibility of any government, tribal or otherwise, is the safety and protection of its people, for there can be no security or freedom for all, if there is insecurity and fear for any of us. Pascua Yaqui tribal officials no longer have to simply stand by and watch their women be victimized with no recourse.").

161. See United States v. Mazurie, 419 U.S. 544, 556-58 (1975) (affirming the tribal convictions of non-Native defendants who illegally sold liquor, based in part on recognition of Indian sovereignty over criminal matters); Angela R. Riley, (Tribal) Sovereignty and Illiberalism, 95 CALIF. L. REV. 799,835 (2007). 
tribal members, but also because it is a central assertion of sovereignty over territory, regardless of who is within territorial boundaries. ${ }^{162}$

Tribes retain their inherent, sovereign authority that long predates the formation of the United States and the adoption of the United States Constitution. Undoubtedly, however, the federal government has curtailed that sovereignty over time. ${ }^{163}$ In many instances, the Court has gone even further than Congress in the field of federal Indian law, making its own federal Indian "common law"164 in setting limits on tribal sovereignty. ${ }^{165}$ In recent years, this has meant hostility towards Indian tribal sovereignty and a slew of cases that limit that authority pursuant to what the Court has called tribes' "diminished" status. ${ }^{166}$

Accordingly, while tribes continue to assert their sovereignty, selfgovernance, and treaty rights, it is clear that the federal government-and the Supreme Court in particular-views the sovereign authority of tribes as less than complete. The inapplicability of the U.S. Constitution to Indian tribal governments ${ }^{167}$ and the corresponding limits on federal court review

162. See 2008 Hearing, supra note 84, at 35 (statement of Kelly Gaines Stoner, Director, Native American Legal Resource Center and Clinical Programs, Oklahoma City University School of Law) ("First, a government-to-government approach should be included in the preamble of the proposed statute. As sovereign nations, tribal governments have the ultimate interest in executing sovereign responsibilities and ensuring the safety of anyone who comes within tribal boundaries. A government-to-government approach ensures the proper deference for both sovereigns and maintains focus on the thread of commonality each must address, which is the safety of victims and criminal accountability issues.").

163. See, e.g., Cherokee Nation v. Georgia, 30 U.S. 1, 17 (1831) (noting for the first time that Indian tribes were "domestic dependent nations"); $c$. Sarah Krakoff, A Narrative of Sovereignty: Illuminating the Paradox of the Domestic Dependent Nation, 83 OR. L. REV. 1109 (2004) (explaining the complex nature of sovereignty for an Indian nation). But see Major Crimes Act, 18 U.S.C. $§ 1153$ (2012) (extending federal criminal jurisdiction over various felonies even if committed by Natives on Native land); Indian General Allotment (Dawes Severalty) Act, 25 U.S.C. § 331 (2012) (repealed 2000) (authorizing the federal government to divide Native land into allotments); Lone Wolf v. Hitchcock, 187 U.S. 553 (1903) (upholding the broadest possible reading of Congress's plenary authority over Indian affairs); H.R. Con. Res. 108, 83d Cong. (1983) ("Whereas it is the policy of Congress, as rapidly as possible . . . to end [the Indians'] status as wards of the United States.").

164. See generally Frickey, supra note 80.

165. See, e.g., Montana v. United States, 450 U.S. 544 (1981); Oliphant v. Suquamish Indian Tribes, 435 U.S. 191 (1977), superseded by statute in part, Department of Defense Appropriations Act of 1991, Pub. L. No. 101-511, § 8077(b)-(c), 104 Stat. 1856, 1892-93 (1990) (codified at 25 U.S.C. § 1301(2), (4)); see also Duro v. Reina, 495 U.S. 676 (1990), overturned by 25 U.S.C. § 1301 (affirming Indian tribes' inherent sovereignty to exercise criminal jurisdiction over "all Indian").

166. See David H. Getches, Beyond Indian Law: The Rehnquist Court's Pursuit of States' Rights, ColorBlind Justice and Mainstream Values, 86 MiNN. L. REV. 267, 281 (2001) (noting that convicted criminals prevail more often before the Supreme Court than do American Indian tribes).

167. See Talton v. Mayes, 163 U.S. 376, 380 (1896). 
of tribal court cases regarding civil rights have only increased skepticism about tribal power. ${ }^{168}$

Thus, the enactment of both TLOA and VAWA raises a paradox for Indian tribes. On the one hand, both statutes bolster some aspects of tribes' inherent, sovereign authority to prosecute and punish those who commit crimes in Indian country. At the same time, that expanded sovereignty comes at a price-and potentially assimilative mandates are at the heart of the bargain. As scholars have noted in the past, while the American Bill of Rights is a "great achievement" for an American society built on integration, equality, and antidiscrimination, for Indian tribes its potential for destruction likely far outweighs its aspirational qualities. ${ }^{169}$

TLOA and VAWA both impose additional requirements onto tribes that do not otherwise bind them. After more than a century of assimilative policies that sought to destroy tribal language, culture, and religion, Indian tribes today are in a period of revitalization and are, therefore, wary of any further federal imposition onto internal tribal life, governance, and culture. ${ }^{170}$ Some scholars have suggested that extension of the entire Bill of Rights to tribal governments, particularly if accompanied by federal court review, could potentially undermine or even annihilate tribal cultures. ${ }^{171}$

Accordingly, throughout debate over both laws, tribes were questioned by the community, the press, and policymakers as to the compatibility of an American adversarial model of criminal justice with a tribal context. Reminiscent of the tribal response to ICRA, ${ }^{172}$ Indian communities viewed with skepticism the introduction of new federal laws that bring tribal courts more in line with those of

168. See Santa Clara Pueblo v. Martinez, 436 U.S. 49 (1978). For an argument that tribes should enter into treaties with one another to create an Indian-based institution to review internal tribal decisions, see Wenona T. Singel, Indian Tribes and Human Rights Accountability, 49 SAN DIEGO L. REV. 567 (2012).

169. Milner S. Ball, Stories of Origin and Constitutional Possibilities, 87 MiCH. L. REV. 2280, 2306 (1989).

170. See Carpenter \& Riley, supra note 155, at 203 (noting that, due to colonization, "tribes may overtly resist changes otherwise desirable that may be perceived as too Western"); see also Joseph P. Kalt \& Joseph William Singer, Myths and Realities of Tribal Sovereignty: The Law and Economics of Indian Self-Rule 3 (Harvard John F. Kennedy Sch. of Gov't, Working Paper No. RWP04-16, 2004), http://ssrn.com/abstract=529084 (arguing that, without self-governance, tribes will cease to exist as distinct political entities within the United States).

171. See Alex Tallchief Skibine, Respondent's Brief-Reargument of Santa Clara Pueblo v. Martinez, 14 KAN. J.L. \&PUB. POL'Y 79, 87 (2004); see also Riley, supra note 161, at 835-47.

172. See U.S. COMM'N ON CIVIL Rights, THE INDIAN CiVIL RigHTS ACT 9-10, 40 (1991) (citing Rights of Members of Indian Tribes: Hearing Before the Subcomm. on Indian Affairs of the Comm. on Interior and Insular Affairs on H.R. 14419 and Related Bills, 90th Cong. 128 (1968), and noting testimony of tribal leaders as asking why tribes are not afforded "inalienable rights ... protected as our customs and traditions require"). 
American courts. ${ }^{173}$ In these discussions, tribes interested in implementing the new statutes attempted to explain some cultural and historical connection between their way of handling crime and contemporary individual rights protections as mandated by the federal laws. As a tribal leader at Pascua Yaqui emphasized:

For hundreds of years Pascua Yaqui ancestors fought to preserve the territorial integrity of their homeland and to protect their people. The recent decision to exercise SDVCJ to protect tribal victims is a mission that is consistent with that history. . . The new program is consistent with Yaqui tradition and culture, namely protecting our people and providing fairness to the accused. ${ }^{174}$

The tribal leader went on to explain how tribal criminal jurisdiction is rooted in a Yaqui view of the world in which the tribe has inherent authority and responsibility to protect and provide for the people. ${ }^{175}$ Historically, law enforcement functioned largely through ceremonial societies and clan affiliations. ${ }^{176}$ Having someone speak on your behalf and ensuring fairness are both "deeply rooted in Yaqui indigenous tradition and practice,"177 and are based in tribal cultures that "pre-date the U.S. Constitution and the Bill of Rights and are rooted in beliefs that are arguably as old as English Common Law." ${ }^{178}$

Other tribal communities similarly expressed concern that implementation of the two statutes would force tribes more towards assimilation into the American model, and they would concomitantly "los[e] the features of their own justice traditions" if they adopted them. ${ }^{179}$ The Chief Justice of the Tulalip Tribes located this concern, in particular, in some of the TLOA requirements around defendants' due process rights, and the fear that those changes in tribal court procedure "will push Tribal courts to be more like federal courts, and this is not typically a welcomed push." 180 She explained further: "Tribes may judge the changes in TLOA coming at too high a cost to their sovereignty and independence." ${ }^{181}$ The requirement of a mixed jury

173. See Carpenter \& Riley, supra note 155, at 203.

174. NAT'LCONG. OF AM. INDIANS, supra note 152, at 3-4.

175. See Yucupicio, supra note 160, at 50-56.

176. See id. at 51 .

177. Id. at 52 .

178. $I d$.

179. Laird, supra note 31.

180. Tribal Law and Order Act One Year Later: Have We Improved Public Safety and Justice Throughout Indian Country?: Hearing Before the Comm. on Indian Affairs, 112th Cong., 56 (2011) [hereinafter Tribal Law and Order Act One Year Later] (statement of Hon. Theresa M. Pouley, Chief Judge, 181. Id. Tulalip Tribal Court). 
pool - mandating inclusion of non-Indians on tribal juries for tribes to exercise special domestic violence jurisdiction under VAWA - was also an issue of serious concern for tribes wary of allowing more control in tribal communities by outsiders. ${ }^{182}$ Some of the Pueblos, including Hopi, emphasized this objection. $^{183}$

To balance the competing tensions between sovereignty on the one hand and assimilation on the other, tribes took various approaches. At Tulalip, for example, Judge Pouley notes that one solution was to "carefully study ways to implement the provisions of TLOA while still retaining our Tribal identity and balancing extended punishment philosophies with the holistic programs and methods that have been successful over the years." ${ }^{184}$ She noted that the process has been difficult and required the cooperation of all the stakeholders in the justice system. ${ }^{185}$ Similar concerns were raised at places like Hopi as well, and it was the participation of women and the sharing of their stories at Council meetings that ultimately swayed the Hopi Tribe to move towards adoption of TLOA. ${ }^{186}$ According to the lead attorney at Umatilla, Brent Leonhard, it was not such a controversial issue there, as the tribe was already providing most of the protections in tribal court as required under the U.S. Constitution. ${ }^{187}$ He noted, "[a]t Umatilla, what's happened is that the tribe is giving the same rights to nonIndians that they give to their own tribal members."'188 In this sense, the cases at Umatilla were "unremarkable."189

Each tribe has had to think about the issue as it relates to its particular circumstances, including the potential for assimilative impositions. One safeguard for tribes is the flexibility built into the statutory standards, particularly in regards to both lawyers and judges. The debates leading up to passage of both acts reveal

182. See FOLSOM-SMITH, supra note 83, at 10 (citing concerns of the Hopi Tribe in particular). At the debates over ICRA, tribes also expressed resistance to the idea of juries determining guilt or innocence. See U.S. COMM'N ON CIVIL RIGHTS, supra note 172, at 8-9 (citing Rights of Members of Indian Tribes: Hearing Before the Subcomm. on Indian Affairs of the House Comm. on Interior and Insular Affairs, 90th Cong. 37 (1968) (statement of Domingo Montoya, Chairman of the All Indian Pueblo Council of New Mexico)) (arguing that it is not logical to use a jury system in disputes within the Pueblo).

183. See Lee Allen, Are Tribal Courts Developed Enough for VAWA? Pascua Yaqui Proves It, INDIAN COUNTRY TODAY (May 20, 2015), http://indiancountrytodaymedianetwork.com/2015/ 05/20/are-tribal-courts-developed-enough-vawa-pascua-yaqui-proves-it-160421 [https://perma.cc/DRA5-4S7B].

184. Tribal Law and Order Act One Year Later, supra note 180, at 56.

185. See id.

186. See FOLSOM-SMITH, supra note 83, at 1 .

187. Id.

188. NINC2004, VAWA Panel, YOUTUBE (Apr. 18, 2015), https://www.youtube.com/watch? $\mathrm{v}=\mathrm{voKIvF3a9Wc}$ [https://perma.cc/JHF5-G9MC].

189. See Laird, supra note 31 . 
that this malleability was intended to address both cultural (assimilation) and practical (resources) concerns.

In regards to judges' qualifications, for example, both statutes were left somewhat vague due to the proliferation of judges in tribal communities that have not been trained in ABA-accredited law schools. ${ }^{190}$ Historically, some tribal judges, for example, were selected because of their status as elders within the community, their deep cultural knowledge, or their standing in the tribe. Such knowledge has not always required formal law training from a tribal perspective, and, in fact, may be inapposite to it. Oftentimes, a tribe's perspective of what qualifies a judge may be quite distinct from an American perspective. This is particularly true where tribes have adopted traditional, indigenous-based forms of dispute resolution, such as with the model set by the Navajo Peacemaker Court, where formal Western legal training may even be viewed as a detriment. ${ }^{191}$ But even within tribes that follow the adversarial model more closely, it is not uncommon to find judges that have not been trained in an American law school. ${ }^{192}$ The same is true of tribal lawyers, some of whom are not law-trained, but are trained as "lay advocates" for purposes of practice within tribal courts. ${ }^{193}$

Despite all the possible assimilationist costs, the pilot project tribes saw the implementation of special domestic violence criminal jurisdiction as an absolute necessity for sovereignty. This had both a practical and theoretical justification. The absence of jurisdiction was destroying the tribes' ability to govern and protect people, to engage in economic development, and to prosper. Crime was high. People had begun to lose faith in the criminal justice system altogether, and this was true of both tribal and federal systems. This lack of law enforcement, as was well documented in the testimony leading up to VAWA's reauthorization, contributed to a sense of lawlessness on the reservation. Tribal members experienced the criminal justice system as futile and ineffective, and, in many cases, even

190. See 25 U.S.C. § 1302(c)(1)-(2) (2012).

191. See Robert Yazzie, Healing as Justice: The Navajo Response to Crime, in JUSTICE AS HEALING: INDigENOUS WAYs 121, 130-31 (Wanda D. McCaslin ed., 2005); Robert Yazzie, "Life Comes From It": Navajo Justice Concepts, in NAVAJO NATION PEACEMAKING: LIVING TRADITIONAL JustiCE 42, 51-52 (Marianne O. Nielsen \&James W. Zion eds., 2005).

192. See NAT'L CONG. OF AM. INDIANS, COMPARING THE IMPLEMENTING CODE OF THE FIVE PILOT TRIBES: TRIBAL PILOT PROJECT OF VAWA 20134 (2015), http://tloa.ncai.org/ documentlibrary/2015/09/Comparison\%20of\%20Five\%20Pilot\%20VAWA\%20Tribes.pdf [https://perma.cc/VM4M-AAGX] (noting that at Fort Peck, for example, the chief judge is not law trained in an American law school, but is tribally certified, has an undergraduate education, and participates in annual trainings). The same is true of state court judges in places like Montana, where there is a limited pool of available judges.

193. Of course, even where parties do have a guaranteed right to counsel, it is often lacking. See generally AMY BACH, ORDINARY INJUSTICE: HOW AMERICA HOLDS COURT (2009) (discussing systems where overworked defense attorneys have no time to meet clients or lodge a defense). 
stopped calling law enforcement for help. Tribal members also begin to detach from the criminal justice system altogether, refusing to participate as witnesses or in other ways. Offenders also have this view of tribal justice as ineffectual. As a case in point, when one defendant was arrested for domestic violence, he stated to tribal police, "[y]ou can't do anything to me anyway." 194

Although many tribes have expressed a desire to implement TLOA or VAWA, most have not yet done so. ${ }^{195}$ As tribes consider their options, a key factor in decisionmaking and in negotiating the possible downsides-including risks of further assimilation - will be whether the laws are having a positive impact on the ground. In many respects, it is difficult to draw definitive conclusions here. There is a severe paucity of data collection with respect to Indians and Indian country issues to set a baseline from which to evaluate change. ${ }^{196}$ In fact, the dearth of data in the area of Indian country criminal justice makes it exceedingly difficult for tribes, tribal leaders, and the federal government to adequately assess the gaps in Indian country criminal justice. Though there has been increased focus on data collection in Indian country in the last decade, sources are still scant. Thus, the experience of the pilot project tribes provides even more critical guidance for Indian nations.

Research reveals that prior to 2013, the pilot project tribes felt impotent in protecting tribal members, and the problem of domestic violence raised particular issues at places like Pascua Yaqui, where domestic violence is a large part of the criminal docket. ${ }^{197}$ On February 26, 2014, Pascua Yaqui arrested and began prosecution of the first non-Indian defendant since Oliphant. During the pilot project period, twenty-five percent of the domestic violence cases at

194. NAT'LCONG. OF AM. INDIANS, supra note 152 , at 4.

195. By the end of the relevant period, only three of the five pilot project tribes had initiated prosecutions under VAWA; only approximately nine tribes in the United States had become TLOA compliant. See FOLSOM-SMITH, supra note 83, at 8 (noting that, as of January 2015, only three months before the end of the relevant period studied, nine tribes-Hopi Tribe, Tulalip Tribes, Cherokee Nation of Oklahoma, Eastern Band of Cherokee Nation, Confederated Tribes of the Umatilla Reservation, Fort Peck (Assiniboine \& Sioux Tribes), Salt River Pima-Maricopa Indian Community, Muscogee (Creek) Nation of Oklahoma, and Pascua Yaqui-had implemented TLOA and sentenced defendants to enhanced sentencing). As of the date of this writing, only eight tribes had implemented VAWA, though there are approximately forty-five tribes who have volunteered to collaborate on Special Domestic Violence Criminal Jurisdiction under VAWA through the Inter-Tribal Working Group. NAT'L CONG. OF AM. INDIANS, supra note 30, at 21; see, e.g., U.S. DEPT. OF JUSTICE, TRIBAL LAW AND ORDER ACT REPORT ON ENHANCED TRIBAL-COURT SENTENCING AUTHORITY 5, https://www.justice.gov/tribal/ file/796981/download [https://perma.cc/4XPZ-BU5B].

196. See Riley, supra note 64, at 1733 (discussing the data gaps with respect to crime in Indian country, and citing to the few sources that are beginning to fill these gaps); see also DEER, supra note 14, at 2 (noting that "[i]t is notoriously difficult to gather data about Native people—on any topic").

197. Pascua Yaqui Annual Report (on file with author). 
Pascua involved non-Indian defendants. ${ }^{198}$ As the statistics bear out, these defendants had essentially terrorized the reservation for years. In the four years prior to and during the pilot project period, the fifteen non-Indian defendants prosecuted at Pascua Yaqui under SDVCJ had more than eighty documented prior tribal police contacts. All of these incidences occurred on the reservation. The perpetrators had deep ties to the tribal community. Most of them had long criminal records. Two had outstanding arrest warrants, one for armed robbery in the state of Oklahoma. ${ }^{199}$ Two of the offenders were convicted felons with Arizona criminal records. None of the defendants were subject to tribal criminal jurisdiction until the pilot project was initiated. ${ }^{200}$

Each of the VAWA pilot project tribes has unique demographic features that made the expanded jurisdiction under VAWA important to sovereignty. First and foremost, each tribe identified domestic violence against the Native population as an important problem that the tribe needed to address. But, beyond this core common feature, the tribes represent a wide range of tribal communities in almost every other respect. In terms of land base, Pascua Yaqui is situated on only 2200 acres of land, ${ }^{201}$ while Tulalip's Reservation is ten times that size, ${ }^{202}$ and Umatilla is almost eight times the size of Tulalip. ${ }^{203}$ To put this in perspective, Pascua Yaqui has a reservation population of 4000 to 5000 residents at any given time living on fewer than four square miles, while Umatilla has a population of 3200 on a reservation that is 270 square miles. ${ }^{204}$ Both Pascua Yaqui and Tulalip ${ }^{205}$ have relatively small non-Indian populationsbetween 10 and 15 percent respectively-while Umatilla has a non-Indian population of more than 46 percent. ${ }^{206}$ Pascua Yaqui is relatively urban (near Tucson) and is also near the border with Mexico. ${ }^{207}$ Tulalip is in the middle, located in western Washington, around 30 miles from Seattle. ${ }^{208}$ Umatilla is five miles from Pendleton, Oregon, a town of $16,000 .{ }^{209}$

\footnotetext{
198. See NAT’L CONG. OF AM. INDIANS, supra note 152, at 4.

199. See id.

200. NAT'L CONG. OF AM. INDIANS, supra note 30 , at 11 . Similarly, the CTUIR assert that the domestic violence cases prosecuted by the tribe against non-Indians during the pilot project period doubled the amount ever prosecuted by the U.S. Attorney's office.

201. NAT'LCONG. OF AM. INDIANS, supra note 30, at 6.

202. Id. at 9 .

203. Id. at 11 .

204. Id.

205. Id. at 9 .

206. Id. at 11 .

207. Id. at 6 .

208. Id. at 9 .

209. Id. at 11 .
} 
Thus, there is no standard profile of a tribe that may seek implementation of either statute. ${ }^{210}$ However, even given the very small sample size available in this analysis, some preliminary evidence begins to paint at least a partial picture as to the impact that the statutes are having on the ground. As the Special Domestic Violence Criminal Jurisdiction Pilot Project Report put together by the National Congress of American Indians notes, some key points can be extrapolated from the tribes' experiences implementing VAWA thus far. First, non-Indian domestic violence is a significant problem in Indian communities, comprising up to 25 percent of all domestic violence cases on the reservation. ${ }^{211}$ Moreover, most of the non-Indian defendants have "significant ties" to the tribal communities where they are prosecuted. ${ }^{212}$ Many lived on the reservation at the time of their arrests, were married to Indians living on the reservation, or had children with tribal members. ${ }^{213}$ The report concluded that finally having jurisdiction over crimes by these perpetrators allowed "the participating tribes to prosecute many long-time repeat offenders who had threatened the tribal community." 214 Thus, the laws have made a profound difference for these tribes. They are able to prosecute and incapacitate defendants who have committed ongoing acts of domestic violence for years.

Similarly, the pilot project tribes point to the sharp increase in reporting of domestic violence as another sign that the laws are having a positive impact. Of course, one possibility for an increase in reporting could be an increase in domestic violence cases generally, and the reported numbers may merely reflect that trend. But tribal officials have an alternate explanation. Tulalip states, for example, that since VAWA was reauthorized, reporting of domestic violence has gone up steadily. ${ }^{215}$ CTUIR similarly acknowledges increases in reporting during the same period. Those working in tribal criminal justice posit that this is because victims believe they are safer than before, and that their abusers will not automatically walk free due to jurisdictional loopholes. ${ }^{216}$

210. In fact, given that resources are the largest barrier to implementing both TLOA and VAWA, the greatest commonality between the three tribes may be that they had the resources for implementation.

211. NAT'LCONG. OF AM. INDIANS, supra note 30, at 25.

212. Id.

213. Id. at $25-26$.

214. Id. at 25 .

215. See Tribal Justice: Prosecuting Non-Natives for Sexual Assault on Reservations, PBS NEWSHOUR, (Sept. 5, 2015, 1:08 PM), http://www.pbs.org/newshour/bb/tribal-justice-prosecuting-nonnatives-sexual-assault-indian-reservations/ [https://perma.cc/AKK4-DGWY] (quoting Theresa Pouley, chief judge on the Tulalip Tribal Court, saying that reporting has gone up at Tulalip "for the last three years steadily as victims know that perpetrators will be held accountable").

216. See Leonhard, supra note 86 . 
Despite the very real fears of increased acculturation, since implementation, there has been relatively little indication of tribal members' concerns over assimilation. Of course, it may be that implementation was less jarring for the tribes that have already adopted the laws than others. Tribes most resistant to a Western model - and that would, therefore, be more likely to report a negative reaction to encroaching forces-are among the least likely to have sought implementation. Those tribes that implemented VAWA, for example, had to apply for approval to be included in the pilot project, and they did so in part because they already had in place many of the procedural mechanisms required under the statute. ${ }^{217}$ All of the pilot project tribes that initiated prosecutions under VAWA during the pilot project window, for example, already employed law-trained judges. Similarly, among these tribes the right to counsel was readily available - in some cases, for anyone who requested a lawyer, regardless of indigent status - and this had been the practice for some time. And all three tribes now use the same jury pool for all cases, regardless of the crime or race/identity of the parties. ${ }^{218}$ In other words, the pilot project tribes under VAWA and the early adopters of TLOA were already well-positioned to implement the new laws. Whatever concerns they had regarding assimilation may have already been dealt with in earlier iterations of criminal justice decisions and discussions.

Given the enormous spectrum of legal systems and cultural practices found across the more than 560 Indian nations in the United States, there is no universal answer to the question of how to balance potentially assimilative federal law with tribal culture and tradition. And, while tribes may learn from the experiences of other Indian nations, they must be mindful of the consequences of homogenizing tribal governments. If tribes are too quick to embrace these expansions without considering how they might impact tribal law, culture, and governance, this expansion in authority, in hindsight, might be seen as another instrument of assimilation to erode traditional tribal justice systems. ${ }^{219}$

At the same time, a central function of government is to keep citizens safe and to provide conditions sufficient for peace and prosperity. Where tribes are able to accommodate these expansions, side by side with policies and procedures

217. See Francesca Hillery, Tulalip Tribes One of Three Tribes Nationwide to IMPLEMENT SPECIAL DOMESTIC VIOLENCE CRIMINAL JURISDICTION UNDER VAWA 2013, at 1-2 (2014), http://www.tulaliptribes-nsn.gov/LinkClick.aspx?fileticket=oHGIB p5ufqo\%3D\&tabid=36 [https://perma.ce/6H65-ASGS] (regarding the Tulalip Tribes' implementation of the new law).

218. NAT'LCONG. OF AM. INDIANS, supra note 30, at 16.

219. See Riley, supra note 161, at 835-48 (detailing some of the unique features of tribal governance that would be destroyed with increased federal intervention). 
that bolster tribal custom and tradition, it may be in the best interest of tribal people — and tribal sovereignty — to do so.

\section{B. Individual Rights in Tribal Criminal Jurisdiction}

The tension between individual and collective rights as related to tribal communities has been evident virtually since contact between Natives and Europeans. Though there was a vast range in tribal cultures during the colonial period, a common thread among most indigenous communities, then and today, is a tightly cohesive sense of collective rights, responsibilities, and duties. For some Indians, obligations to the tribe and ceremonial life may come before the particular rights of individuals. ${ }^{220}$ As one Indian scholar has written, "[m]ost tribal Indians are raised to think independently and act for others." 21 Anathema to conceptions of Western liberalism, which put the individual at the center of rights frameworks, indigenous societies are oftentimes criticized for prioritizing tribal interests in this way. ${ }^{222}$ Scholars have long debated the question of the extent to which Indian tribes do-or ought to-appreciate and preference individual rights over collective rights. This tension has framed many of the conflicts in Indian law and policy for centuries. ${ }^{223}$

It is against this backdrop that debates around tribal criminal jurisdictionboth in terms of felony sentencing and jurisdiction over non-Indians-took place when the statutes were considered. And, not surprisingly, conversations immediately turned to the question of whether tribes would and could respect

220. See Valencia-Weber, Swentzell \& Petoskey, supra note 73, at 49 (noting that, as an indigenous woman, Eva Petoskey would "pay the price" of individual rights for her tribe's sovereignty and autonomy).

221. Robert A. Williams, Jr., Gendered Checks and Balances: Understanding the Legacy of White Patriarchy in an American Indian Cultural Context, 24 GA. L. REV. 1019, 1024(1990).

222. See, e.g., Santa Clara Pueblo v. Martinez, 436 U.S. 49 (1978).

223. There is a rich body of literature addressing this tension between indigenous peoples and liberal democracies. See, e.g., WILL KYMLICKA, LiBERALISM, COMMUNITY AND CULTURE 196-98 (1989) (indicating that Indian tribes ought to adopt liberal practices); Kristen A. Carpenter, Individual Religious Freedoms in Tribal Constitutional Law, in THE INDIAN CIVIL RIGHTS ACT AT FORTY 159 (Kristen A. Carpenter, Matthew L.M. Fletcher \& Angela R. Riley eds., 2012); Carole E. Goldberg, Individual Rights and Tribal Revitalization, 35 ARIZ. ST. L.J. 889, 891 (2003) (contending that there are ways in which individual rights may be consistent with, and even support, tribal cultures and traditions); Riley, supra note 161, at 802-03 (arguing against federal imposition of individual rights in tribal communities, but urging tribes to contemplate such concerns in the context of sovereignty and survival); Madhavi Sunder, Cultural Dissent, 54 STAN. L. REV. 495, 559-60 (2001) (arguing for federal intervention where collective rights stifle individual rights in tribal communities); Rebecca Tsosie, American Indians and the Politics of Recognition: Soifer on Law, Pluralism, and Group Identity, 22 L. \& SOC. INQURRY 359, 374 (1997) (contending that an individual rights framework cannot accommodate the unique nature of indigenous peoples' balance of collective and individual rights within tribal communities). 
and adequately protect the individual rights of criminal defendants. ${ }^{224}$ As Senator Tom Cole from Oklahoma stated, some of his colleagues seemed to "fear Indians are going to take out 500 years of mistreatment on us through this. It's that kind of fear, veiled in constitutional theories[.]"225 The question about constitutional protections and individual rights has many components. Both statutes impose in various ways new standards onto tribes and encourage greater federal court review than existed previously. ${ }^{226}$ But two features in particular garnered the greatest debate: the right to counsel for indigent defendants and the makeup of tribal juries.

The guaranteed right to counsel for indigent defendants was debated vociferously leading up to the reauthorization of VAWA in particular because it would mark the first prosecution of non-Indians by tribal courts in almost forty years. ${ }^{227}$ As noted, the ICRA does not extend a mandatory right to counsel for indigent defendants to tribes, and, at the time of VAWA's reauthorization, some tribes continued to prosecute Indians without the aid of a lawyer. ${ }^{228}$ But criticisms of the current tribal framework can be best understood within its unique historical context. The system of prosecution, trial, and incarceration in Indian country today was established by federal governmental policies more than one hundred years ago, and the right to counsel is a central feature in the long and complex story of federal-tribal relations. ${ }^{229}$

When the United States forced the adversarial system of trial and punishment onto tribes, it did so without concern for protecting the rights of Indian

224. See DEER, supra note 14 , at 103 . The question whether it would be constitutionally permissible for Congress to subject American citizens to the authority of a sovereign not bound by the Constitution has been raised both in previous case law, as well as in the conversations around VAWA's passage. See, e.g., United States v. Lara, 541 U.S. 193, 211 (2004) (Kennedy, J., concurring); Duro v. Reina, 495 U.S. 676, 679 (1990) (holding that Indian tribes may not assert criminal jurisdiction over a non-Indian); Tribal Justice: Prosecuting Non-Natives for Sexual Assault on Reservations, supra note 215 (quoting former Senator Tom Coburn on his opposition to the VAWA reauthorization).

225. Weisman, supra note 130.

226. See, e.g., 25 U.S.C. § 1304(e) (2012 \& Supp. 2013) (authorizing petitions to stay detention and allowing a stay of proceedings in some instances).

227. See, e.g., Letter from Nat'l Ass'n of Criminal Def. Lawyers \& Nat'l Ass'n of Fed. Defs., to U.S. Senators Reid, McConnell, Leahy \& Grassley, supra note 142, at 3-4 (noting that ICRA, as passed in 1968, did not guarantee criminal defendants in tribal court the right to counsel). The reason was "because neither funding to pay appointed lawyers nor a bar of private attorneys practicing in tribal courts was available." Id. at 3. This was before the U.S. Supreme Court ruled in Argersinger v. Hamlin, 407 U.S. 25, 37 (1972), that an indigent defendant facing any period of incarceration is entitled to appointed counsel.

228. See 25 U.S.C. $§ 1302$ (2012); see also United States v. Bryant, 769 F.3d 671, 681 (9th Cir. 2014) (discussing whether uncounseled tribal court convictions could be used as a predicate offense under 18 U.S.C. $§ 117(\mathrm{a}))$.

229. See HAGAN, supra note 69, at 104-25. 
defendants in this foreign system. ${ }^{230}$ Beginning largely in the late nineteenth century, the federal government dismantled tribal justice systems and created Courts of Indian Offenses (known as CIO courts or CFR courts) in Indian country. ${ }^{231}$ As Barbara Creel has written, it established an Indian police force and put into place a system of tribal "criminal justice" that has "never been "tribal." 232 The Courts of Indian Offenses were established throughout almost all of Indian country. ${ }^{233}$ The CFR courts enforced federal Law and Order Codes, and a local Bureau of Indian Affairs officer conducted proceedings. Most of the courts employed judges without legal training, allowed tribal prosecutors to serve dual roles as prosecutor and chief of police, and prohibited the presence of lawyers. ${ }^{234}$

Thus, as discussed in Part I, when Congress heard testimony about civil rights abuses in tribal courts in the 1960s, it was well established that the federal model imposed onto tribal governments had not required, allowed for, or funded paid counsel for indigent defendants. When ICRA was enacted in 1968, Congress maintained this status quo, and did not extend to tribes the requirement of paid counsel for indigent defendants. ${ }^{235}$ Unlike testimony surrounding the decision not to bind tribal governments by an establishment clause, for example - which reflected deep concerns about infringements on tribal religion and tradition, largely by Pueblo traditionalists- the legislative record shows that the decision regarding the right to counsel was driven by both cultural and fiscal considerations. ${ }^{236}$ With so few American Indian attorneys in the United States at the time, requiring counsel would necessarily allow non-Indians a more active role in American Indian tribal courts. Moreover, testimony by the Departments of Interior and Justice at the time reveals that extending the requirement of a right to counsel for indigent defendants to tribes was also undesirable because it would require the federal government to cover the cost, as

230. See, e.g., Creel, supra note 68, at 320-21.

231. See id. at 338-42.

232. Seeid. at 338 .

233. See id. at 340 (citing 25 C.F.R. § 11.9 (1958), repealed by Professional Attorneys, 26 Fed. Reg. 4360-61 (May 19, 1961); see also id. at 341 ("[T]he Commissioner and local Indian agents established Courts of Indian Offenses in every Indian agency that they themselves saw fit, with the exception of the Five Civilized Tribes, the Indians of New York, the Osage, the Pueblos, and the Eastern Cherokees. By the 1900s, Courts of Indian Offenses operated in two-thirds of the Indian agencies, and they persist to operate as the law and order court on more than twenty reservations or Indian trust lands to this day.").

234. See Fletcher, supra note 18, at 19.

235. See 25 U.S.C. $\$ 1302$ (2012); supra note 76.

236. See 1961 Hearing, supra note 76, at 13 (statement of Hon. John A. Carver, Jr.); supra note 74. 
tribes could not. ${ }^{237}$ The trade-off was reflected in the limited authority of tribes to sentence tribal defendants only to six months in jail or a $\$ 500$ fine, or both. "Thus, the anemic view of a right to counsel partially reflected the norm in state court for misdemeanor charges in 1968." 238

Accordingly, when Congress amended the ICRA in 1986 to expand tribes' sentencing authority under the ICRA — from six months to one year per count and a $\$ 5000$ monetary fine ${ }^{239}$ - it seemingly did so without reviewing or contemplating the impact the expansion would have on tribal defendants. ${ }^{240}$ Given that the original sentencing limitations were put in place at a time when Congress likely did not consider the possibility of felony prosecutions by tribal courts, the expansion in sentencing merited, but did not receive, renewed review of ICRA's provisions regarding the right to counsel for indigent defendants. ${ }^{241}$ Despite the new extended sentencing authority, no additional resources were allocated to tribes to provide defense counsel, nor was there discussion of the potential constitutional issues uncounseled convictions might raise in the future. ${ }^{242}$

In recent years, tribes, academics, and policymakers have become more vocal about the consequences of securing tribal court convictions without the aid of a lawyer. Defense attorneys and tribal advocates have increasingly called for modifications to the laws to ensure protections for all defendants in tribal court. ${ }^{243}$ These critiques are articulated both externally and internally. During field hearings, the ILOC heard extensive testimony from multiple players within the system, including prosecutors, judges, and public defenders. The Commission concluded that, "without the right to counsel, the right to due process itself is compromised. In sum, ICRA is out of step with Tribal court practice, diverges from the now broadly accepted norm for assistance of counsel in adversarial, punitive proceedings, and fails to create a coherent body of

237. The Supreme Court has ruled that it is unconstitutional to imprison a defendant without legal representation in federal court since 1938, Johnson v. Zerbst, 304 U.S. 458, 469 (1938), and in state courts since 1963, Gideon v. Wainwright, 372 U.S. 335, 344-45 (1963). State constitutional law and the rights of defendants in criminal proceedings began to grow in the 1950s and 1960s. See Stuntz, supra note 103, at 2003.

238. Creel, supra note 68, at 347.

239. See Indian Civil Rights Act of 1968, Pub. L. No. 90-284, §§ 201-203, 82 Stat. 73, 77-78 (1968) (codified as amended at 25 U.S.C. $§ \S 1301-1303$ (2006)).

240. See Creel, supra note 68, at 350-51.

241. See INDIAN LAW \& ORDER COMM'N, supra note 9, at 19 ('When ICRA was enacted, Congress likely did not contemplate felony prosecutions by Tribal courts, so this right to counsel, normally afforded to indigent defendants charged with a felony, was not included in ICRA.").

242. See Creel, supra note 68, at 348; Fletcher, supra note 18, at 19. See also United States v. Bryant, 136 S. Ct. 1954 (2016) (upholding the use of uncounseled tribal court convictions as predicate offenses for a subsequent federal prosecution).

243. See Creel, supra note 68, at 355. 
law."244 The Commission found that modifying the ICRA would not only provide more protection for criminal defendants, but would make it more consistent with existing operating procedures in tribal courts. ${ }^{245}$

To the extent empirical evidence is available, it reflects a trend in Indian country towards providing paid counsel. Even before debate began over these recent laws, when tribes have had the financial resources to provide lawyers for indigent defendants in adversarial style proceedings, they largely have done so. ${ }^{246}$ In cases where such counsel is not affordable, tribes often have provided lay advocates - those who are authorized to provide defense services to defendants, but who may not otherwise be legally trained - to indigent defendants in tribal court proceedings. ${ }^{247}$ Still other tribes have sought additional creative avenues, such as utilizing law school clinics or other resources, to fill in the gaps so that counsel may be afforded to all who appear as criminal defendants in Indian country. ${ }^{248}$

While being cautious not to draw sweeping conclusions based on a very small set of cases, the preliminary results from the relevant TLOA and VAWA cases at least lend the inference that tribes can and do respect the constitutional rights of defendants. In regards to the right to counsel, for example, all three of the VAWA pilot project tribes provide lawyers to all who want one, regardless of the crime. ${ }^{249}$ And not one non-Indian defendant prosecuted under VAWA filed a writ of habeas corpus to claim his or her constitutional rights had been violated. ${ }^{250}$ Though the remedy is available-including providing for a stay of the

244. INDIAN LAW \&ORDER COMM'N, supra note 9, at 19.

245. See id.

246. See id. (noting that providing counsel is "accepted procedure in a growing number of Tribal courts"); see also Washburn, Tribal Courts and Federal Sentencing, supra note 25, at 430 (noting that a "substantial number" of tribes provide counsel free of charge to indigent defendants).

247. See Fortin, supra note 87, at 102 (speaking of the role of lay advocates in tribal court systems); Washburn, Tribal Courts and Federal Sentencing, supra note 25, at 430-32.

248. One such program exists at the University of Washington Law School. See Tribal Court Public Defense Clinic, U. WASH SCH. L., http://www.law.washington.edu/clinics/tribal/ [https://perma. $\mathrm{cc} / \mathrm{F} 2 \mathrm{Q} 7-\mathrm{PQMB}]$.

249. NAT'L CONG. OF AM. INDIANS, supra note 30.

250. Tribal Justice: Prosecuting Non-Natives for Sexual Assault on Reservations, supra note 215 (reporting the statement of Sam Hirsch as commenting that not one non-Indian defendant has filed a writ of habeas corpus when detained under VAWA). Given the small number of cases, it is too soon to draw broad conclusions from the early prosecutions. In fact, it might be the case that more habeas petitions is the sign of a healthy criminal justice system, not a corrupt one. But see Carrie E. Garrow, Habeas Corpus Petitions in Federal and Tribal Courts: A Search for Individualized Justice, 24 WM. \&MARY BILL RTS. J. 137, 147-48 (2015) (noting that since ICRA's passage in 1968, there have been only thirty habeas petitions filed in federal court, and almost half of those were dismissed for failure to exhaust tribal court remedies, citing this as evidence that tribal courts respect civil rights). 
proceedings in tribal court and requiring that defendants be expressly notified of the right to counsel - the defendants simply have not wanted to proceed in federal court. ${ }^{251}$ It is possible, of course, that tribal court defendants have taken this position entirely out of self-interest, merely fearing a harsher result in another forum.

However, tribal attorneys have posited other rationales for the absence of writs. In fact, as CTUIR reports, the Tribe's Office of Legal Counsel encouraged the first defendant under VAWA to file a habeas petition to test the statute. The tribe realizes there will be an eventual test case, and they are confident in their proceedings and practices; thus, they have actually encouraged an appeal. But that defendant and all subsequent defendants chose not to do so. As an attorney for the tribe stated, "[i]t appears he preferred having the case handled by the tribal court rather than literally making a federal case of it." 252 In addition, not one defendant during this period filed a challenge to test the constitutionality of VAWA. ${ }^{253}$ During the period relevant to this study there is only one reported case of a constitutional challenge to a conviction under the TLOA, and it dealt with the question of retroactive application of TLOA's protections. ${ }^{254}$

In addition to the fact that providing counsel in tribal court is merely a codification of the trend in tribal court practice in general, ${ }^{255}$ tribes know that providing effective counsel in tribal court is good for tribal sovereignty. When it comes to Indian defendants, for example, tribal governments have powerful incentives to ensure fairness. Whether Indian defendants are tribal members or not, they are indigenous: They likely have ties within the community, often through family, friends, or extended religious or clan relations. ${ }^{256}$ These all provide meaningful incentives for tribal governments to be fair, just, and legitimate, seeking to act as "good governments" to advance victims' rights while ensuring fair criminal processes for defendants. ${ }^{257}$

251. See Leonhard, supra note 86 , at 21.

252. Id.

253. See Tribal Justice: Prosecuting Non-Natives for Sexual Assault on Reservations, supra note 215.

254. See Johnson v. Tracy, No. CV-11-01979-PHX-DGC, 2012 WL 4478801, at *2-3 (D. Ariz. Sept. 28, 2012) (granting the writ of habeas corpus under TLOA and remanding when defendant's arrest and prosecution took place prior to enactment of the TLOA, but before the defendant's trial).

255. See INDIAN LAW \&ORDER COMM'N, supra note 9, at 19.

256. See United States v. Lara, 541 U.S. 193, 222-23 (2004) (reviewing the constitutionality of the Duro fix which authorizes tribal criminal jurisdiction over nonmember Indians).

257. See Riley, supra note 109, at 1049 (arguing that "good Native governance mandates that tribal nations ... allow for the evolution of tribal government in ways that restore and maintain fairness, balance, and inclusion in tribal communities"). 
As to non-Indians tried under VAWA, tribal governments have similar motivations and concerns. ${ }^{258}$ By definition-as discussed in Part I-for a defendant to be prosecuted under VAWA, he or she must have deep ties to the victim and the community. This means many of the same considerations that must be weighed in prosecuting Indians-who are parents to Indian children, employees of the tribe, etc.-are present in these cases as well. Much of the testimony and information leading up to and since the implementation of the statutes demonstrate pride on the part of tribal court staff — judges, clerks, lawyers, and others—regarding the quality of justice and fairness tribal courts are able to provide, often with a fraction of the resources available to state and federal courts. ${ }^{259}$ There is no indication that tribes seek to exploit or abuse non-Indians in an exercise of power. ${ }^{260}$ To do so would be to signal that tribes are petty, corrupt, and incapable of functioning as legitimate governments. ${ }^{261}$ This is entirely against larger tribal objectives of greater selfdetermination, jurisdiction, and respect. ${ }^{262}$

Many of the same concerns regarding the right to counsel translated to whether non-Indian defendants could get a fair trial in tribal court, which motivated the concession that guaranteed defendants a cross-section of the community in a jury trial. ${ }^{263}$ Of all the cases brought under the special domestic violence criminal jurisdiction provision of VAWA during the pilot project periodaround two dozen - only one went to trial. ${ }^{264}$ That case, prosecuted by Pascua Yaqui, involved a same-sex domestic violence charge committed by one man against the other, who were, according to the prosecution, in an intimate samesex relationship. The jury was comprised entirely of Pascua Yaqui Indians, with

258. See CORNELl, CuRTIS \& JORGENSEN, supra note 109, at 6 (explaining that "[e]ffective governments ... tend to have the respect of outsiders").

259. See 2008 Hearing, supra note 84, at 52 (quoting W. Patrick Ragsdale, Director, Office of Justice Services, U.S. Department of the Interior, as indicating that a "gap analysis" shows that most tribal police forces are operating with one-third to one-half as many resources as one would find in other rural law enforcement agencies, which "is not really a real high standard").

260. See Laird, supra note 31 (quoting Sharon Jones-Hayden that the first Tulalip trial of a non-Indian under VAWA § 904 was as "routine" and "unremarkable" as the trials of Indians); see also INDIAN LAW \& ORDER COMM’N, supra note 9, at 22 (quoting William Johnson, the Umatilla Chief Judge, as stating, "We don't want to mistreat anybody. We want to give due process, a fair trial").

261. See DEER, supra note 14, at 149 (discussing the increased scrutiny tribal courts will face after implementation of the new statutory regimes).

262. See CORNELl, CURTIS \& JORGENSEN, supra note 109, at 4-6 (explaining that some form of governance is present in and necessary for all human societies to function effectively, and noting that " $t]$ he necessity for capable governance appears to be as true for indigenous nations as it is for others").

263. See Weisman, supra note 130; see also Washburn, American Indians, supra note 25, at 745-62 (noting the irony that American Indians rarely receive a jury of their peers in federal criminal trials).

264. NAT'LCONG. OF AM. INDIANS, supra note 30 , at 7. 
the exception of the foreman, who was African-American. The result: The one and only non-Indian defendant in the past forty years to be prosecuted by an Indian tribe and tried by a reservation-based jury resulted in an acquittal. ${ }^{265}$ The jury based its decision on its view that the prosecution had not sufficiently proven the existence of an intimate relationship between the two men, a requirement under VAWA.

Needless to say, broad, overarching conclusions cannot be drawn from one single case. Not until there are more trials, with more defendants, and more mixed juries, will there be a clearer picture as to the justice tribes mete out. At the same time, in Indian country, the case has come to stand for the proposition that non-Indians unquestionably can get a fair trial in tribal court. Despite all hesitations about whether tribal courts can and will be fair when trying non-Indians, the case is a point to the contrary. Currently, both for better political participation by all reservation residents and for the sake of efficiency, all three VAWA pilot project tribes use a mixed jury pool for all their tribal court cases. ${ }^{266}$

Undoubtedly, the imposition of some individual rights into tribal systems may challenge or even threaten tribal distinctiveness. ${ }^{267}$ And tribes are right to be wary of encroaching laws that seek to turn tribes only into mini-models of state or federal tribunals. At the same time, the absence of some procedural protections, such as the right to counsel, may arguably be inadvertent holdovers from the incomplete imposition of a federal system that imparted adversarial procedures without corresponding safeguards, and that may now be ameliorated by the rise in the number of Native lawyers. Thus, some tribal practices today may not be reflective of indigenous culture at all, but, rather, a consequence of colonial rule. ${ }^{268}$ Where tribes have partially adopted a Western system of trial and incarceration, it may be the intuitive and appropriate next step to ensure defendants - most of whom will be Indians, at least in the short term-receive the same protections as others in an adversarial criminal system.

265. See Pascua Yaqui Experience, referring to the case of Pascua Yaqui Tribe v. Montae Lamont Garris, CR-14-432 (Nov. 14, 2014). This experience is reflective of tribal court litigation in the civil context as well, where defendants may be a mix of Indian and non-Indian. See Bethany R. Berger, Justice and the Outsider: Jurisdiction Over Nonmembers in Tribal Legal Systems, 37 ARIZ. ST. L.J. 1047, 1074-79 (2005) (demonstrating that Navajo nation courts are balanced in their treatment of Navajo and outsiders).

266. NAT'LCONG. OF AM. INDIANS, supra note 30, at 16.

267. See Robert Odawi Porter, Strengthening Tribal Sovereignty Through Peacemaking: How the AngloAmerican Legal Tradition Destroys Indigenous Societies, 28 COLUM. HUM. RTS. L. REV. 235, 272 73 (1997) (noting that an emphasis on individual rights infringes on tribal cultural values).

268. See S. James Anaya, Indian Givers: What Indigenous Peoples Have Contributed to International Human Rights Law, 22 WASH. U. J.L. \& POL'Y 107, 108 (2006) (describing the colonial vestiges of Western law and its impact on indigenous peoples). 


\section{Crime and (Tribal) Punishment}

The story of American criminal justice, particularly as it relates to the incarceration of people of color, has been one of excessive policing, rabid criminalization, and long sentences. But, as pointed out in this Article, the story of criminal justice in Indian country - as with many aspects of federal Indian law - is the opposite. Indian country suffers from gross neglect, characterized by a long history of federal law that attempted to make Indians literally and conceptually invisible, through policies of failed assimilation and geographic confinement. Today, federal limitations are as much legal as geographical, as tribes have found themselves trapped in a "maze"269 of criminal justice where the federal government has failed to provide the concomitant protections required to satisfy its trust responsibility to Indian tribes.

Thus, in a country where the criminal justice system has been characterized by overpolicing and harsh penalties, tribes have been left to fend for themselves, toiling on reservations with scant resources and strict sentencing limitations. In contrast to the national conversation, focused on how and to what extent criminal penalties should be softened, tribal advocates pushed for TLOA with the opposite motivation: enhanced sentencing authority. In advocating for enhanced sentences, policymakers focused on the disparity in sentencing authority available to tribes vis-à-vis states in particular. ${ }^{270}$ Tribal leaders pointed out that, although expanding tribal authority from one year to the three years authorized under TLOA does not put tribes on equal footing with states in most cases, it does take a meaningful step towards leveling the playing field, at least in regards to sentencing.

Tribal advocacy around this issue focused on a couple of key factors. First, when felonies occurred on the reservation, the absence of federal prosecution left many crimes unaddressed, feeding a sense of lawlessness and hopelessness. This shifted prosecutorial authority to tribes, who were only able to impose sentences of one year per count, even for major crimes like rape and murder. This combination of factors - very low probability of prosecution and very light sentences if convicted-led to deterioration in both belief and participation in the justice system and, concomitantly, safety and security on the reservation.

269. See Clinton, Jurisdictional Maze, supra note 8.

270. See M. Brent Leonhard \& Cisco Minthorn, A Comparison of State Low Level Felony Sentencing Authority, in Tribal Courts and the Administration of Justice in Indian Country: Hearing Before the $S$. Comm. on Indian Affairs, 110th Cong. 102-06 (2008) (examining how states have defined their lowest level felony to determine the appropriate maximum sentencing for tribes). 
Thus, in pursuing prosecutions under TLOA and VAWA, respectively, tribes have been able to shrink the disparity between tribal and other governments in matters of criminal justice. Virtually all of the prosecuting tribes employ some alternatives to incarceration, including diversion courts, batterer treatment programs, or other culturally relevant treatment programs. Nevertheless, these options seem to have been exercised less than they might otherwise be, partially because many federal grants and funding streams are distinctly geared towards an American carceral model.

Though TLOA data is particularly opaque, there were approximately thirty to forty TLOA prosecutions during the relevant time frame. ${ }^{271}$ Precise sentences in each case are not known, though reporting by the Bureau of Prisons demonstrates that felony sentencing was applied in at least a dozen cases. Undoubtedly, where TLOA felony sentencing is utilized, it can make a significant difference in the sentence of the defendant and, quite possibly, in the lives of victims or potential victims, particularly if the defendant is a repeat offender. ${ }^{272}$ Of the more than two dozen arrests under VAWA jurisdiction during the relevant period, most were handled similarly to cases in the state and federal systems. In some instances, after arrest, no charges were filed. ${ }^{273}$ In others, charges were filed but subsequently dismissed due to lack of evidence or because of a failure to meet the requirements for tribal jurisdiction. ${ }^{274}$ Others were referred to the federal government for prosecution, due either to the severity or nature of the crime. ${ }^{275}$ Of those that made their way through the criminal justice process, the vast majority resulted in guilty pleas. ${ }^{276}$ Curiously, those tribes that were also TLOA compliant during the project period did not, in even one case, seek enhanced sentencing for a VAWA prosecution.

During the course of the early VAWA prosecutions, tribes and tribal advocacy groups encouraged defendants to file writs of habeas corpus to appeal their

271. See FOLSOM-SMITH, supra note 83, at 10.

272. See Tribal Law and Order Act of 2010, Pub. L. No. 111-211, § 234(a)(2), 124 Stat. 2261, 2280 (2010) (amending ICRA to extend maximum sentences from one year per count to three years per count, up to a total of nine years).

273. NAT'L CONG. OF AM. INDIANS, supra note 30, at 5.

274. Some tribes have reported dismissing cases based on so-called Castleman issues, based on Justice Scalia's concurrence in the case United States v. Castleman. 134 S. Ct. 1405, 1420 \& n.7 (2014) (Scalia, J., concurring) (criticizing the majority's expansive definition of "domestic violence" based on inconsistency with dictionaries and other federal statutes). It remains unclear whether Castleman imposes any relevant limitations on tribes. See also NAT'L CONG. OF AM. INDIANS, supra note 30, at 29 (noting that some tribes were not prosecuting some domestic violence crimes because they were not sure they fit within the definition set forth by Castleman).

275. NAT'L CONG. OF AM. INDIANS, supra note 30, at 5 (noting that at least two cases were referred for federal prosecution).

276. $I d$. 
convictions to federal court, but the defendants declined. Numerous parties asserted that they preferred tribal court to federal court, stating that the tribal process was less formal, less intimidating, offered more focus on treatment and showed more respect to defendants. ${ }^{277}$ Similarly, an attorney for the Pascua Yaqui tribe in Arizona notes that, "[h]istorically, people argued that tribal courts couldn't treat people fairly-but that's not a true snapshot of what tribal courts are now." He went on to note that "[t]here are a lot of tribes already doing a great job administering justice in different ways consistent with their community values." 278

Both statutes encourage alternative sentencing, and tribes employed these procedures in numerous places. At Pascua Yaqui, for example, some defendants were required to go through the culturally based Hiapsi Kuakte, or Centered Spirit, program. ${ }^{279}$ At CTUIR, all batterers, regardless whether they are Indian or not, attend intervention treatment that is provided free of charge for all defendants. ${ }^{280}$ And some prosecuting tribes remain focused on rehabilitation, rather than punishment, such as Tulalip, which has an Elders Panel and a Wellness Court, considered core to conceptions of Tulalip justice. ${ }^{281}$ Undoubtedly, incarceration is not the only model tribes utilize to punish offenders, and it will be up to each tribe to ultimately determine which crimes, if any, should be subject to an alternative program. ${ }^{282}$

277. Leonhard, supra note 86, at 21 (quoting Brent Leonhard from CTUIR's counsel office, stating that, "[c]riminal defendants in tribal courts, as compared to state and federal courts, are often treated less harshly, with more respect, and with more opportunity to tell their side of things than in other courts").

278. Allen, supra note 183 (quoting Alfred Urbina, Attorney General of the Pascua Yaqui Tribe).

279. See, e.g., Motion to Revoke Probation at 1, Pascua Yaqui Tribe v. Alvarez, No. CR-08-158 (Pascua Yaqui Tribal Ct. Jan. 5, 2009), http://www.pycourts.org/sites/default/files/filings/ trial/CR08-158-Motion-to-Revoke-Probation.pdf [https://perma.cc/88UQ-M64Z] (arguing that the court should revoke the defendant's probation, in part because the defendant did not complete the Hiapsi Kuakte).

280. Leonhard, supra note 86, at 21.

281. Tim Brewer, Attorney, Tulalip Tribes, TLOA Enhanced Sentencing: The Tulalip Experience, at 37, https://www.ncjtc.org/CONF/AIJC/Documents/Plenary\%204-Tribal \%20Law\%20and\%20Order\%20Act\%20TLOA-The\%20Tulalip\%20Experience.pdf [https://perma.cc/5HFP-NTBV].

282. Each tribe will have to come to its own conclusion to determine whether alternatives to incarceration will work in that community. See generally Laird, supra note 31 (noting that John Dossett, general counsel of the NCAI, stated that some domestic violence cases would be inappropriate for a traditional proceeding, and that he does not "think anybody's looking to use a wellness court for a severe spousal abuse case"); see also DEER, supra note 14, at 124-36 (discouraging use of peacemaking in cases of rape); Goldberg, supra note 33, at 1015-18 (cautioning against merging Indian and non-Indian dispute resolution practices); Minow, supra note 33 (recalling feminist concerns about alternative dispute resolution measures like mediations in disputes on violence and abuse). 
The analysis of recent exercises of tribal criminal authority paints a familiar picture of probation and incarceration, but leaves open the broader question whether enhanced sentencing has made Indian country safer. Again, without comparative data, there is only anecdotal evidence as to the impacts of TLOA and VAWA. But, looking closely at what those working in Indian country criminal justice are saying, their statements explicate how and why prosecutorial authority and felony sentencing make Indian country safer, beyond their implementation in any one particular case.

Those working in Indian country criminal justice repeatedly assert that the complete absence of accountability — a system where perpetrators know the probability of prosecution is incredibly low-actually encourages more crime by offenders, who know they will not be held accountable for their actions. ${ }^{283}$ Evidence suggests - in regards to domestic violence in particular- that absence of accountability for perpetrators only emboldens them. ${ }^{284}$ They escalate their crimes against their victims over time. ${ }^{285}$ Correspondingly, tribal members assert that, even when they report crimes, and those crimes are prosecuted, they are devastated by a system that can only give one year per count for even the most heinous of crimes. Thus, when Indian tribes prosecute major crimes, such as murder, but are only allowed to sentence the defendant to one year in prison under pre-TLOA ICRA limitations, tribal members lose faith in criminal justice at the tribal as well as the federal level. As a result, victims stop reporting crimes, refuse to participate in the criminal justice system, and opt out of community policing or local control altogether. This, in turn, means that more perpetrators commit repeat offenses that are never reported, thus starting the cycle over again.

The expansions represented by TLOA and VAWA, respectively, are viewed in tribes as providing an opportunity to break the cycle of violence and hopelessness in Indian country. Undoubtedly, they are only a first-and for far too many tribes, an infeasible - step towards true Indian country criminal justice reform. But if implementation allows those tribes to speak to the criminal justice issues on their reservations, they provide a glimmer of hope for seeing Indian country move in a new direction.

283. See 2008 Hearing, supra note 84, at 21 (statement of Joe A. Garcia, President, National Congress of American Indians).

284. See S. 1763, S. 872, and S. 1192: Hearing Before the S. Comm. on Indian Affairs, 112th Cong. 10 (2011) (statement of Thomas J. Perrelli, Associate Att'y Gen., U.S. Dep't of Justice).

285. See United States v. Castleman, 134 S. Ct. 1405, 1408 (2014) (noting that repeat domestic violence offenders are common, and that the violence "often escalates in severity over time"). 


\section{CONTEMPLATING THE FUTURE:A THEORY OF INDIAN COUNTRY CRIMEAND GOVERNANCE}

Sovereignty over people and territory is essential to a functioning government. The ability of tribes to arrest, prosecute, and, where necessary, punish offenders within Indian country goes to a core governmental duty. The deprivation of this right for tribes has not only been disastrous because of what it signals regarding the federal government's view of tribal sovereignty, it has been demoralizing for Indian people and Indian communities because the federal government has not picked up the mantle to fill the gaps. Because of the unique relationship between the federal government and Indian tribes, the United States has a trust responsibility to Indian tribes. ${ }^{286}$ But it is failing in that duty. ${ }^{287}$ The result, as the federal government itself concedes, is that criminal justice in Indian country is a "national disgrace." ${ }^{288}$ Accordingly, current available evidence demonstrates that tribes do, in fact, want expanded jurisdiction and authority because it suits the sovereign's prerogative theoretically as well as practically. Indian nations are governments, act as governments, and want to be treated like governments. Criminal justice authority bolsters both internal and external legitimacy and respect, in addition to providing further support for the doctrinal features discussed previously.

The fulfillment of the prerogative of tribes as sovereigns further points to other important conceptual reasons why criminal justice authority for tribes is both desired and desirable. The discussion of tribes as governments with the ability to incarcerate cannot be divorced from a larger, national conversation about crime and race. Nor can it be considered in a vacuum outside of conversations relating crime to poverty and population distribution. Coincidentally, discussions about tribal criminal jurisdiction are peaking at the same time that the national conversation regarding the failed American criminal justice system has become cacophonous. The country realizes it can no longer turn a blind eye to what is happening in the criminal justice system, and one proposed remedy for

286. See Mary Christina Wood, Indian Land and the Promise of Native Sovereignty: The Trust Doctrine Revisited, 1994 UTAH L. REV. 1471 (1994) (arguing for the continuing importance of the trust doctrine); see also Singer, supra note 15, at 1-3 (noting that the federal government has repeatedly breached its trust responsibility to Indian nations, at times under the guise of acting on their behalves).

287. See Troy A. Eid, The Tribal Law and Order Act: An "Aggressive Fight" Worth Winning, FED. LAW., Mar./Apr. 2010, at 34, 35 (citing to a speech by then-Senator Obama indicating that the United States had failed to uphold its trust responsibility to deal with criminal justice issues in Indian country).

288. 2008 Hearing, supra note 84, at 52 (quoting W. Patrick Ragsdale, Director, Office of Justice Services, U.S. Department of the Interior). 
the current system - though inciting plenty of debate-is a return to more localized policing and control. ${ }^{289}$

Led by scholars like Kevin Washburn, experts on the ground with experience with criminal justice systems have argued for decades for a return to tribally led solutions to crime control. ${ }^{290}$ In this sense, there is a timely synergy between Indian country criminal justice and the larger national conversation about criminal justice reform. Both increasingly emphasize: local control and responsibility, less federal intrusion, and more emphasis on alternatives to incarceration. In many ways, Indian tribes are the original progenitors of local, traditional and restorative justice practices, and the evidence shows tribes are eager to return to that model, at least in certain instances. ${ }^{291}$

The largely descriptive foundation of Parts I and II leads to the related normative claim of this Article. The Indian country criminal jurisdiction paradox creates a potentially impossible situation for tribes. If federal recognition of inherent tribal criminal authority only comes with greater oversight, does this mean tribes must concede sovereignty in order to gain it? Will the implementation of these laws ultimately be viewed historically as ICRA 2.0?

In this Part, I contend that, to the extent tribes are exercising the recent expansions in criminal justice authority, they should consider doing so in ways that may, in fact, depart from the authority for which they have fought. In other words, tribes are in a unique position to experience both ascension in sovereignty and a corresponding resistance to assimilation if they tread cautiously. In this moment, tribes can capitalize on expanded authority to improve conditions for Native people and enhance tribal sovereignty, while, at the same time, move further away from American models of process and punishment to experiment with criminal justice institutions more closely aligned with tribal values. This goes to a central objective of the right of self-determination; that is, not only to seek greater

289. See Stuntz, supra note 103, at 2040.

290. See Troy A. Eid \& Carrie Covington Doyle, Separate but Unequal: The Federal Criminal Justice System in Indian Country, 81 U. COLO. L. REV. 1067, 1110-16 (2010) (advocating for greater tribal control over criminal justice in Indian country); Washburn, supra note 25, at 712-15, 776-77.

291. See, e.g., Exparte Crow Dog, 109 U.S. 556 (1883) (upholding tribes' restorative justice practices in response to the murder of an Indian by another Indian, which inspired federal intervention via the Major Crimes Act); Estate of Tasunke Witko v. G. Heileman Brewing Co., 23 Indian L. Rep. 6104 (Rbd. Sx. Sup. Ct. 1996) (reversing a trial court's decision to dismiss a lawsuit in which the plaintiff pursued remedies based in restorative justice for the unlawful misappropriation of the name of the great Sioux leader, Crazy Horse). Though beyond the scope of this article, important linkages could be made between the restorative justice literature in the tribal context and that in the Anglo system. Compare Hon. Robert Yazzie, "Hozho Nahasdlii"-We Are Now in Good Relations: Navajo Restorative Justice, 9 ST. THOMAS L. REV. 117 (1996) (exploring restorative justice within the Navajo tradition and culture), with Erik Luna, Introduction: The Utah Restorative Justice Conference, 1 UTAHL. REV. 1 (2003) (entire issue devoted to restorative justice). 
autonomy within the nation-state, but to revitalize and empower indigenous justice systems to develop independently. In other words, to "decolonize" federal Indian law. ${ }^{292}$

Undoubtedly, the legacy of Western justice systems on Indian tribes has created complex dynamics within tribal communities seeking to revive tribal law and unwind the impacts of colonization. ${ }^{293}$ Nevertheless, while recognizing the enormity of this task, this Article encourages tribes to simultaneously embrace and expand their authority when possible (such as is advanced by TLOA and VAWA, respectively), while at the same time selectively depart from the American model of exceedingly harsh punishments and long sentences in favor of traditional, restorative justice models of diversion and other complementary programs, at least in some cases. ${ }^{294}$ While recognizing these two lines of thought are in some respects inconsistent, for the reasons set forth in this Article, they may be both the best and most useful strategies as tribes attempt to address current, pressing criminal justice needs, while balancing the need for long-term criminal justice reform.

There are two central rationales for this proposal. First, as an entire body of literature-and the corresponding movement-has demonstrated, the current model of American criminal justice, in which the response to crime is to continue to ratchet up sentences without thinking about corresponding treatments, services, and re-entry, is an endless cycle that only leads to defeat. Poor communities of color bear the greatest burden of this failed system. Thus, empowering tribes to go blindly down this road without careful consideration is unlikely to lead to desirable results.

292. See, e.g., Robert N. Clinton, Redressing the Legacy of Conquest: A Vision Quest for a Decolonized Federal Indian Law, 46 ARK. L. REV. 77, 121 (1993); Robert B. Porter, A Proposal to the Hanodaganyas to Decolonize Federal Indian Control Law, 31 U. MICH. J.L. REFORM 899, 904 (1998); Robert A. Williams, Jr., The Algebra of Federal Indian Law: The Hard Trail of Decolonizing and Americanizing the White Man's Indian Jurisprudence, 1986 WIS. L. REV. 219, 220-26 (1986).

293. For a series of articles on these challenges, see Matthew L.M. Fletcher, Looking to the East: The Stories of Modern Indian People and the Development of Tribal Law, 5 SEATTLE J. SOC. JUST. 1 (2006); Matthew L.M. Fletcher, Rethinking Customary Law in Tribal Court Jurisprudence, 13 MiCH. J. RACE \&L. 57 (2007); Matthew L.M. Fletcher, The Supreme Court's Legal Culture War Against Tribal Law, 2 INTERCULTURAL HUM. RTS. L. REV. 93 (2007).

294. Some cases are likely inappropriate for restorative justice processes, particularly rape and sexual assault. See DEER, supra note 14, at 125-33. Though some non-Western punishments have faced constitutional challenges in the past, most are permissible with the consent of the participating party. See generally Developments in the Law-Alternatives to Incarceration, 111 HARV. L. REV. 1863 (1998); Phaedra Athena O’Hara Kelly, Comment, The Ideology of Shame: An Analysis of First Amendment and Eighth Amendment Challenges to Scarlet-Letter Probation Conditions, 77 N.C. L. REV. 783 (1999). 
Moreover, it is entirely clear that rejection of this system is in line with Indian nations' own objectives, particularly in regards to at least some juvenile offenses, low-level offenses, or crimes involving substance abuse by tribal member defendants. The "focus on making reparations, healing victims and offenders, and restoring community" is more reflective of the "lived experience" of Native people. ${ }^{295}$ As a general matter, tribes aspire and prefer to offer an array of restorative justice options, ${ }^{296}$ but perhaps are not exploring these to the fullest extent possible.

In advancing the normative claim, this Part focuses on two central inquiries. Part III.A discusses the inextricable link between tribal sovereignty, local control, and a functioning criminal justice system. It builds off documented evidence of tribes' own desires, thereby encouraging tribes to experiment with criminal justice models that are more in line with indigenous values and that can integrate traditional tribal practices into systems of justice. Finally, Part III.B highlights ongoing challenges, explicating some of the most salient drawbacks to this entire endeavor, as well as marking some intuitive places for expansion of tribal criminal jurisdiction.

\section{A. Unexplored Opportunities: The Indian Nation as Criminal Justice Laboratory}

As this Article has shown, Indian tribes are in a double bind with respect to criminal jurisdiction. In order to secure the recognition of their sovereign rights to criminally prosecute and punish crime committed against Indians within the reservation, they must more closely emulate the American model of criminal justice. Paradoxically, then, more robust sovereign authority in this realm concomitantly forces tribes to adopt models of government that may, in fact, be assimilative at their core. The result is that tribes may further lose distinct aspects

295. INDIAN LAW \&ORDER COMM'N, supra note 9, at 131.

296. Much of the testimony around restorative justice as a preferred method in tribal communities centers on juvenile prosecutions, crimes driven directly by alcohol or drug addiction (such as public drunkenness), and select others. It is acknowledged that restorative justice may be particularly ill suited to address the crimes of domestic violence perpetrators. See DEER, supra note 14, at 124 (noting that "[t]here is no particular reason to assume . . . that restorative justice practices automatically honor women's experiences, and it would be a mistake to apply such practices to rape without rigorous interrogation"); see also Donna Coker, Enhancing Autonomy for Battered Women: Lessons From Navajo Peacemaking, 47 UCLA L. REV. 1, 8-9 (1999) (drawing from Navajo peacemaking in the domestic violence context, but recognizing its limitations); C. Quince Hopkins et al., Applying Restorative Justice to Ongoing Intimate Violence: Problems and Possibilities, 23 ST. LOUIS U. PUB. L. REV. 289, 300 (2004) (noting concerns with using restorative justice techniques in domestic violence cases). 
of culture and governance that go to the heart of nationhood, cultural survival, and tribal difference. This Part seeks to show that, while a tension undoubtedly exists, it is possible for the ascension of tribal criminal authority and tribal cultural survival to coexist and even to mutually reinforce one another.

The ILOC's Roadmap, as well as a host of other sources, concluded definitively that tribes have to be at the center of efforts to protect reservation communities. ${ }^{297}$ The federal government has proven that it simply cannot or will not provide the resources and expertise necessary to keep reservations safe. Some of these barriers are straightforward and logistical. As Kevin Washburn has demonstrated, many reservations span large swaths of remote territory, sometimes even traversing several states and time zones. ${ }^{298}$ Federal prosecutors' offices and courts can be hundreds of miles away. Communicating with witnesses, as well as convincing them to travel those distances to testify in what are often seen as "foreign" courts, is exceedingly difficult. A history of racism, abuse, and mistrust work against active participation in the criminal justice system by Indians, who often are wary of outsiders, suspicious of federal authorities they do not know, and additionally burdened by poverty and unemployment. ${ }^{299}$

Moreover, there are significant cultural gaps between tribal communities and federal policing. As Washburn refers to it, the "cavalry effect" is observed when tribal communities are largely left alone, isolated, with very little guarantee of safety, security, or justice. ${ }^{300}$ Then, when the federal government does come in to investigate a crime, it does so by descending on a reservation community to which it has no political, cultural, or social relationship. Given the complex history between tribes and the United States, tribal members are understandably wary of the federal government, even when community members are in need of law enforcement assistance. ${ }^{301}$

The argument that law enforcement in general is more effective when focused locally with significant community engagement is gaining ground in the United States. Leading criminal justice scholars have previously made the case for a return to more local control in criminal justice in the United States as a

297. See INDIAN LAW \& ORDER COMM'N, supra note 9, at 131-32; see also Washburn, Five Years of Scholarship, supra note 25, at 1029.

298. Washburn, Five Years of Scholarship, supra note 25, at 1022 (detailing expansive distances that separate tribal communities and federal courthouses, and the challenges this creates for federal prosecutors and reservation residents).

299. Washburn, American Indians, supra note 25 , at $722,727,729-40$ (detailing how the lack of resources in Indian country bears on criminal justice at the tribal and federal levels).

300. Id. at 736-38.

301. Id. 
whole. ${ }^{302}$ Setting aside whether such an approach would be beneficial nationally, based on evidence from tribal communities and the writings of experts who have worked on the ground on issues of criminal justice on reservations, there is a broad consensus that putting authority back into tribes and tribal governments will, on net, have positive benefits for safety and security on reservations. ${ }^{303}$ And, particularly relevant to this Article, a return to local control in public safety may also be especially useful to facilitate the use of alternatives to incarceration and encourage tribes to take advantage of the opportunity to experiment with new criminal justice models.

\section{Going Further: Alternatives to Incarceration}

Tribal sentiment as it pertains to restorative justice seems to be stronger than what is realized in practice. Although both TLOA and VAWA, respectively, allow for and encourage tribes to continue to implement traditional, alternative sentencing where it is appropriate, ${ }^{304}$ the tribes that have adopted the two statutes appear to be working under a fairly standard adversarial system, and probation and incarceration appear to be modeled on the federal and state systems. Although, as with the VAWA cases at Pascua Yaqui, in particular, given that the defendants were non-Indian, had no active engagement in Yaqui cultural life, and were repeat offenders, alternatives to incarceration may be particularly inappropriate. Nevertheless, while acknowledging some of the very sound reasons for tribal decisions, this Part encourages tribes-where feasible and desirable-to experiment with punishments that deviate from what is widely considered the norm in the state and federal systems.

First, I assert that extensive research shows that doing so is consistent with tribes' own preferences in both the realm of procedure, as well as with regard to questions of punishment. The ILOC's report is replete with evidence-also found within the record of consultation between tribal and federal governments regarding the implementation of TLOA — that tribes and tribal leaders

302. See Stuntz, supra note 103, at 1974.

303. See, e.g., INDIAN LAW \& ORDER COMM'N, supra note 9; Washburn, Crossroads, supra note 25, at 777; Troy A. Eid, Making Native America Safer and More Just for All Americans, HUM. RTS., Spring 2015, at 7, 25; Matthew L.M. Fletcher, Reviving Local Tribal Control in Indian Country, FED. LAW., Mar./Apr. 2006, at 38.

304. See Examining S. 797, The Tribal Law and Order Act of 2009: Hearing Before the S. Comm. on Indian Affairs, 111th Cong. 46 (2009) (statement of Troy A. Eid, Partner, Greenberg Traurig, LLP) ("Despite these concerns, Section 304 properly seeks to reinforce the critical importance of tribal courts in misdemeanor enforcement. This section could be further strengthened in two ways. First, I suggest adding language encouraging support for tribal sentencing based on the traditional and customary law of each Indian community."). 
overwhelmingly "expressed a desire for greater use of alternatives to detention in Indian country." 305 There is little doubt that traditional approaches to tribal justice- "which, echoing the Crow Dog case from long ago, focus on making reparations, healing victims and offenders, and restoring community"306 —are in line with alternatives to incarceration. Despite federal efforts at assimilation and intervention, tribes historically have employed alternative sentencing mechanisms when possible.

In the Commission's field hearings, leaders repeatedly expressed their skepticism of incarceration where other options are available. One former tribal prosecutor favorably pointed to contemporary alternatives seen in the American system - such as electronic home monitoring and work release, among others. But he most strongly advocated for culturally sensitive tribal solutions, including healing programs, sweat lodges, elders' councils, and peacemaker courts. ${ }^{307}$ Numerous leaders and tribal members echoed these views, lamenting high recidivism rates, and noting a dearth of treatment or training to reduce repeat offenses. ${ }^{308}$

Tribal sentiment in this regard has been expressed particularly strongly when addressing crimes involving juveniles. ${ }^{309}$ Tribal members have been very outspoken about removing juveniles from jails and prisons altogether. At a recent meeting regarding TLOA, tribal leaders indicated that juveniles should not be in the criminal justice system and that guidance, rather than punishment, "is more in keeping with traditional tribal practices." ${ }^{310}$ And the Commission agreed. It concluded that the most important takeaway regarding punishment was to seek alternatives to incarceration when possible, finding that they "should

305. INDIAN LAW \&ORDER COMM'N, supra note 9, at 131.

306. Id.

307. Id. at 130 (quoting Philip Harju, Tribal Attorney, Cowlitz Indian Tribe, in testimony before the Indian Law and Order Commission on November 2, 2011).

308. Id. at 134 (quoting Miskoo Petite, Staff Member, Rosebud Sioux Tribe Juvenile Detention Center, in testimony before the Indian Law and Order Commission on May 16, 2012); see also Jessica Metoui, Comment, Returning to the Circle: The Reemergence of Traditional Dispute Resolution in Native American Communities, 2007 J. DISP. RESOL. 517 (2007) (arguing that traditional dispute resolution in tribes resulted in higher rates of satisfaction for offenders and will likely reduce recidivism).

309. See 2008 Hearing, supra note 84 , at 13 (statement of Hon. Ron. His Horse Is Thunder, Chairman, Standing Rock Sioux Tribe) ("The fourth pillar in justice in Indian Country is this: alternative treatments for juveniles. You just can't simply lock them up ....”); Tanya H. Lee, Tribal Law and Order Act Five Years Later: What Works and What Doesn't, INDIAN COUNTRY TODAY (Mar. 8, 2016), http://indiancountrytodaymedianetwork.com/2016/03/08/tribal-law-and-order-act-fiveyears-later-what-works-and-what-doesnt-163670 [https://perma.cc/52JV-P39T] (noting that there was "a seeming universal commitment to keeping kids out of the justice system" among the federal and tribal leaders that attended a TLOA implementation meeting).

310. Lee, supra note 309. 
be the paramount objective in any plan to address the corrections aspect of public safety in Tribal nations." 311 The Commission noted, as did many of the speakers and participants, that many Indian offenders "are suffering the effects of poverty, isolation and substance abuse" and that "[d]etention of Tribal members should be a rare exception in the corrections context." 312

Tribes want to employ more traditional remedies-which might even alleviate the need for some of the costs associated with adversarial systems and incarceration-but it is very difficult to get funding for them. ${ }^{313}$ The ILOC echoed the frustration shared by tribes that there are so few programs in existence, and even these are threatened. ${ }^{314}$ A review of many successful programs inside and outside Indian country points to the reasons. As the ILOC found in its research, positive outcomes from alternatives to detention programs depend on having a whole host of pieces in place. In addition to money, an enormous amount of human resources, plus extensive cultural knowledge and expertise, are required. Tribes need qualified judges; a legal code that contemplates and operationalizes an alternative sentencing model; complex screening mechanisms to divert appropriate offenders but ensure incapacitation when required; strong probation or community oversight; and an "array of services" that will aid in avoiding recidivism. ${ }^{315}$

Past practice tells us that indigenous alternatives in tribal communities can flourish where tribes have the resources to implement them. The Navajo Peacemaker Court has long stood as a model. The Court is limited to non-lawyers, and the process is based on community restoration processes led by a peacemaker. The ILOC report also highlights a few of the other leading programs, including the Leech Lake Band of Ojibwe Joint Jurisdiction Wellness Court and Tulalip Tribes Alternative Sentencing Program. ${ }^{316}$ As the ILOC found, "[s]uch approaches have worked well for decades, if not centuries, and hold tremendous promise for adjudicating more disputes at less cost and for determining sentences where, based on community norms and mores, the punishment fits the crime."317

311. INDIAN LAW \& ORDER COMM'N, supra note 9, at 131 (citing U.S. DEP'T OF JUSTICE \& U.S. DEP'T OF INTERIOR, TRIBAL LAW AND ORDER ACT: LONG TERM PLAN TO BUILD AND ENHANCE TRIBAL JUSTICE SYSTEMS 10 (2011), https:/www.justice.gov/sites/default/ 312. Id. files/tribal/legacy/2014/02/06/tloa-tsp-aug2011.pdf [https://perma.cc/7ZKS-SVRA]).

313. See Creel, supra note 68 , at 357.

314. INDIAN LAW \&ORDER COMM'N, supra note 9, at 133.

315. Id.

316. Id.

317. Id. 
While alternatives to incarceration may be less relevant options for the punishment of outsiders, tribes nevertheless demonstrate, at least in some instances, a desire to take the same approach with non-Indian perpetrators as with Indians. Recall that for a tribe to exercise VAWA jurisdiction over a nonIndian, the defendant must have deep ties to the community. With increased intermarriage between Indians and non-Indians, even in Indian country, support for Native families may, in some instances, motivate tribes to attempt to rehabilitate and allow the return of non-Indian offenders. At CTUIR, for example, with 46 percent of the tribal population being non-Indian, the tribe is motivated to provide restorative justice or diversion services to non-Indians as well as Indians. In fact, one of the first domestic violence offenders to take advantage of a tribe's offender treatment program was a non-Indian. ${ }^{318}$

And integrating tribal practices into criminal justice systems is not limited to the punishment phase of the proceedings. In fact, traditional methods of adjudicating claims also influence process. Tribes have historically expressed skepticism around various procedural features of the American criminal justice system. Throughout Indian country, disputes are resolved in justice systems of many varieties, some of which may significantly deviate from American-style courts. Tribes may resolve disputes through informal mechanisms, such as families, clans, talking circles, or elder councils. ${ }^{319}$ Tribal leaders have in the past opposed the idea of jury trials, the encouragement of defendants not to speak as to their own guilt or innocence, and an impartial judge with no knowledge of the case, among others. ${ }^{320}$ Tribes may, therefore, elect to integrate traditional practices at all stages of the criminal justice process.

Despite the enthusiasm for alternatives to incarceration, leaders and policymakers at the tribal, state, and federal levels all agree that there are certain crimes that are best handled within the federal and state adversarial court system. The ILOC, too, concluded that many of the cases arising on reservations should be handled in an adversarial process, where incarceration may be the appropriate

318. See Leonhard, supra note 86, at 21 ("Many of the services the CTUIR provides, it provides to any community members regardless of tribal membership, including the services of the Family Violence Program."); NINC2004, supra note 188, at 10:30.

319. See, e.g., Nell Jessup Newton, Tribal Court Praxis: One Year in the Life of Twenty Indian Tribal Courts, 22 AM. InDiAn L. REV. 285, 309 (1998) (quoting Rave v. Reynolds, 23 Indian L. Rep. 6150, 6158 (Winnebago Sup. Ct. 1996)) (describing Winnebago dispute resolution through "family, clan, or council deliberations").

320. See U.S. COMM'N ON CIVIL RIGHTS, supra note 172, at 8-11 (citing Rights of Members of Indian Tribes: Hearing Before the Subcomm. on Indian Affairs of the Comm. on Interior and Insular Affairs on H.R. 14419 and Related Bills, 90th Cong. 127-28 (1968)) (noting the testimony of Hopis regarding right against self-incrimination, Pueblos regarding jury trials, and Navajos regarding impartial judges). 
result to remove perpetrators from the community. This is particularly true of violent felonies, including rape, sexual assault, child molestation, and domestic violence. $^{321}$

What we are witnessing in Indian country criminal justice is the "indigenization of modernity"; ${ }^{322}$ that is, where tribes seek to take the best of the Western model while still focusing on tribal laws, traditions, and values. ${ }^{323}$ Such an approach allows tribes to utilize those aspects of a contemporary system that map onto historical values and beliefs. Ample evidence demonstrates that tribes will continue to adapt and evolve tribal institutions, but in a way that reflects core tribal values. By seeking this "cultural match" between core tribal infrastructure and contemporary governance, the chances of success - in terms of economics, health, safety, welfare, and well-being-increase dramatically for tribes. ${ }^{324}$

\section{Focusing on Root Causes}

Many American Indians in the criminal justice system, like many others in the state and federal systems, are there because of addiction. Drug and alcohol abuse has been notoriously high in Indian country historically, and it has been on the rise in recent years. ${ }^{325}$ Those working in Indian country criminal justice see the devastating effects of decades of hurt and oppression, which manifests in unhealthy lifestyles on the reservation. In addressing the need for alternatives to incarceration and treatment, one tribal Chairman stated that 97 percent of all calls to police are for either domestic violence or drunk driving. ${ }^{326}$ Another

321. INDIAN LAW \& ORDER COMM'N, supra note 9, at 129-33.

322. Rosemary J. Coombe, Protecting Traditional Environmental Knowledge and Nerw Social Movements in the Americas: Intellectual Property, Human Right, or Claims to an Alternative Form of Sustainable Development?, 17 FLA. J. INT'L L. 115, 132-33 (2005) (crediting anthropologist Marshall Sahlins with coining the phrase "indigenization of modernity," meaning indigenous peoples' attempt to retain traditional ways while using tools of modern world).

323. See generally Máximo Langer, From Legal Transplants to Legal Translations: The Globalization of Plea Bargaining and the Americanization Thesis in Criminal Procedure, 45 HARV. INT'L L.J. 1 (2004) (analyzing American influence on foreign legal systems).

324. See Stephen Cornell \& Joseph P. Kalt, Two Approaches to Economic Development on American Indian Reservations: One Works, the Other Doesn't, 2006, at 12-18, https://nnidatabase.org/db/ attachments/text/JOPNAs/2005_CORNELL_kalt_JOPNA_twoapproaches.pdf [https://perma. cc/S72E-AQB6] (describing "nation-building" approach to economic development as consisting of five primary characteristics, including "cultural match," which requires strong degree of matching between "formal governing institutions and contemporary indigenous ideas").

325. See HAGAN, supra note 69 , at 122 (noting that, even in the nineteenth century, the crime Indians were most frequently punished for was probably "drunkenness").

326. INDIAN LAW \& ORDER COMM’N, supra note 9, at 130 (quoting Ivan Posey, Chairman, Eastern Shoshone Tribe on the Wind River Indian Reservation, in his testimony before the Indian Law and Order Commission on May 16, 2012). 
leader at a recent meeting of tribal and federal leaders discussing the impacts of TLOA similarly noted that 80 percent of those incarcerated are substance abuse offenders, and that this is the trend throughout Indian country. ${ }^{327}$

Though communities obviously vary, there is a general sense that drug and alcohol addiction - and alcohol, in particular-drives crime on the reservation. High rates of alcohol consumption are linked to the experience of colonialism, which has produced a great deal of the "misery and crime in Indian country." Federal policies, with a focus on domination and subordination, have led to "economic, social, and political marginalization within once healthy and selfsustaining Indian nations." From all of this comes feelings of hopelessness, frustration, helplessness, and despair-all of which fuel drug and alcohol abuse and contribute to feelings of anger and, ultimately, violent behavior. ${ }^{328}$

These problems, of course, are unique in the way they play out in Indian country, but they are not unique to American Indian communities. Similar parallels could be drawn to numerous other minority communities in the United States, each with its own particular history. While all the country's problems cannot be solved in an instant - and mostly certainly not through the criminal justice system - there are steps that tribes could take to push back against this trend. One avenue would be for tribes to lobby as hard for funding for alternatives to incarceration and treatment as they have for expanded jurisdiction and sentencing authority. Though anecdotal, there is a sense that tribes would readily employ more alternatives to the adversary model if they were funded, but many federal grants or programs are linked directly to existing carceral systems. ${ }^{329}$ Another avenue is to emphasize the disproportionate burden that Indian juveniles face. ${ }^{330}$ Because of the jurisdictional scheme, many Indian juveniles end up in federal prison, which is ill equipped to serve the needs of

327. See Lee, supra note 309.

328. INDIAN LAW \& ORDER COMM'N, supra note 9, at 131 n.37 (arguing that American Indian polices, including "ejection from ancestral lands, confinement on reservations, armed reprisal, disruption of traditional lifestyles, ongoing competition for lands, theft of natural resources, suppression of Native religious practices, involuntary fostering and adoption arrangements for children or their forced attendance at distant boarding schools, prohibition of Tribal language use, and management of all aspects of Indian people's lives by local 'Indian agents' of the U.S. government" have created "intergenerational" and "historical trauma." Quite simply, "those who have been exposed to violence tend to perpetuate violence, harming themselves, their families, and their communities"); see also Teresa Evans-Campbell, Historical Trauma in American Indian/Native Alaska Communities: A Multilevel Framework for Exploring Impacts on Individuals, Families, and Communities, 23 J. INTERPERSONAL VIOLENCE 316 (2008); Historic Trauma May Be Causing Today's Health Crisis, PBS: INDIAN COUNTRY DIARIES (Sept. 2006), http://www.pbs.org/ indiancountry/challenges/trauma.html [https://perma.cc/CL5A-4FLB].

329. 25 U.S.C. $§ 1302(\mathrm{~d})(1)(\mathrm{B})$.

330. See INDIAN LAW \& ORDER COMM'N, supra note 9, at 149-80. 
youth. Procuring funding for programs that focus on juveniles would also serve at least to begin to break the cycle of substance abuse and the suicide crisis seen in reservation communities.

Finally, as the ILOC and ample evidence from Indian country demonstrate, the most functional Indian country criminal justice systems are those where the sovereigns work together. Through a variety of avenues-interjurisdictional arrangement, cross-deputization of officers, Special Assistant U.S. Attorneys, among a host of other options - tribes are able to work directly with other sovereigns to share the burdens of criminal justice. ${ }^{331}$ Cooperation among sovereigns is key to success and could be further encouraged and provided for through better training, funding, and federal oversight.

\section{B. Ongoing Challenges}

There are numerous reasons to be skeptical of tribal adoption of TLOA or VAWA, as well as any other potential expansion of tribal criminal jurisdiction that copies the American model. This Part lays out some of the biggest concerns regarding expansions of criminal justice authority for tribes.

\section{Holding the Federal Government Accountable}

The most salient critique of the tribe-centered model that has been advocated through TLOA and VAWA is that it lets the federal government off the hook too easily. That is, the federal government is shifting authority through legislation to tribes without concomitantly shifting the resources to make those justice systems functional. ${ }^{332}$ There has been bridge funding and pilot projects for federally funded imprisonment, but they are finite and not guaranteed. The situation

331. See Oversight Hearing on Law Enforcement in Indian Country: Hearing Before the S. Comm. on Indian Affairs, supra note 25, at 1-3 (testimony of Kevin Washburn arguing for more cooperative law enforcement agreements between federal and tribal police to better police Indian reservations).

332. See Statement of the Michigan State University College of Law Indigenous Law and Policy Center on the Tribal Law and Order Act 1 (Nov. 10, 2011), http://www.aisc.ucla.edu/iloc/_files/ msu\%20ilpc\%20statement\%20to\%20the\%20indian\%20law\%20and\%20order\%20commission.pdf [https://perma.cc/6WX2-Z62Q] (noting that tribes that have the most serious crime rates are the ones that will be least likely to implement the TLOA); see also Law Enforcement in Indian Country: Hearing Before the S. Comm. on Indian Affairs, supra note 25, at 27-29 (quoting Chairman Dorgan, who comments that even with increased funding, law enforcement and corrections would still be immensely understaffed by half of their needs); S. REP. NO. 111-93, at $3 \&$ n.10 (2009), http://www.narf.org/nill/resources/TOLASenateReport.pdf [https://perma.cc/25YM-L85T] (listing the ways in which the Tribal Law and Order Act "will improve the efficiency and effectiveness of the justice system on Indian lands," but "acknowledg[ing] that the system continues to suffer a lack of consistent funding"). 
of criminal justice in Indian country is the result of decades of federal policy that has failed Native people. If the federal government were doing its part to protect Indian people, the kinds of laws that tribes have advocated for may not be necessary. And, more importantly, if the new laws change the baseline for tribal authority and the federal government correspondingly backs off, what will happen to those tribes that simply cannot afford to provide these services? Will the federal government point to changes in the law and the 'options' for tribes to further diminish their own role and responsibility?

As a report from the Indigenous Peoples Law and Policy Program at Michigan State University pointed out, because the programs are unfunded, the tribes that need them the most will not receive them. As the report states, "The terrible irony of TLOA is that the American Indian reservations with the worst crime problem are the same reservations that do not have the structural capacity to implement the Act." ${ }^{333}$ In fact, if one examines the crime rates—and particularly the rates of domestic violence- both in Alaska and in the northern Plains, it becomes apparent that the poorest, most vulnerable tribes will largely go unprotected by these statutory changes. ${ }^{334}$ The Tribal Chairman of the Cheyenne River Sioux Tribe recently reiterated the point that TLOA has not improved criminal justice on that reservation, because it cannot be implemented for lack of funding. ${ }^{335}$

Costs stand as the greatest barrier to making any kind of meaningful change in criminal justice in Indian country. Tribes contemplating VAWA report that a lack of resources is the primary reason they have not implemented the laws. ${ }^{336}$ And the costs come in many forms. For implementation alone, tribes must amend their codes and modify their procedures. ${ }^{337}$ It may also be necessary to change the tribal constitution, which can be a time-consuming and expensive process. It likely will be necessary for tribes to hire lawyers and consultants, as well as pay current staff more to spend time to walk their communities through change and to achieve community buy-in. For small tribes in particular, this could take valuable human resources that could potentially be spent on other

333. Statement of Michigan State University College of Law Indigenous Law and Policy Center on the Tribal Law and Order Act, supra note 332.

334. See INDIAN LAW \& ORDER COMM'N, supra note 9, at 33-61 (explaining some of the unique barriers to justice faced by Alaska Natives, and providing some solutions to the criminal justice problem).

335. See Lee, supra note 309.

336. NAT'LCONG. OF AM. INDIANS, supra note 30 , at 30.

337. See FOLSOM-SMITH, supra note 83, at 7 (noting that the process of amending the Rules of Court and drafting and adopting a new criminal code took over two years for the Salt River Pima Maricopa Indian Community). 
things. It also requires tribes and tribal communities to contemplate how and to what extent they want a wholesale adoption of Western law. ${ }^{338}$

An additional cost that is almost certain to arise in some form is through litigation. Numerous provisions of the statutes are vague, and there are likely to be legal challenges on many fronts. ${ }^{339}$ Some senators that opposed VAWA have boldly expressed confidence, for example, that once the law is challenged in federal court, it will not withstand constitutional scrutiny. ${ }^{340}$ If that is the case, tribes will have to confront the possibility of putting a great deal of resources into a plan that may only be struck down by the Supreme Court in the next decade. ${ }^{341}$

Thus, I advocate for dual strategies, proceeding in parallel. Tribes should do what they can now and simultaneously push harder for federal accountability going forward. Without question, the federal government has to be a partner with tribal governments in addressing crime control. It is not acceptable or feasible to think that newly enacted federal laws can successfully hand off the burden of criminal justice to Indian tribes, particularly when the systems are wholly unfunded. Based on its trust responsibility to tribes, and its historical role in dismantling tribal systems that existed previously, any efforts by the federal government to change Indian country criminal justice should come hand in hand with training, funding, support, and partnership with tribal nations. ${ }^{342}$

338. See id. at 8 (noting that the Hopi tribe ultimately decided to adopt the entire Federal Rules of Evidence and Procedure to ensure immediate familiarity for any federal judge potentially hearing appeals from the tribal court).

339. See, e.g., id. at 7 ("TLOA states, in part, that the judge handling cases that are eligible for enhanced sentencing must be 'licensed to practice law by any jurisdiction in the United States.' The lack of definitive guidance on phrases such as 'any jurisdiction' has led to multiple interpretations in the field. One jurisdiction could choose to interpret the language as requiring a state licensed attorney in the position, whereas another jurisdiction might interpret that to mean a tribally licensed attorney. The widely accepted interpretation of this language suggests that the judge could be licensed by the tribe only and there is no strict requirement that the judge be licensed by any jurisdiction." (quoting 25 U.S.C. $\$ 1302$ (c)(3)(b))).

340. See Tribal Justice: Prosecuting Non-Natives for Sexual Assault on Reservations, supra note 215 (quoting Senator Tom Coburn).

341. Indian tribes fare notoriously poorly before the U.S. Supreme Court, with a record that is worse than that of convicted criminals. See Getches, supra note 166, at 280 ("Tribal interests have lost about $77 \%$ of all the Indian cases decided by the Rehnquist Court in its fifteen terms, and $82 \%$ of the cases decided by the Supreme Court in the last ten terms."); see also ROBERT A. WILLIAMS, JR., LIKE A LOADED WEAPON: THE REHNQUIST COURT, INDIAN RIGHTS, AND THE LEGAL HISTORY OF RACISM IN AMERICA (2005) (discussing Rehnquist's particularly destructive record on Indian rights and its long-term consequences); Matthew L.M. Fletcher, The Supreme Court's Indian Problem, 59 HASTINGS L.J. 579, 591 (2008).

342. It is beyond the scope of this Article to lay out a plan for funding tribal criminal justice systems across the United States, but one compelling funding plan has been set forth by the ILOC's Roadmap. 


\section{Clarifying Arrest Authority}

Despite the fact that tribal police officers are peace officers and have the authority to detain an offender and "transport him to the proper authorities,"343 there is confusion among tribal police officers as to the scope of this power. Diane Millich's powerful story highlights the incredibly complex jurisdictional questions that arise in the course of Indian country criminal justice. And, although the issue should be treated as well settled, confusion remains. There is some evidence that the Bureau of Indian Affairs itself is training tribal police officers and instructing them that they lack the authority to arrest and detain perpetrators until they can be turned over to the correct sovereign with jurisdiction. ${ }^{344}$ This creates a severe detriment to public safety in Indian country. The testimony from the legislative history of VAWA itself revealed incidents where abusers flagrantly abused victims, taunting them that the tribal police could do nothing to intervene. ${ }^{345}$ And often, they were right.

Tribal police are often the first responders to crimes occurring on Indian reservations. But, as Former Associate Attorney General Tom Perrelli testified before the Senate Committee on Indian Affairs prior to reauthorization of VAWA, tribal police are in an incredibly difficult position. Imagine, for example, in a pre-VAWA world, where tribal police officers respond to a domestic violence call on the reservation. Upon arrival, they ascertain the perpetrator is non-Indian, or they are unsure of his identity. As Perrelli puts it, these officers often mistakenly believe they cannot even make an arrest. Thus, failing to intervene means that abusers increase and escalate their attacks, which is quite common, particularly in domestic violence situations. Victims are also then deterred from reaching out to law enforcement in the case of future incidents. ${ }^{346}$

Perrelli refers to the beliefs of tribal police as "mistaken," but the reality is that tribal officers' fears are not wholly unfounded. In recent years, there have

343. Duro v. Reina, 495 U.S. 676, 697 (1990).

344. See Letter From Jefferson Keel, President, Nat'l Cong. of Am. Indians, to Kevin Washburn, Assistant Sec'y for Indian Affairs, U.S. Dep't of Interior, and Hilary Tompkins, Solicitor, U.S. Dep't of Interior 1 (July 24, 2013), http://www.tribal-institute.org/download/VAWA/ NCAI\%20Washburn-Tompkins\%20letter_\%20arrest\%20authority_071013.pdf [https://perma. $\mathrm{cc} / \mathrm{S} 4 \mathrm{Q} 8$-YX8G] (requesting clarification on authority of tribal law enforcement to detain and arrest non-Indians).

345. See 160 CONG. REC. 26, S942 (Feb. 12, 2014).

346. See S. 1763, S. 872, and S. 1192: Hearing Before the S. Comm. on Indian Affairs, supra note 284; Statement of Associate Attorney General Thomas J. Perrelli Before the Committee on Indian Affairs on Violence Against Native American Women, U.S. DEP’T JUST. (July 14, 2011), https://www. justice.gov/opa/speech/statement-associate-attorney-general-thomas-j-perrelli-committeeindian-affairs-violence [https://perma.cc/7P2A-9DDJ]. 
been reports of instances in which tribal police have actually faced intimidation or criminal sanctions themselves for acting as peace officers. Recently, a non-Indian violated a protection order on a reservation in California. The tribal police arrested the offender and the tribal police were subsequently prosecuted for restraining and detaining the non-Indian violator. The prosecution still has not been dropped. ${ }^{347}$ As an attorney for the tribe argued, this state of affairs leaves tribal police officers impotent and fearful of doing their jobs when they are at risk of prosecution. ${ }^{348}$ There are similar reports that Nevada tribes have been questioned about their authority to arrest non-member Indians, an issue that already came before the Supreme Court and was definitively decided in United States v. $\mathrm{Lara}^{349}$ upholding tribes' inherent authority to exercise criminal jurisdiction over all Indians within its territory, regardless of membership status. ${ }^{350}$

Leaving arrest authority as an open question has a profoundly negative impact on Indian tribes. First, it disincentivizes individuals from becoming tribal police officers and creates a culture where tribal police are reluctant to respond to protect victims, even in exigent circumstances. Self-determination and sovereignty require, at a minimum, that tribal police officers be empowered to act as peace officers without fear of prosecution or retaliation, at least until perpetrators can be turned over to the proper authority. The federal government is simply not available to cover the duties of local policing. The National Congress of American Indians (NCAI) has requested from DOI that the scope of arrest authority of tribal police officers be definitively clarified, but that has yet to happen.

The murkiness of arrest authority is even more problematic if considered in the context of tribes' SDVCJ under VAWA. A hypothetical example posited by NCAI demonstrates why it is so important that the arrest authority of Indian tribes be clarified. When out on a domestic violence call, tribal police must act quickly. Imagine the following scenario:

[A] tribal police officer arrives at a crime scene potentially involving domestic violence, alcohol, drugs, weapons, and the safety of children

347. See Bishop Paiute Tribe v. Inyo County, No. 1:15-CV-00367-GEB-JLT, 2015 WL 4203986 (E.D. Cal. July 13, 2015) (dismissing the tribe's case against the county, but taking no action on the criminal prosecution against the tribal police officer); BHdesign15, Bishop Paiute Tribe Case Against Inyo County, the Inyo County Sheriff and District Attorney Is Dismissed, CAL. INDIAN LEGAL SERVS. (July 16, 2015), http://www.calindian.org/bishop-paiute-tribe-case-against-inyo-county-the-inyocounty-sheriff-and-district-attorney-is-dismissed-2/ [https://perma.cc/F9NF-F6FJ].

348. See Elizabeth Warmerdam, Judge Tosses Tribe's Case Against Sheriff, COURTHOUSE NEWS SERV. (July 16, 2015), http://www.courthousenews.com/2015/07/16/judge-tosses-tribes-case-againstsheriff.htm [https://perma.cc/2T2P-PER8] (quoting Dorothy Alther, Executive Director, California Indian Legal Services).

349. 541 U.S. 193 (2004).

350. Id. at 210 . 
and bystanders. The police officer likely will not be able to rapidly and accurately make a determination if the perpetrator is Indian or nonIndian - and if non-Indian, then if he is married to the Indian victim, or subject to a protective order, or in a "social relationship of a romantic or intimate nature ... as determined by the length of the relationship, the type of relationship, and the frequency of interaction between the persons involved .... ."351

Given all the ways in which the federal government has abandoned Indian reservations in terms of providing basic policing services, it is untenable that tribal police are sent on patrol without clear authority to arrest and detain without fear of prosecution themselves. The current system creates perverse incentives, and actually encourages tribal police to ignore scenarios in which they cannot confirm either the race or membership of the perpetrator or where they cannot assess in a potentially violent and dangerous scenario what the terms of the relationship are between the perpetrator and the victim(s).

Without a complete Oliphant fix-in which tribes would have complete territorial criminal jurisdiction, regardless of who was committing the crimeor a local police presence filled, or funded, by the federal government, there must be some other creative solution to solve the problem of arrest authority. In addition to increased calls to the Secretary of Indian Affairs for clarification, tribes may also look for other options, such as more comprehensive intergovernmental agreements with surrounding sovereigns. For many tribes, this has served as the cornerstone of the most functional policing system, allowing cooperation between sovereigns who can work together, pool resources, and make a dent in the current crime epidemic. ${ }^{352}$

\section{Expanding VAWA's Reach}

While tribes continue to contemplate steps forward, those that have implemented VAWA, in particular, have demonstrated specific ways in which the law does not go far enough. A natural offshoot of theories linking sovereignty and criminal jurisdiction is the repeated call from tribes to see an increase in the scope of VAWA-style jurisdiction to handle "collateral crimes." One of the greatest ironies of the reauthorization of VAWA with the tribal provisions has been that the movement toward change was motivated, in part, by the Amnesty

351. See Letter From Jefferson Keel, to Kevin Washburn and Hilary Tompkins, supra note 344, at 2 (quoting 25 U.S.C. § 1304(a)(1) (2014)).

352. See Matthew L.M. Fletcher, A Unifying Theory of Tribal Civil Jurisdiction, 46 ARIZ. ST. L.J. 779, 816-17 (2015) (discussing the efficacy of intergovernmental agreements in crime control). 
International report and other documented evidence of rampant sexual violence again Indian women in Indian country. But VAWA does not address cases of sexual assault or rape when the non-Indian perpetrator is a stranger to the reservation..$^{353}$

Likewise, the pilot project tribes have articulated a desire for authority to charge crimes committed against child victims and other collateral crimes as well. ${ }^{354}$ Child abuse has been a particular source of concern, as statistics and common sense bear out that children commonly are present during crimes of domestic violence. In fact, all three of the pilot project tribes reported that children are commonly victims or witnesses to domestic violence. ${ }^{355}$ In one extreme instance, a non-Indian boyfriend, who was on a three-day long methamphetamine bender, forced his Indian girlfriend and her child to sit in a chair while he threw knives at them. Although the tribe could prosecute the non-Indian perpetrator for the crime against the Indian woman, it could not prosecute for the crime of child abuse. ${ }^{356}$

Unfortunately, due to all the impediments laid out in Part I, cases oftentimes are not prosecuted once they are referred to federal or state authorities. In a 2015 report, Tulalip Tribes asserted that: "Of the crimes in which children were victims of crime, only 1 case will be prosecuted because the underlying crime was transferred to federal court. The State has not taken action on other 4 crimes in which children were victims." ${ }^{357}$

Looking down the road towards increased efforts to bolster sovereignty and self-determination will require that Congress consider areas where it makes intuitive sense to ensure that tribes can prosecute for those crimes related to domestic violence charges, as well as consider other areas of expansion. If enhanced tribal criminal authority is genuinely intended to move the needle in regards to safety and security on reservations, these relatively modest changes are at least a first step towards that goal.

353. 25 U.S.C. § 1304(b)(4) (2014); see also TRIBAL LAW \& POLICY INST., supra note 140, at 31-34 (discussing the types of defendants subject to Indian jurisdiction under VAWA).

354. See Tulalip Tribes, Press Release, VAWA 2013 and the Tulalip Tribes Jurisdiction Over Crimes of Domestic Violence, TULALIP TRIBES (Oct. 5, 2015), http://www.tulaliptribesnsn.gov/Portals/0/pdf/departments/tribal_court/18380_VAWA_2013-v3_Minus_Story.pdf

[https://perma.cc/2YEN-A5CL]; see also Congressional Briefing on the Impact of VAWA 2013 in Indian Country, INDIAN L. RES. CTR. (Feb. 22, 2011), http://indianlaw.org/safewomen/ congressional-briefing-impact-vawa-2013-indian-country [https://perma.cc/93GL-ZLT6] (quoting Peter Yucupicio as saying that "VAWA jurisdiction is still limited to certain crimes, does not protect victims of stranger rape, and does not protect children or other family members").

355. NAT'LCONG. OF AM. INDIANS, supra note 30 , at 8.

356. Id. at 26 .

357. Tulalip Tribes, supra note 354. 


\section{CONCLUSION}

Ironically, in light of a national dialogue about reducing sentences and taking a different approach to policing, Indian country is moving in the opposite direction. But, instead of viewing this as a one-way ratcheting up of criminal punishments, it should be seen as making marginal progress towards leveling the playing field in regards to policing and safety in Indian country.

This Article has sought to offer a roadmap to tribes on the cusp of implementation of TLOA, VAWA, or both, and also offer insights to neighboring governments considering intergovernmental agreements with tribes. ${ }^{358}$ In addition to answering the doctrinal and theoretical questions raised, it also catalogues important data for Congress or other policymakers to consider, as they may be asked to contemplate other modifications to tribal criminal jurisdiction in the future. Today, hundreds of tribes across the United States stand on the precipice of making critical choices about whether they will opt into the enhanced sentencing of TLOA, the expanded jurisdictional reach of VAWA, both, or neither, as well as how they will operationalize these changes. The answers to these questions will impact fiscal and human resource allocation, law reform, institution building, and tribes' own exercise of sovereign authority that will touch the day-to-day lives of tribal members and those who come in contact with them.

Though there are, in some cases, enormous costs to implementation of the two laws, ultimately each tribe will have to make decisions about how to move forward. From this perspective, implementation is more than merely symbolic; it is the prerogative of a sovereign government. At the same time, with this power comes an enormous responsibility, and it will be up to each individual tribe to make determinations as to whether and to what extent they will exercise it for the future and benefit of Indian people.

358. Intergovernmental agreements and cooperation between sovereigns has been an important strategy for tribes to provide public safety. See Lee, supra note 309 (noting that coordinated efforts among law enforcement teams has helped with public safety on reservations). 